UNIVERSIDADE DE SÃO PAULO

FACULDADE DE ODONTOLOGIA

\title{
MORFOMETRIA COMPARATIVA IN VITRO DO DESGASTE DENTINÁRIO DO TERÇO CERVICAL \\ DE RAÍZES MÉSIO-VESTIBULARES DE PRIMEIROS MOLARES SUPERIORES PRODUZIDO POR INSTRUMENTOS ROTATÓRIOS DE AÇO E DE NÍQUEL-TITÂNIO
}

JÚNIO PEREIRA DE SÁ

Dissertação apresentada à Faculdade de Odontologia da Universidade de São Paulo, para obter o Título de Mestre, pelo Programa de PósGraduação em Odontologia. Área de Concentração: Endodontia. 
Data da Defesa:

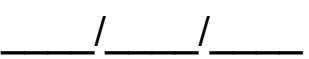

\section{Banca Examinadora}

Prof. Dr.:

Julgamento:

Assinatura:

Prof. Dr.:

Julgamento:

Assinatura:

Prof. Dr.:

Julgamento:

Assinatura:

Prof. Dr.:

Julgamento:

Assinatura:

Prof. Dr.:

Julgamento:

Assinatura: 
UNIVERSIDADE DE SÃO PAULO

FACULDADE DE ODONTOLOGIA

\section{MORFOMETRIA COMPARATIVA IN VITRO DO \\ DESGASTE DENTINÁRIO DO TERÇO CERVICAL \\ DE RAÍZES MÉSIO-VESTIBULARES DE PRIMEIROS MOLARES SUPERIORES PRODUZIDO POR INSTRUMENTOS \\ ROTATÓRIOS DE AÇO E DE NÍQUEL-TITÂNIO}

JÚNIO PEREIRA DE SÁ

Dissertação apresentada à Faculdade de Odontologia da Universidade de São Paulo, para obter o Título de Mestre, pelo Programa de PósGraduação em Odontologia.

Área de Concentração: Endodontia.

Orientador: Prof. Dr. Manoel Eduardo de Lima Machado

São Paulo 


\title{
Catalogação-na-Publicação
}

\author{
Serviço de Documentação Odontológica
}

Faculdade de Odontologia da Universidade de São Paulo

Sá, Júnio Pereira de

Morfometria comparativa in vitro do desgaste dentinário do terço cervical de raízes mésio-vestibulares de primeiros molares superiores produzido por instrumentos rotatórios de aço e de níquel-titânio / Júnio Pereira de Sá; orientador Manoel Eduardo de Lima Machado - São Paulo, 2002.

188p. : 30tab.; 5gráf.

Dissertação (Curso de Mestrado - Programa de Pós-Graduação em Odontologia. Área de Concentração Endodontia) - Faculdade de Odontologia da Universidade de São Paulo

1. Preparo Químico-Cirúrgico dos Canais Radiculares 
"Nec certam sedem, nec propriam faciem, nec munus ullum peculiare tibi dedimus, o Adam, ut quam sedem, quam faciem, quae munera tute optaveris, ea, pro voto, pro tua sententia, habeas et possideas. Definitia ceteris natura intra praescriptas a nobis leges coercetur. Tu, nullis angustiis coercitus, pro tuo arbitrio, in cuius manu te posui, tibi illam praefinies. Medium te mundi posui, ut circumspiceres inde commodius quicquid est in mundo. Nec te caelestem neque terrenum, neque mortalem, neque immortalem fecimus, ut tui ipsius quase arbitrarius honorariusque plastes et fictor, in quam malueris tute formam effingas..."

Oratio de Hominis Dignitate Giovani Pico della Mirandola (1463-1494)
"Não te dei face, nem lugar que te seja próprio, nem dom algum que te faça particular, ó Adão, a fim de que tua face, teu lugar e teus dons, tu os desveles, conquistes e possuas por ti mesmo. Natureza definida de outras espécies em leis por mim estabelecidas. Mas tu, a que nenhum confim delimita, por teu próprio arbitrio, entre as mãos daquele que te colocou, tu te defines a ti mesmo. Te pus no mundo, a fim de que possas melhor contemplar o que contém o mundo. Não te fiz celeste nem terrestre, mortal ou imortal, a fim de que tu mesmo, livremente, à maneira de um bom pintor ou de um hábil escultor, descubras tua própria forma..."

Discurso sobre a Dignidade do Homem Giovani Pico della Mirandola (1463-1494) 
"Haec testimonia animae quanto vera, tanto simplicia; quanto simplicia, tanto vulgaria; quanto vulgaria, tanto communia; quanto communia, tanto naturalia; quanto naturalia, tanto divina. Non putem cuiquam frivolum et frigidum videri posse, si recogitet naturae maiestatem, ex qua censetur auctoritas animae. Quantum dederis magistrae, tantum adjudicabis discipulae. Magistra natura, anima discipula. Quidquid aut illa edocuit, aut ista perdidicit, a Deo traditum est, magistro scilicet ipsius magistrae. Quid anima possit de principali institutore praesumere, in te est aestimare de ea quae in te est. Senti illam, quae ut sentias efficit: recogita in praesagiis vatem, in ominibus augurem, in eventibus prospicem. Mirum si a Deo data homini novit divinare. Tam mirum, si eum a quo data est, novit."

De Testimonio Animae Quintus Septimus Florens Tertullianus (160-?)
"Estes testemunhos da alma quanto mais verdadeiros, tanto mais simples; quanto mais simples, tanto mais vulgares; quanto mais vulgares, tanto mais comuns; quanto mais comuns, mais naturais; quanto mais naturais, tanto mais divinos. Não acredito que estes testemunhos possam parecer sem sentido e importância para alguém, tendo em vista que é justamente da majestade da natureza que provém a autoridade da alma. O que atribuíres à mestra, também deverás atribuir à discípula. A mestra é a natureza, a discípula, a alma. Tudo quanto a primeira ensinou ou a segunda aprendeu foi concedido por Deus, preceptor da mestra. Está em ti, a partir da alma que tens dentro de ti, julgar o quanto a alma possa receber do seu supremo mestre. Procura sentir dentro de ti a presença daquela de onde provêm as tuas sensações. Considera que ela é tua vidente nos eventos que prenunciam o futuro, tua intérprete nos vaticínios, e aquela que vela por ti nos acontecimentos posteriores. Admirável é que ela conheça Deus que concedeu aos homens tais coisas, mas mais admirável ainda é que conheça Aquele que as deu". *

O testemunho da alma Quintus Septimus Florens Tertullianus (160-?) 


\section{DEDICATÓRIA}

Aos meus pais João e Ivone que me fizeram presente a vida da qual foram os primeiros Mestres por herança e vontade e o espelho grande do caráter.

Aos meus irmãos João, Luís e Cláudio, companheiros e cúmplices de uma jornada num compartilhar claro de carinho e desvelo.

Aos meus tios Manoel e Sofia e à Aldenora.

Ao Elísio Boldo pelo carinho e pela grande amizade.

Ao Prof. Dr. Manoel Eduardo de Lima Machado pelo espírito empreendedor e pela inspiração na realização deste trabalho.

À Profa. Dra. Maria Letícia Borges Britto pelo carinho e pela solicitude que sempre me fez presentes de valor inestimável. 
Ao Isidro, ao José Oswaldo, à Rosy, ao Carlos, à Marly e ao Décio - in memorian.

À Helena, ao Paulo, à Iraci, à Eva e ao Jorge pela amizade sincera.

À Silvia Helena Buendia pela amizade sincera e pelo estímulo constante.

Aos formandos de 1983 da Faculdade de Odontologia de Araçatuba, da Universidade Estadual Paulista "Júlio de Mesquita Filho".

Aos amigos dos primeiros momentos na Universidade de São Paulo: Martinha, Priscila, Vera, Virgínia, Adriana, Noélia, Sônia e Lincohn.

Ao Cledson, Miguel, Ricardo e Patrícia.

Aos Professores e Assistentes da Disciplina de Endodontia da Faculdade de Odontologia da Universidade Camilo Castelo Branco: Arlindo, Raul, Lúcia, Newton, Massaro, Ana Lúcia, Líris, Maria Emília, Zappa e Daniel.

Aos colegas do Curso de Mestrado: Arturo, Crystiane, Cláudia, Cristina, Diana, Elce, Érico, Evandro, Marili, Paula, Rodrigo e Weber. 
A todos os pacientes que se submeteram aos meus cuidados na prática da Odontologia ou como atividade profissional ou como atividade acadêmica. 


\section{AGRADECIMENTOS}

Aos meus pais João e Ivone e aos meus irmãos João, Luís e Cláudio pelo apoio e estímulo constantes em toda vivência de natureza tanto acadêmica como profissional.

À Iraci pela dedicação e carinho em todos os momentos da vida profissional.

Ao Prof. Dr. João Humberto Antoniazzi pela receptividade e colaboração valiosas .

Ao Prof. Dr. Antônio Carlos Bombana, pela oportunidade primeira.

À amiga Helena por sua colaboração e estímulo tão fraternos.

À Universidade de São Paulo, através da Faculdade de Odontologia, por me receber como seu aluno. 
Aos Professores da Disciplina de Endodontia do Departamento de Dentística da Faculdade de Odontologia da Universidade de São Paulo: Prof. Dr. Hildeberto Francisco Pesce (in memorian), Prof. Dr. Waldocyr Simões, Prof. Dr. Carlos Eduardo Aun, Prof. Dr. Abílio Albuquerque Maranhão de Moura, Prof. Dr. José Luiz Lage Marques, Prof. Dr. Marcelo dos Santos, Prof. Dr. Igor Prokopowitsh, Prof. Dr. Giulio Gavini e Prof. Dr. Celso Luís Caldeira.

Ao Prof. Dr. Moacyr Domingos Novelli e a Secretária Sra. Luizete Pacheco e Silva da Disciplina de Patologia Oral do Departamento de Patologia da Faculdade de Odontologia da Universidade de São Paulo.

Aos funcionários da Disciplina de Endodontia do Departamento de Dentística da Faculdade de Odontologia da Universidade de São Paulo: Neuza, Luisinho, Ana Maria, Álvaro, Arnaldo, Da. Delma e David.

À bibliotecária Sra. Luzia Marilda Zoppei Murgia de Moraes pela valiosa orientação na confecção deste trabalho.

A todos os pacientes que se submeteram aos meus cuidados na prática da Odontologia ou como atividade profissional ou como atividade acadêmica. 


\title{
AGRADECIMENTOS ESPECIAIS
}

\author{
À Profa. Maria Letícia Borges Britto de Lima Machado pelo carinho \\ fraterno e por honrar-me com sua colaboração despretensiosa e de \\ inestimável valor na realização deste trabalho.
}

Ao amigo Elísio pelo apoio de valor inestimável e tão despretensioso em momentos de intranqüilidade.

Ao Prof. Dr. Manoel Eduardo de Lima Machado pela amizade, compreensão e paciência, pela orientação e pelo constante estímulo na realização da tarefa que me foi atribuída.

À amiga Silvia Helena Buendia pelo carinho e estímulo tão fraternos . 


\section{SUMÁRIO}

p.

LISTA DE TABELAS

LISTA DE GRÁFICOS

LISTA DE ABREVIATURAS E SIGLAS

LISTA DE SÍMBOLOS

RESUMO

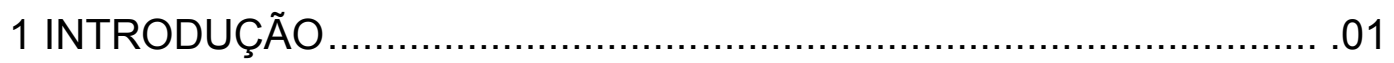

2 REVISÃO DA LITERATURA ............................................... 05

2.1 Do preparo do canal radicular ..................................................19

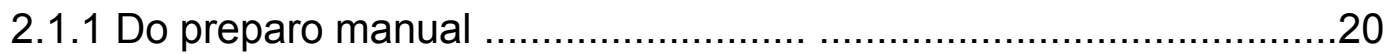

2.2 Do preparo automatizado do canal radicular ................................42

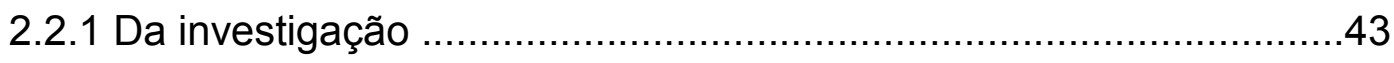

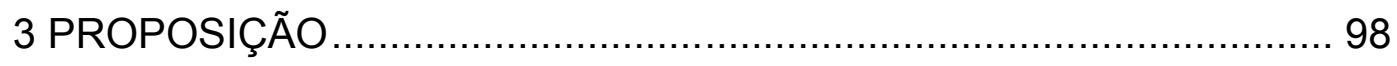

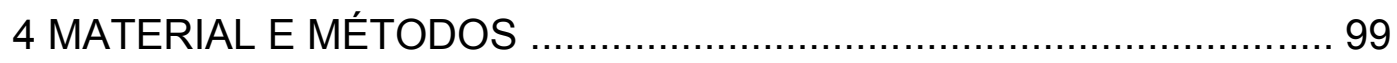

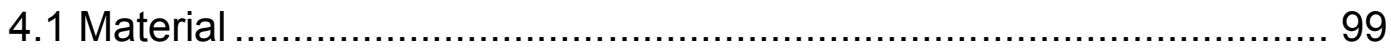

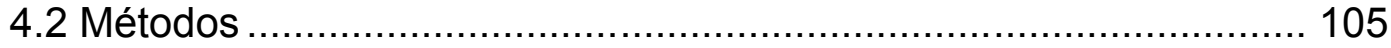

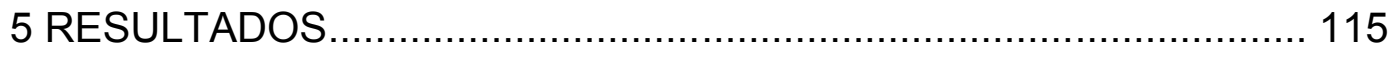

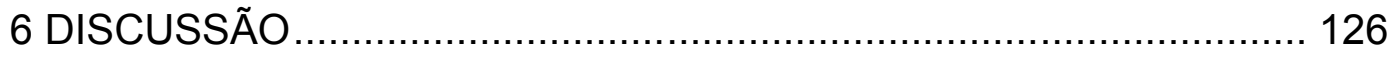

7 CONCLUSÕES ................................................................... 145

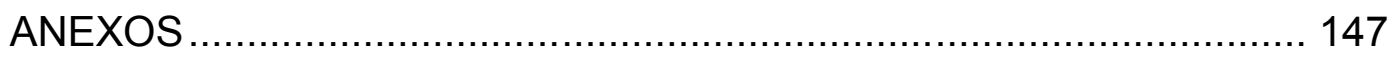

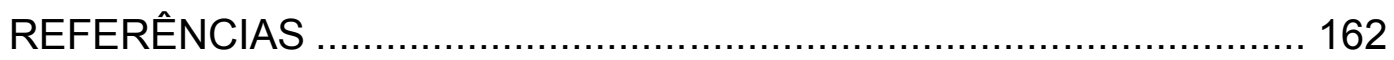

GLOSSÁRIO

SUMMARY 


\section{LISTA DE TABELAS}

Tabela $\quad A-$ Seqüência de instrumentos empregados no experimento em cada grupo experimental 110

Tabela An.A 1 - Valores originais em pixels, divididos por $10^{2}$, das áreas dos espécimes do Grupo Experimental \#1 antes e após o Preparo Químico-Cirúrgico com Brocas Gates-Glidden .142

Tabela An.A 2 - Valores originais em pixels, divididos por $10^{2}$, das áreas dos espécimes do Grupo Experimental \#2 antes e após o Preparo Químico-cirúrgico com Brocas Largo-Peeso ....142

Tabela An.A 3 - Valores originais em pixels, divididos por $10^{2}$, das áreas dos espécimes do Grupo Experimental \#3 antes e após o Preparo Químico-Cirúrgico com Profile ${ }^{\circledR} .04$ e .06 \& Orifice Shapers 143

Tabela An.A 4 - Valores originais em pixels, divididos por $10^{2}$, das áreas dos espécimes do Grupo Experimental \#4 antes e após o Preparo Químico-Cirúrgico com Pow- $\mathrm{R}^{\mathrm{TM}}$ Coronal Shapers 
Tabela An.A 5 - Valores das variações de área dos espécimes do Grupo Experimental \#1 após o Preparo Químico-Cirúrgico com Brocas Gates-Glidden 144

Tabela An.A 6 - Valores das variações de área dos espécimes do Grupo Experimental \#2 após o Preparo Químico-Cirúrgico com Brocas Largo-Peeso 144

Tabela An.A 7 - Valores das variações da área dos espécimes do Grupo Experimental \#3 após o Preparo Químico-Cirúrgico com Profile $^{\circledR} .04$ e .06 \& Orifice Shapers 145

Tabela An.A 8 - Valores das variações de área dos espécimes do Grupo Experimental \#4 após o Preparo Químico-Cirúrgico com Pow- $\mathrm{R}^{\mathrm{TM}}$ Coronal Shapers .145

Tabela An.B 9 - Teste de Normalidade das variações de área das paredes mesiais das amostras - Parâmetros amostrais 146

Tabela An.B10 - Teste de Normalidade das variações de área das paredes mesiais das amostras - Distribuição de Freqüências ....146

Tabela An.B11 - Teste de Normalidade das variações de área das paredes mesiais das amostras - Teste de Aderência

Tabela An.B12 - Teste de Normalidade das variações de área das paredes distais das amostras - Parâmetros Amostrais 148

Tabela An.B13 - Teste de Normalidade das variações de área das paredes distais das amostras - Distribuição de Freqüências 148

Tabela An.B14 - Teste de Normalidade das variações de área das paredes distais das amostras - Teste de aderência 148 
Tabela An.B15 - Teste de Normalidade das variações de área total (paredes mesial e distal) das amostras - Parâmetros Amostrais ..149

Tabela An.B16 - Teste de Normalidade das variações de área total (paredes mesial e distal) das amostras - Distribuição de Freqüências

Tabela An.B17 - Teste de Normalidade das variações de área total (paredes mesial e distal) das amostras - Teste de Aderência ......150

Tabela An.C18 - Parâmetros Amostrais segundo os grupos experimentais e paredes analisadas (valores em percentuais) 152

Tabela An.C19 - Parâmetros Amostrais das variações de área segundo as paredes analisadas

Tabela An.C20 - Teste de Homogeneidade de Bartlett das variações de área entre as amostras 153

Tabela An.C21 - Análise de Variância das variações de área das paredes mesiais das amostras .154

Tabela An.C22 - Análise de Variãncia das variações de área das paredes distais das amostras .154

Tabela An.C23 - Análise de Variãncia das variaões de área total - paredes mesial e distal - das amostras 154

Tabela An.C24 - Valor calculado de F para análise das médias das amostras 154

Tabela An.C25 - Teste de Tukey das variações de área entre as amostras para $\alpha=5 \%$ 155 
Tabela An.C26 - Valor calculado de q para a comparação das médias das amostras 155

Tabela An.C27 - Valores das diferenças das médias das amostras para a parede mesial 155

Tabela An.C28 - Valores das diferenças das médias das amostras para a parede distal 155

Tabela An.C29 - Valores das diferenças das médias das amostras para as paredes mesial e distal 156 


\section{LISTA DE GRÁFICOS}

Gráfico An.B1- Variação de área das paredes mesiais nas amostras 147

Gráfico An.B2- Variação de área das paredes distais nas amostras 149

Gráfico An.B3- Variação de área total - parede mesial e parede distal - nas amostras 150

Gráfico An.B4- Percentual de paredes vs. Maior desgaste por amostra ...151

Gráfico An.C5 - Médias de desgaste por amostra 156 


\section{LISTA DE ABREVIATURAS E SIGLAS}

\begin{tabular}{|c|c|}
\hline A.C. & antes de Cristo \\
\hline ADA & American Dental Association \\
\hline An. & anexo \\
\hline ANOVA & Analyze of Variance - Análise de Variância \\
\hline $\mathrm{CC}$ & centímetro cúbico \\
\hline CFS & Canal Finder System \\
\hline $\mathrm{cm}$ & centímetro(s) \\
\hline Co. & Company \\
\hline CRT & Comprimento Real de Trabalho \\
\hline CS & Coronal Shapers \\
\hline ed. & edição \\
\hline EDTA & Ácido Dietilamimnotetracético \\
\hline e.g. & exempli gratia - por exemplo \\
\hline et al. & et alii - e outros, e colaboradores \\
\hline etc. & et cetera - e outros, e assim por diante \\
\hline EUA & Estados Unidos da América do Norte \\
\hline fig. & figura \\
\hline G & Grupo Experimental \\
\hline
\end{tabular}




$\begin{array}{ll}\text { G1 } & \text { Grupo Experimental \#1 } \\ \text { G2 } & \text { Grupo Experimental \#2 } \\ \text { G3 } & \text { Grupo Experimental \#3 } \\ \text { G4 } & \text { Grupo Experimental \#4 } \\ \text { h } & \text { hora(s) } \\ \text { HA } & \text { instrumento endodôntico Helioapical } \\ \text { I } & \text { elemento químico lodo } \\ \text { i.e. } & \text { id est - isto é, quer dizer } \\ \text { Inc. } & \text { Incorporated } \\ \text { ISO } & \text { International Standard Organization } \\ \text { Jr. } & \text { Junior } \\ \text { LASER } & \text { Light Amplification by Stimulated Emission of Radiation } \\ \text { Ltd. } & \text { Limited } \\ \text { Ltda. } & \text { Limitada } \\ \text { MAs } & \text { miliamperes } \\ \text { MEV } & \text { Microscopia Eletrônica de Varredura } \\ \text { mHz } & \text { megaHertz } \\ \text { Ml } & \text { Michigan } \\ \text { min } & \text { minuto } \\ \text { NiTi } & \text { Níquel-Titânio } \\ \text { Nitinol } & \text { acrônimo de Nickel-Titanium e Naval Ordnance Laboratory } \\ \text { mm } & \text { milímetro } \\ \text { mod. } & \text { modelo } \\ \text { estat:: não significante } \\ \text { Ms }\end{array}$




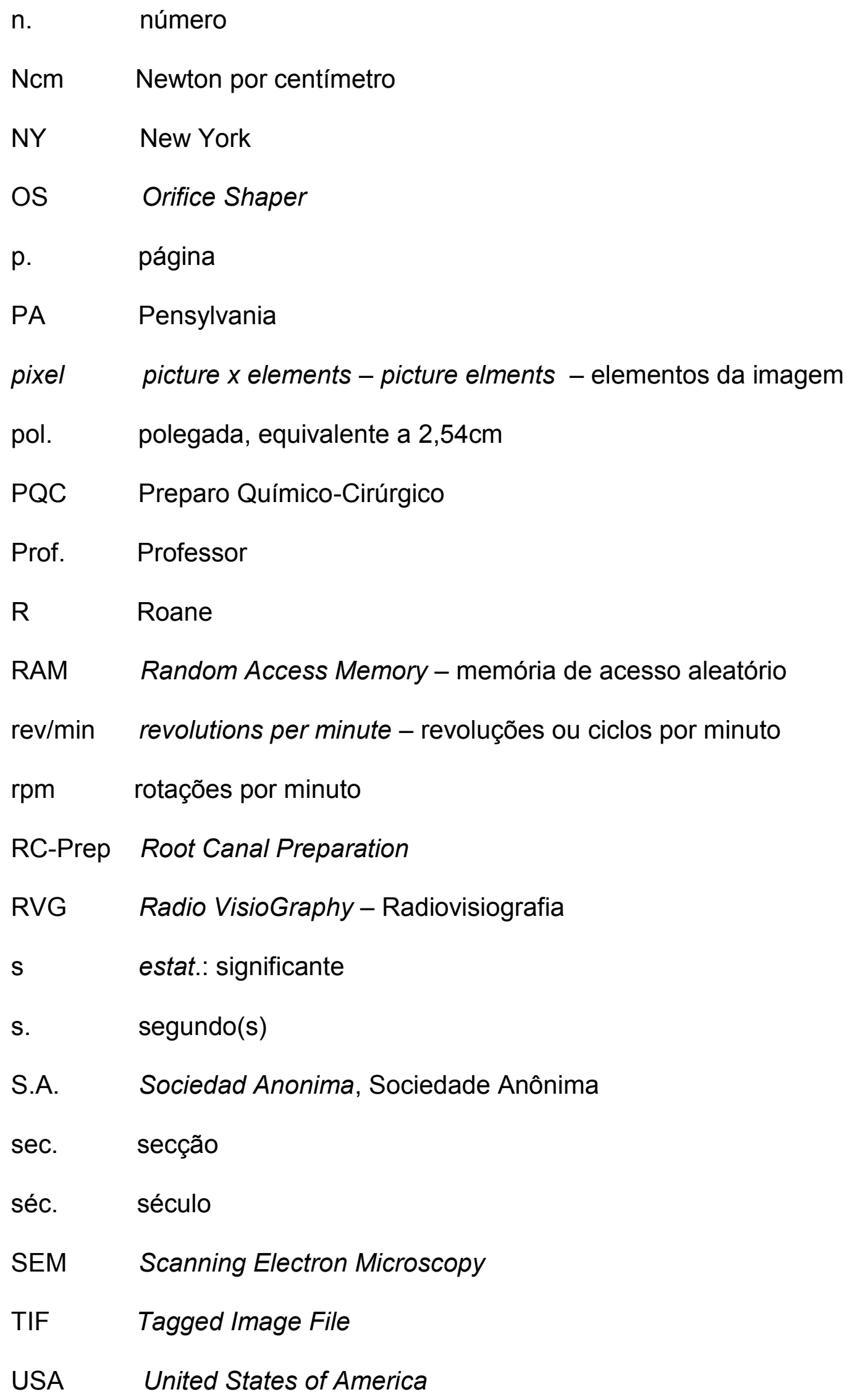




$\begin{array}{ll}\text { vs. } & \text { versus - em oposição } \\ \text { vol. } & \text { volume }\end{array}$




\section{LISTA DE SÍMBOLOS}

K lima tipo $\mathrm{K}$

H lima Hedströem

x operador matemático de multiplicação; vezes

\# número

$\%$ por cento, porcentagem, percentual

$\circ \operatorname{grau}(\mathrm{s})$

${ }^{\circledR} \quad$ marca registrada

тм trademark

$=$ igual

\& e (conjunção) comercial

a estat:: letra grega alfa, símbolo para nível de significância

$q$ estat:: amplitude estudentizada

n estat:: número de espécimes ou repetições

k estat:: número de amostras 
$\bar{x} \quad$ estat:: média aritmética

$s^{2} \quad$ estat:: variância

s $\quad$ estat:: desvio padrão

@ engl.: at (prepos. em), arroba em informática 


\section{RESUMO}

\section{MORFOMETRIA COMPARATIVA IN VITRO DO DESGASTE DENTINÁRIO DO TERÇO CERVICAL DE RAÍZES MÉSIO-VESTIBULARES DE PRIMEIROS MOLARES SUPERIORES PRODUZIDO POR INSTRUMENTOS ROTATÓRIOS DE AÇO E DE NÍQUEL-TITÂNIO}

No preparo dos canais radiculares, eminentemente os curvos, a abordagem cérvico-apical amplamente difundida promovendo a dilatação da região cervical do canal radicular previamente à atuação de instrumentos em sua região apical constitui técnica e inegavelmente uma forma adequada, tanto do ponto de vista mecânico como microbiológico, de interagir com o espaço endodôntico em busca de uma experiência bem sucedida e previsível. De outra forma, os mais recentes instrumentos endodônticos, muito mais flexíveis em decorrência das novas ligas de baixo módulo de elasticidade empregadas em sua fabricação e dotados de novos índices de conicidade, surgem melhorando tais perspectivas. Desde o surgimento da liga de Níquel-Titânio na Endodontia, na década de oitenta, uma gama imensa de instrumentos desta derivados e para serem empregados com dispositivos mecânicos, eletromecânicos ou pneumocânicos, têm reavivado a esperança de se obter 
um dispositivo ideal que simulando a cinemática manual supere as limitações operacionais decorrentes, principalmente, da configuração anatômica do canal radicular. Assim, neste experimento verificou-se o desempenho de quatro diferentes recursos técnicos no desgaste da região cervical do canal radicular. Constituíram-se quatro amostras, cada qual composta de 10 espécimes (raízes mésio-vestibulares de primeiros molares superiores), para serem preparadas com (i) Brocas Gates-Glidden, (ii) Brocas Largo-Peeso, (iii) ProFile $^{\circledR} .04 / .06$ \& Orifice Shapers e (iv) Pow- $\mathrm{R}^{\mathrm{TW}}$ Coronal Shapers. Imagens digitais obtidas antes e após o preparo do canal radicular foram analisadas também digitalmente - estudo morfométrico computadorizado - avaliando-se a variação das áreas das mesmas em função do desgaste promovido pelos referidos instrumentos. Todos os instrumentos produziram desgaste de ambas as paredes, mesial e distal, do canal radicular na região analisada. A análise estatística das variações de área para o fator parede mesial não mostrou diferenças estatisticamente significantes entre os grupos experimentais para $\alpha=5 \%$. No entanto quando da comparação dos grupos experimentais para 0 fator parede distal verificou-se diferenças estatisticamente significantes entre os grupos \#1 e \#3 para $\alpha=5 \%$. Ainda, para o fator área total (paredes mesial e distal) verificou-se diferenças estatisticamente signifcantes entre os grupos \#3 e \#4 para $\alpha=5 \%$. Concluiu-se que todos os instrumentos testados produzem desgaste tanto da parede mesial como da parede distal do canal radicular e, conseqüentemente, da estrutura dentinária global da região cervical do canal radicular. Por outro lado verificou-se uma tendência da Broca Gates-Glidden em promover maior 
desgaste da parede distal que o Sistema ProFile ${ }^{\circledR} .04 / .06$ \& Orifice Shapers e do Sistema Pow-R ${ }^{\mathrm{TM}}$ Coronal Shapers em promover maior desgaste da estrutura toal que o Sistema ProFile ${ }^{\circledR} .04 / .06$ \& Orifice Shapers. 


\section{INTRODUÇÃO}

O homem é uma corda, atada entre o animal e o além-do-homem - uma corda sobre um abismo.

Friedrich Wilhelm Nietzche (1844-1900)

Historicamente, na Endodontia uma gradativa melhor compreensão dos aspectos biológicos relacionados ao Complexo Dentino-Pulpar, tanto nos estados de normalidade como de doença, acabaram por determinar uma melhor abordagem terapêutica dos canais radiculares.

Apesar do conhecimento acumulado nas áreas da Histologia e Histopatologia, Anatomia e Anatomopatologia, Fisiologia e Fisiopatologia na Odontologia no fim do séc. XIX, esta sinalização de mudanças significativas deu-se basicamente como resultado das investigações na área da Ciência Microbiológica, assim como na Ciência Médica.

O conhecimento mais acurado dos aspectos biológicos relacionados, como os topográficos dentais internos, e o entendimento da mecânica envolvida nos processos patológicos tanto de ordem pulpar como principalmente periapical atuaram como mola propulsora na busca de um arsenal e técnicas que melhor se adequassem às necessidades efetivas do tratamento endodôntico. 
O papel do debridamento mecânico das paredes internas do canal radicular como pressuposto do trinômio limpeza-modelagem-selamento somente passou a ser melhor compreendido a partir de um melhor entendimento do papel do componente bacteriano dentro do contexto das afecções endodônticas.

Dessa forma a dilatação tridimensional do canal radicular respeitando limites espaciais de ordem anatômica e o emprego de substâncias quimioterápicas localizadas e biologicamente adequadas acabaram por resultar na construção de um espaço endodôntico inviável ao crescimento bacteriano e menos desafiador à atuação reparadora do sistema de defesa do organismo em busca da resolução do processo patológico.

Do ponto de vista logístico, e no que concerne ao instrumental manual endodôntico, os trépanos de Fauchard constituíram os primeiros instrumentos endodônticos destinados a atuar no interior do canal radicular mesmo que objetivando, primordial e exclusivamente, o seu esvaziamento.

O atual conceito de preparo dos canais radiculares aludindo para a simultaneidade dos procedimentos de descontaminação e dilatação, ou seja a limpeza e a modelagem do sistema de canais radiculares respectivamente, é relativamente recente na história da Endodontia. Interdependentes, haja vista o caráter multifatorial da abordagem endodôntica, a investigação epistemológica relacionada ao preparo dos canais radiculares, na área microbiológica assim como a referente aos aspectos de ordem mecânica relacionados, resultou no aprimoramento tanto do arsenal como da técnica endodônticos. Dessa forma, as ligas iniciais rígidas de Aço Carbono 
empregadas para a confecção dos instrumentos manuais foram substituídas pelas de Aço Inoxidável e estas mais recentemente por ligas de NíquelTitânio cujo grande atributo, a superelasticidade, é conseqüência de um módulo de elasticidade muito menor que o das ligas de Aço Inoxidável. Assim, elaboraram-se melhores técnicas para a exploração do comprimento radicular a ser trabalhado, de tal forma que se impetrasse aos instrumentos endodônticos cinemáticas melhores, mais seguras e produtivas para fins de corte das paredes de dentina com vistas ao estabelecimento de uma forma espacial adequada e de tal forma a minimizarem-se as deformações, os desvios da configuração endodôntica original, quando da atuação excêntrica do instrumento.

O princípio da abordagem cérvico-apical no preparo dos canais radiculares traduzida tecnicamente na dilatação da região cervical pela ação mecânica de instrumentos rotatórios previamente à intervenção na região do terço apical do canal radicular, viabilizando-se o início do preparo desta região com instrumentos de maior diâmetro, constituiu filosoficamente um grande avanço na Endodontia no que tange à dilatação-sanificação e subseqüente selamento hermético do sistema de canais radiculares.

No entanto, ainda do ponto de vista ergonômico, remanescia o antigo desejo de que um aparato mecânico pudesse de forma rentável e segura reproduzir ou melhorar a cinemática manualmente empregada para o preparo dos canais radiculares. Dessa forma, o processo de automatização da fase de preparo dos canais radiculares principia na década de setenta com o surgimento no mercado de aparelhos como o Racer e o Giromatic, 
passando pelos aparelhos sônicos e ultra-sônicos na década de oitenta, culminando com a série atual de dispositivos ou mecânicos (pneumomecânicos e eletromecânicos comercialmente disponíveis e criados para o emprego dos instrumentos rotatórios de Níquel-Titânio) ou para o emprego de LASER.

Destarte as especificações editadas na década de setenta estabelecendo padrões para a fabricação dos instrumentos endodônticos quanto às propriedades químicas e físicas das ligas e mecânicas e geométricas dos instrumentos, verifica-se atualmente a adição de novas variáveis na confecção dos mesmos traduzidas, principalmente, pelo emprego de novas ligas e pela nova geometria representada pelos novos índices de conicidade.

Dessa forma, as recentes ligas empregadas na confecção dos instrumentos endodônticos manuais ou rotatórios os dotam de uma apreciável maior flexibilidade que aliada à nova geometria visa por excelência uma maior interatividade do instrumento com a parede interna do canal radicular de tal forma a obter-se uma melhor sanificação e uma melhor modelagem, menor extrusão apical do conteúdo do canal, menor tempo operatório e maior conforto para o clínico e para o paciente, aspectos relevantes para o tratamento endodôntico bem sucedido. 


\section{REVISÃO DA LITERATURA}

Porque conhecer é como nunca ter visto pela primeira vez, E nunca ter visto pela primeira vez é só ter ouvido contar. Alberto Caeiro (1888-1935)

A concepção de ordem essencialmente mística da associação das doenças e epidemias à sentença punitiva da Natureza, à obsessão por espíritos maléficos bem como à variação de humor dos deuses constituintes do panteão próprio de cada cultura e como conseqüência direta da dinâmica humana repreensível sobre a face da Terra perde-se na História dos Tempos. O estado mórbido como reflexo direto do desajuste primordialmente de nível abstrato implicava em que a busca pela integridade se manifestasse de forma estoicamente litúrgica que através da leitura dos símbolos relacionados à fenomenologia atuante determinaria a conscientização e a compreensão dos desígnios do Homem em sua experiência telúrica. Dessa forma os recursos atávicos para a leitura de sinais tanto para fins de diagnóstico como para fins de cura visava efetivar a libertação do espírito e a purificação do corpo para a remissão dos sinais e sintomas da doença em um processo que supunha 
tributo e sacrifício. Em mais amplo sentido e na interação do humano com o divino o caráter sublime tanto da doença como da cura traduzia os mais recônditos sentimentos de impotência do Homem Primitivo e a cura o cumprimento e a aprovação dos anseios de fertilidade e prosperidade.

Ainda nos primórdios tempos verifica-se a partir da suposição do potencial de transmissibilidade da doença, a prescrição de isolamento do doente, a quarentena, bem como o descarte de seus pertences. Simultaneamente e sob forte inspiração religiosa advogavam-se medidas profiláticas de caráter público que estabeleciam prescrições de dieta e higiene (Evans, 1994).

Destes tempos, como mostra o Código de Hamurabi dos Babilônios no séc. XVIII A.C., tanto a prática especializada do ofício como o estabelecimento de critérios que a regulassem com a punição dos infratores ou recompensa dos bem sucedidos são características relacionadas ao exercício da arte de curar (Ring, 1985a).

O Papiro de Hearst, o de Edwin Smith e o adquirido de um árabe pelo alemão Georg Ebers em 1827, o Papiro de Ebers datado do séc. XVI A.C., são os mais antigos textos médicos com referências às afecções dentais e o Papiro de Anastácia, datado do séc. XVII A.C., mostra a associação dos processos odontológicos destrutivos ao que denominavam toothworms, larvas ou germes, parasitas e que consumiam o dente (Ring, 1985a, 1985c; Reader's Digest, 1999; De Deus, 1986).

A recente descoberta de um fóssil, o esqueleto de um guerreiro Nabateu (das tribos da Síria) datando de 200 A.C., mostra a tentativa de se 
impedir o avanço destes germes para o interior do dente através da inserção de um fio de bronze de $2,5 \mathrm{~mm}$ no interior do canal radicular de um incisivo lateral superior, o que caracteriza o mais antigo tratamento endodôntico documentado da História da Odontologia (Ingle et al., 1994).

Paralelamente à medicina sacerdotal dos filhos de Asclépio, o Deus Esculápio com seu bastão em que se enroscava uma serpente, Hipócrates (460 A.C.) referindo-se à Medicina como Ciência e Arte concebe o estado de saúde como resultado do equilíbrio entre cinco humores cardinais e quatro condições elementares e sua prescrição de abordagem do paciente através de observação racionalizada, análise de dados coletados e elaboração de um diagnóstico assim como a proposição de um plano de tratamento o torna fundador da Propedêutica ou Semiotécnica, um marco na evolução filosófica da História da Medicina (Davis et al., 1973. Gordon, 1996).

O enciclopedista romano Celsus (25 A.C.-50), o Cícero medicorum cuja enciclopédia consta dos primeiros livros impressos em 1478, prescreve uma série de medidas para o tratamento da dor de dente, dentre a pior das torturas, e a sua grande contribuição está na observação e descrição dos sinais e sintomas da inflamação, ou seja, a dor, o calor, o rubor e o tumor (Ring, 1985a, Gordon, 1996).

As concepções hipocráticas do contagium e do miasma - um como resultado da transmissibilidade e o outro matéria morta, inanimada, emanações mefíticas ou vapores venenosos criados pela influência de conjunções planetárias ou distúrbios provenientes do interior da Terra - assim como a obra repleta de equívocos de Claudius Galenus (166-210), o médico 
grego que vivia em Roma e denominado o cirurgião dos gladiadores, perduraram na aceitação dos dedicados à arte de curar, escolásticos ou barbeiros, por aproximadamente quinze séculos (Davis et al., 1973; Bier, 1990; Gordon, 1996; Evans, 1994).

Embora Arquigenes recomende a exérese pulpar para o alívio da dor e preservação do dente no primeiro século da Era Cristã, os chineses provavelmente empreguem o arsênico para a mortificação pulpar e alívio da dor no séc. II, o cirurgião indiano Vagbhata discuta o preenchimento da cavidade de cárie com cera a ser evaporada com uma sonda aquecida para a morte dos germes no séc. VII, Serapion empregue o ópio na cavidade de cárie no séc. X e o médico árabe conhecido no Ocidente por Albucasis prescreva a cauterização da lesão cariosa no séc. XI, ainda no séc. XIII a prática de fumigação consistia em fazer o paciente expor o dente acometido, usando-se um funil, à fumaça de um braseiro onde queimavam ou pequenas bolas feitas de sebo de ovelha e alho poró ou henbane seeds com o intuito de se afastar as larvas responsáveis pela enfermidade e que destruíam o dente (Ring, 1985b, 1985c; De Deus, 1986; Leonardo, 1991).

O Professor da Universidade de Salerno (Itália) e forte opositor dos preceitos galênicos, alquimista e idealizador da doutrina das assinaturas das plantas, o suíço Theophrastus Aureolus Bombastus von Hohenheim, Paracelsus, 1493-1541, preconiza a uroscopia como recurso diagnóstico e cria a farmacoterapêutica ao advogar o papel relevante da Química na preparação dos medicamentos (Gordon, 1996; Ring, 1985c). 
Sob forte inspiração do Renascimento, com sua Filosofia Humanista numa releitura do Mundo, Leonardo Da Vinci (1452-1519) produz desenhos precisos de Anatomia Humana como ilustrações de suas dissecções e Vesalius, 1514-1564, descobre a câmara pulpar no interior de um dente extraído. Eustáquio, um pupilo de Vesalius, compilou e publicou em 1563 todo o conhecimento sobre Anatomia, Histologia e Fisiologia dentais até então existentes (Ring, 1985d).

Enquanto o militar francês Ambroise Paré (1510-1590), o grande cirurgião do séc. XVI, recomendava para o tratamento de cáries o emprego de óleo de cravo e a cauterização com ácido, têm-se na Alemanha no ano de 1530 a publicação de Artzney Buchlein (Pequeno Livro Médico para todos os tipos de Doenças e Debilidades dos Dentes), o primeiro livro dedicado inteiramente à Odontologia e endereçado a barbeiros e cirurgiões e sob inspiração galênica (Ring, 1986c; De Deus, 1986; Leonardo, 1991).

Apesar da doutrina do Contagium vivum do médico epidemiologista italiano Hyeronymus Fracastorius, Girolamo Fracastoro o poeta de Verona, 1546, supor a transmissibilidade através de fomites - contágio direto ou indireto através de objetos inanimados ou à distância - contaminados com sementes invisíveis a que denominava seminaria, estes ainda são tempos de associação da semente primeira das doenças e epidemias às manifestações sobrenaturais, telúricas ou cósmicas (Davis et al., 1973; Bier, 1990; Gordon, 1996).

Esta fase de caráter genuinamente experimentalista perdura até o séc. $\mathrm{XVI}$ quando ainda a medicina formal nascida do ensino universitário relega a 
segundo plano as doenças relacionadas aos dentes e estas ficam aos cuidados de cirurgiões e barbeiros. Além da atuação militar, sob um mesmo teto barbeiros promoviam cortes de cabelo, sangrias, tratamento de ferimentos e extrações de dente. O tratamento de dentes consistia exclusivamente no alívio da dor através do emprego tópico de substâncias químicas como o ópio ou através da cauterização química, por substâncias como o arsênico, ou térmica com sonda metálica incandescente. Em última instância a abordagem profissional era de natureza proeminentemente curativa e quaisquer procedimentos terapêuticos, a mortificação pulpar ou a extração do dente, visavam essencialmente a eliminação da dor (Ring, 1985c).

No séc. XVII nasce a Fisiologia sob os auspícios das descobertas do médico e anatomista inglês William Harvey que publica em 1628 suas descobertas acerca da circulação do sangue e que levam o italiano Marcelo Malpighi a descobrir os capilares em 1666 e ser considerado o fundador da Histologia (Ring, 1985d; Gordon, 1996).

A investigação epistemológica como pressuposto do que hoje entendemos no Ocidente por Ciência e descaracterizando o longo período de base a princípio intuitiva-supersticiosa e subseqüentemente empiricista, torna-se mais evidente na área médica quando mediante suas primeiras observações microscópicas o habilidoso holandês Antony van Leeuwenhoek de Delft, que em 1678 observara a estrutura dental e descrevera os canalículos dentinários, relata em sua carta de 17 de Setembro de 1683 à Royal Society of London suas experiências com lentes de aumento 
descrevendo e ilustrando o que denominava animalcules e transformando-se no pioneiro da observação microscópica efetiva no campo da Ciência Médica (Gordon, 1996; Davis et al., 1973; Bier, 1990; Evans, 1994, Sundqvist, 1990).

Durante a Revolução Industrial e pouco antes da Revolução Francesa e do domínio napoleônico, o cirurgião francês Pierre Fauchard considerado o Pai da Odontologia Moderna e criador da expressão Chirurgien dentiste compila as informações disponíveis referentes ao tratamento dos dentes e publica Lê chirurgien dentiste, ou, traté dês Dents (O Cirurgião Dentista ou Tratado dos Dentes) em 1728, fazendo considerações sobre a morfologia dental, recomendando a remoção de polpas doentes e a inserção de uma sonda no interior do canal radicular para a drenagem de abscessos e alívio da dor e rejeitando a teoria dos germes ou larvas. Na edição de 1746 prescreve o uso de instrumentos endodônticos, os quais denomina genericamente trépanos, para o esvaziamento do canal radicular e confeccionados de cordas de piano temperadas, seccionadas em tamanhos apropriados e entalhadas para a produção de farpas, tornando-o o pioneiro na ação mecânica de artefatos metálicos no interior dos canais radiculares. Em 1775 Etienne Bourdet, dentista de Luís XV e seguidor de Fauchard, preenche os canais radiculares com folhas de ouro (Ring, 1985e; De Deus, 1986; Leonardo, 1991; Bombana, 1985).

O ilustre médico inglês $\mathrm{Dr}$. John Hunter, que se destaca por seus trabalhos sobre Anatomia Dental, relata em 1773 a gengivite e a piorréia afirmando que estas poderiam constituir fonte de infecção para qualquer outra região do organismo (Ring, 1985e). 
Em 1838 Edward Maynard produz sondas farpadas confeccionadas a partir de molas de relógio, preservando-as em aço destemperado, e dilatadores de secções transversais triangular e quadrangular a partir de cordas de piano o que incipientemente constitui o que hoje entendemos por preparo dos canais radiculares (Leonardo, 1991; Bombana, 1985; De Deus, 1986).

Segundo Mills (1883) em 1878 um método para a remoção pulpar consistia no empalamento da polpa através de uma fina haste e, de acordo com Kirk (1900), Lee (1915), Moffitt (1922) e Kells (1923), extirpa-nervos, sondas e brocas Gates-Glidden eram empregados para a remoção da polpa no fim do séc. XIX (Wildey \& Senia, 1989).

Auguste Maillefer fundou a Fabrique D'Instruments Dentaires em Ballaigues na Suiça, em 1889, produzindo extirpa-polpas(sic) em diversos tamanhos (Guerisoli et al., 1999).

Em 1886 Greene Vardiman Black supõe o Ácido Lático como produto de fungos das cáries dentais, os estreptococcus orais, e seu contemporâneo e também norte-americano o Dr. Willoughby Dayton Miller, originalmente químico e físico e posteriormente Professor de Odontologia da Universidade de Berlim, estagiando no laboratório do Dr. Robert Koch lança no meio científico em 1890 seu trabalho Microorganisms of the human mouth (Microorganismos da Cavidade Bucal) descrevendo a microbiota bucal e a Teoria Acidogênica da Cárie e inaugurando a fase da Odontologia Preventiva ao sugerir a higiene oral como uma forma de se evitar a cárie. A partir da investigação microbiológica de 250 polpas humanas através de cultura, 
inoculação em ratos e microscopia o pesquisador descreve diferentes formas bacterianas em diversos estágios de alteração tedicual relacionando-as à etiopatogena pulpar (Ring, 1985f; Leonardo, 1991; De Deus, 1986; Miller, 1894).

Em 1884 o médico vienense Karl Koller emprega a cocaína injetada em músculo, nervos, medula ou de forma tópica como anestésico local e em 1904 o químico alemão Alfred Einhorn elabora a Novocaína (Gordon, 1996).

Em 1895 o Professor de Física alemão Wilhelm Conrad Röentgen trabalhando com raios catódicos observa raios cuja origem desconhece e os chama raios $x$ e oito meses depois, em 1896, o Dr. Edmund Kells realiza clinicamente a primeira tomada radiográfica odontológica (Ring, 1985f; Leonardo, 1991; Freitas, 1988).

Em fins do séc. XIX embora o conhecimento acumulado sobre Anatomia, Fisiologia, Histologia, Patologia, Radiologia e Microbiologia - a Anatomia Dental de Da Vinci, Vesalius e Hunter; as descobertas de Leeuwenhoek; as criações de Fauchard e Maynard na forma de artefatos metálicos a serem empregados no esvaziamento e dilatação dos canais radiculares; o emprego clínico dos raios x por Kells; o emprego da cocaína como anestésico local por Koller; a Histopatologia de Virchow; as investigações de Miller, etc. - a terapia endodôntica consistia ainda basicamente no alívio da dor.

No entanto, os achados de Miller acabaram por promover uma corrida em busca de um arsenal químico de efetivo potencial antisséptico, desinfectante ou esterilizante e que redundou no emprego de substâncias 
químicas altamente irritantes, cáusticas, como os derivados fenólicos, formaldeídos, Ácido Sulfúrico e compostos de Sódio entendendo-se por tratamento endodôntico a desvitalização pulpar, o esvaziamento, alguma dilatação e o preenchimento dos canais radiculares.

Por outro lado verifica-se no século dezenove o período áureo da pesquisa em Microbiologia com o estabelecimento definitivo da relação entre microorganismos bacterianos, fúngicos e viróticos e determinados processos patológicos.

Entretanto restava ainda à Endodontia desenvolver uma visão mais ampla de horizonte e que definisse de forma integral e equacionada os vários aspectos pertinentes à abordagem terapêutica dos canais radiculares e que respeitavam, principalmente, à patogenia das endodontopatias e das periapicopatias a partir da atuação insidiosa de microorganismos assim como às relativas à forma adequada de tratamento das mesmas.

Dessa forma apesar das evidências radiográficas de Price em 1901 de tratamentos endodônticos insatisfatórios, das considerações do médico americano Frank Billings (1904 e 1921), o criador da Teoria de Infecção Focal e do bacteriologista Edward Rosenow (1922), criador da Teoria da Localização Eletiva acerca de infecções localizadas, a filosofia e a técnica endodônticas somente alteram-se relevantemente quando de uma conferência - The role of sepsis and antisepsis in Medicine ( $\mathrm{O}$ papel dos agentes sépticos e antissépticos na Medicina) - na inauguração da Faculdade de Medicina da Universidade McGill em Montreal no Canadá em 3 de Outubro de 1910, pelo médico inglês William Hunter. Ressuscitando a concepção de 
infecção focal de John Hunter (1773) condena o tratamento de canal ao afirmar que microorganismos localizados em infecções crônicas afixadas aos ápices de dentes tratados endodonticamente e assintomáticos estariam se disseminando através da corrente circulatória e alojando-se em outras regiões do organismo definindo novos sítios ou focos de infecção (Leonardo, 1991; De Deus, 1986; Hunter, 1911).

A significativa repercussão do pronunciamento de Hunter, seis anos antes da publicação da Teoria da Relatividade Generalizada de Albert Einstein (1914), traduz-se num alarde que leva a Odontologia e a Endodontia ao descrédito e à prescrição deliberada de extrações de dente pelos profissionais tanto da área médica como odontológica. Contudo, nas décadas subseqüentes uma grande gama de cientistas americanos e europeus empreendem um volume considerável de pesquisas nos campos da Anatomia, Radiologia, Bacteriologia e Histopatologia dentais em busca de um melhor entendimento dos eventos biológicos relacionados principalmente aos dentes portadores de polpa morta e suas lesões perirradiculares.

Positivamente, esse status quo acaba por gerar uma postura mais preservacionista da classe odontológica em respeito à parâmetros de ordem biológica e, dentro deste contexto surgem, as primeiras considerações com relação à importância da fase cirúrgica ou de instrumentação na desinfecção dos canais radiculares e ao uso de drogas menos irritantes aos tecidos periapicais. Assim a patente da lima tipo $\mathrm{K}$ é solicitada pela Kerr Manufacturing Company de Romulus, Michigan-USA em 1915 (Wildey \& Senia, 1989); Herman lança uma pasta à base de $\mathrm{Ca}(\mathrm{OH})_{2}$ (Hidróxido de 
Cálcio) para a obturação de canais radiculares em 1920 e Walkhoff sugere o uso de Paramonoclorfenol Canforado em 1929. Grove refere-se à necessidade de padronização do diâmetro dos instrumentos endodônticos em 1929 e limita a instrumentação ao limite CDC (Cemento-Dentina-Canal) em 1931 (Leonardo, 1991).

Neste período e quanto à topografia dental interna De Deus, 1986, em sua breve resenha histórica acerca do estudo da cavidade pulpar relata que até 1914 com Preiswerk e 1925, quando da publicação do extenso trabalho de Walter Hess (1885-1980), as pesquisas e observações sobre a topografia da cavidade pulpar eram baseadas em métodos precários e muitas vezes inadequados(sic). Segundo o autor, Hess relata que uma descrição mais detalhada com o número e direção dos canais radiculares foi realizada por Carabelli em 1844, e que entre os pesquisadores de anatomia dental estão Miller (1903), Zurcher (1925), Okumura (1927), Pucci \& Reig (1945), Aprile \& Aprile (1947), Sicher (1955), De Deus (1960), Teixeira (1963), Pineda \& Kutler (1972) e Vertucci \& William (1974).

Os achados divergentes entre as análises bacteriológicas e histopatológicas de regiões periapicais realizadas nas primeiras décadas do séc. XX quanto à presença ou ausência bacteriana in situ, levaram Fish \& McLean (1936) a concluírem que os microorganismos de hemoculturas positivas de alvéolos e ápices radiculares assim como as relacionadas à bacteremia transitória pós exodontias advinham de bolsas periodontais (Leonardo, 1991). 
Em 1934 H. A. Gins é o primeiro pesquisador a relatar a natureza anaeróbica de microorganismos isolados da cavidade bucal e de seus processos infecciosos (Evans, 1994).

Neste curso de eventos o inglês Wifred Fish, em 1939, associa como causa exclusiva dos processo patológicos periapicais a presença de microoganismos e de seus produtos tóxicos no interior de canais radiculares portadores de tecidos pulpares degradados. Em seu experimento, após inserir em cavidade artificial em mandíbula de porco fibras de algodão mergulhadas em caldo de cultura de streptococcus ou de staphylococcus, descreve suas observações microscópicas de quatro zonas concêntricas - infecção, contaminação, irritação e estimulação - e conclui que a zona de estimulação atuaria de forma a limitar a disseminação da infecção (Leonardo, 1991; Fish, 1939).

Do ponto de vista bacteriológico o trabalho de Fish leva a conclusão de que a terapêutica endodôntica deveria restringir-se ao interior do canal radicular o que associado aos conceitos biológicos emergentes termina por colocar a Endodontia em bases cientificamente mais seguras.

Sinalizando ainda a importância do teste bacteriológico como critério analítico do ambiente intracanal para a avaliação dos diferentes recursos de ordem técnica, Auerbach em 1953 após a instrumentação, irrigação com soda clorada e medicação antibiótica de 60 dentes portadores de polpa morta verifica que $78 \%$ destes resultam em culturas negativas. Stweart em 1955 ao pesquisar a importância do preparo químico-mecânico do canal radicular irriga 50 dentes despolpados e infectados com soluções de Peróxido de 
Hidrogênio a 3\% e Hipoclorito de Sódio a 5,25\% e não obtém em 94\% dos dentes crescimento bacteriano logo após a instrumentação. Este último, aliado a outros pesquisadores, retoma a pesquisa referida acrescentando-lhe uma nova solução irrigadora, o Gly-oxide, e novamente obtêm mais de $90 \%$ de culturas negativas (Klayman \& Brilliant, 1975).

Assim esta nova e mais abrangente óptica, o tratamento endodôntico bem sucedido como uma questão multifatorial, leva ao surgimento de uma técnica melhor elaborada e que prescrevia a ação mecânica de instrumentos endodônticos associada a soluções irrigadoras para o esvaziamento e alargamento do canal radicular, interferindo-se de forma mais apropriada com a morfologia dental interna e com o conteúdo séptico, assim como emprego de uma medicação intracanal menos agressiva - a melhor compreensão dos aspectos microestruturais e microbiológicos do complexo dentino-pulpar e dos tecidos periodontais, em última instância, o respeito à integridade anatômica perirradicular com vistas à reparação.

2.1 Do preparo do canal radicular

A conscientização da importância da fase de preparo dentro da terapêutica endodôntica suscitou uma busca ampla da melhor forma de 
emprego destes artefatos metálicos, já então associados à desinfecção com soluções irrigadoras, levando ao surgimento de uma série de técnicas ou artifícios de técnica aos quais normalmente atribuíam seus nomes os idealizadores. Metodologias de pesquisa diversificadas (análise microscópica, fotográfica, projeções de diapositivos, radiográfica, moldagens, analise de secções transversais, microbiológicas, análise de canais simulados em blocos de resina, análise de imagens digitais, análise tomográfica, análise xerográfica, pesquisa com corantes e radioisótopos, etc.), pesquisando a capacidade de corte e as propriedades químicas e físicas (resistência a torção e à deflexão, fadiga, etc.), qualidade dos preparos quanto à sanificação e deformação dos canais, etc., foram utilizadas para o estabelecimento da melhor relação entre o instrumento e o espaço endodôntico na busca da forma ideal a ser definida com o preparo, da forma ideal para fins de obturação, de instrumentos e manobras que promovessem a remoção efetiva de restos necróticos e dentina contaminada, tendo em conta os aspectos topográficos internos do canal, sem levá-los para os espaços periapicais, assim como o estabelecimento de parâmetros para minimizar erros e reduzir o tempo de trabalho.

\subsubsection{Do preparo manual}

Destarte as referências de Grove em 1929 acerca da necessidade de padronização dos diâmetros dos instrumentos empregados no preparo dos 
canais radiculares somente quase três décadas depois a questão é reconsiderada.

A princípio em 1958, segundo Schneider (1971), durante as transações da Segunda Conferência de Endodontia na Universidade da Pensylvania, em Philadelphia (USA), Ingle \& Levine ao discorrem sobre a necessidade de uniformidade dos instrumentos e equipamentos endodônticos, bem como dos materiais obturadores, aludem para que o objetivo primordial da operatória endodôntica deve ser o desenvolvimento de um selamento hermético ao nível do forame apical e a obliteração total do espaço do canal radicular(sic). Deste evento resultam as primeiras especificações para a padronização dos instrumentos endodônticos, limas e alargadores, e materiais obturadores, gutta-percha e cones de prata.

Posteriormente em 1961, Ingle publica um artigo em que considera o índice de insucesso dos tratamentos de canais radiculares em 5,55\% estabelecendo como suas principais causas o erro na seleção de casos e os erros de ordem técnica. Relata que em uma pesquisa realizada pela Universidade de Washington, os tratamentos endodônticos mal sucedidos estavam relacionados à obturações deficientes e iatrogenia na forma de perfurações radiculares. Considera a obturação tridimensional dependente da cuidadosa preparação coronária e radicular, da adequada seleção de caso, bem como do material obturador adequado. Dessa forma o tratamento de canal radicular bem sucedido estaria diretamente relacionado à instrumentação adequada e uma vez que o armamentarium (arsenal) até então disponível muito desejasse com respeito à uniformidade, sugere a 
padronização do instrumental endodôntico destinado ao preparo mecânico dos canais radiculares. Sugere a compatibilização de tamanho entre instrumentos de preparo e cones de papel e obturação (prata e gutta-percha) e entre instrumentos de diferentes procedências. Define diâmetros e comprimentos assim como índices de conicidade. Advoga que tais medidas de uniformização das características físicas dos instrumentos manuais destinados à fase de preparo mecânico dos canais radiculares traria benefícios tanto ao paciente como ao operador.

Contudo, em meio à soberana arbitrariedade, Engstrom (1964) relata um índice de sucesso de tratamentos endodônticos de $85 \%$ em um estudo de quatro anos, ao estabelecer uma correlação entre culturas positivas e o prognóstico do tratamento do canal radicular (Clem, 1969).

Segundo Berger, 2000, o alargamento da região apical do canal curvo até o instrumento memória com calibre compatível com o grau de curvatura seguido do emprego de instrumentos de maior diâmetro a partir da curvatura em direção à região cervical e intercalados pelo instrumento memória, foi originalmente descrito por Gonçalves (1956) - forma conveniente ogival nos $2,0 \mathrm{~mm}$ finais e recuo escalonado - e suas vantagens descritas por Mullaney \& Petrich em 1968.

Em 1969 Clem ao publicar um artigo sobre o tratamento endodôntico de pacientes adolescentes faz considerações gerais acerca da fase de instrumentação dos canais radiculares. Cria protocolos para o tratamento endodôntico de dentes permanentes jovens com e sem rizogênese completa. Estabelece como principais objetivos da terapêutica a elaboração de 
adequados diagnóstico e prognóstico, o alívio da sintomatologia, a confecção de um acesso adequado aos canais radiculares, o preparo dos canais e a remoção do conteúdo pulpar através da instrumentação e a obturação seguida de controle bacteriológico. O autor considerou a técnica convencional de instrumentação dos canais radiculares útil em canais tubulares retos tanto de adolescentes como adultos ou em canais curvos estreitados pela formação de dentina secundária em adultos. Para o autor uma vez que em adolescentes os canais curvos apresentam pequena quantidade de dentina secundária sua instrumentação constitui problema vista sua conformação curva e estreita na região apical e afunilada na região cervical. Dessa forma o autor indica para estes casos o emprego de uma técnica dual ou Step Preparation (Técnica de Preparo Escalonado Ápico-Cervical) descrevendo-a, a título de exemplo, no preparo de um incisivo lateral superior. Segundo o pesquisador o preparo escalonado promoveria um canal clinicamente limpo de restos necróticos em toda sua extensão.

Ainda em 1969, Vessey da Escola Naval de Bethesda (Maryland, USA) compara os efeitos da limagem e do alargamento na determinação da forma dos canais radiculares. Segundo o autor, Seidler (1962) sugerira como ideal o preparo afunilado, liso, de secção transversal circular e que permitisse uma adaptação justa do cone principal objetivando-se a obliteração do canal. Considera também que autores como Ingle (1965) e Grossman (1969) descrevem diferentemente a cinemática relacionada ao emprego de limas. Em seu experimento o autor emprega 33 incisivos centrais e laterais inferiores extraídos aleatoriamente selecionados. Os dentes foram preparados de 
várias formas, seccionados transversalmente e algumas secções fotografadas. A partir da projeção das fotografias registrou-se as distâncias vestíbulo-lingual e mésio-distal dos canais a $2 \mathrm{~mm}, 3 \mathrm{~mm}, 4 \mathrm{~mm}$ e $5 \mathrm{~mm}$ do ápice. No primeiro grupo experimental, 13 dentes, o preparo foi realizado com alargadores em movimentos de alargamento. No segundo, 14 dentes, com limas em movimentos de limagem e no terceiro, 6 dentes, limas em movimentos de alargamento. Os resultados mostraram que nem alargadores nem limas, quando usados em movimentos de alargamento, produziram qualquer desvio significativo da forma circular de preparo do canal radicular enquanto que as limas, quando empregadas em movimentos de limagem, o produziram significativamente.

Considerando a afirmação de Haga (1968) de que o percentual de preparos inadequados era surpreendentemente alto em todas as categorias de canais exceto nos incisivos centrais superiores, Schneider em 1971 realiza um experimento objetivando a determinação da freqüência com que preparos de forma circular poderiam ser produzidos no terço apical de canais radiculares retos e curvos através de instrumentação manual. Para tanto o pesquisador constituiu uma amostra de 27 caninos inferiores e superiores, 1 incisivo lateral superior e 1 premolar inferior - dentes extraídos permanentes, unirradiculares e com rizogênese completa. Após a secção das coroas, os comprimentos radiculares foram padronizados em $15 \mathrm{~mm}$ a partir do ápice. Em seguida todos os espécimes foram radiografados e a mensuração do grau de curvatura de cada uma das raízes foi realizada segundo metodologia desenvolvida pelo próprio pesquisador. Então as raízes foram classificadas 
da seguinte forma: (i) retas: 5 graus ou menos; (ii) moderada: de 10 a 20 graus e (iii) severa: de 25 a 70 graus. Os canais foram preparados com limas em movimentos de alargamento exclusivamente e segundo as orientações técnicas de Haga (1968). Após obturadas as raízes foram seccionadas transversalmente, avaliadas sob microscopia de dissecção (x25), e algumas amostras representativas foram fotografadas. Os resultados demonstraram que os canais retos são muito mais prontamente preparados em forma circular que os canais curvos. Os preparos circulares foram obtidos em $51 \%$ das vezes ao nível de $1 \mathrm{~mm}$ do ápice comparados com $17 \%$ a $5 \mathrm{~mm}$. O autor concluiu serem necessários estudos adicionais para que se determine quando o canal estaria corretamente preparado.

Aludindo para que o princípio de que o canal radicular necessita ser dilatado para receber algum material que o preencha já era reconhecido de longa data mas que, no entanto, o conceito acerca do papel e da proposta do preparo do canal radicular divergia muito entre clínicos e professores, Schilder em 1974 propõe uma racionalização do tratamento endodôntico com ênfase à fase de preparo do canal radicular. Com vistas a uma análise e sistematização de ordem conceptual considerando para tanto a nomenclatura técnica vigente respeitante à fase de preparo, o autor julga que esta não reflete de forma adequada os objetivos reais desta fase, i.e. o sistema de canais radiculares deve ser limpo e modelado - limpo de seus remanescentes orgânicos e modelado para receber uma obturação tridimensional e hermética de todo o espaço do canal radicular. Assim, a modelagem implica na confecção de uma forma única para cada raiz e relaciona-se tanto ao comprimento como à 
curvatura e à posição da raiz no arco. Ao discorrer sobre os fatores mecânicos relacionados ao processo de limpeza e modelagem do sistema de canais radiculares o autor prescreve a adoção dos seguintes fatores como critérios: (i) o preparo depende do tipo de material obturador a ser empregado; (ii) a forma final deve ser afunilada; (iii) as secções transversais devem ter diâmetros gradativamente menores da região cervical em direção a região apical da raiz; (iv) manutenção da forma original do canal; (v) manutenção da posição original do forame apical e (vi) manutenção do diâmetro original do forame apical.

Além das prescrições de ordem mecânica Schilder também discorre sobre os objetivos biológicos da limpeza e modelagem do sistema de canais radiculares: (i) o confinamento do preparo aos limites do canal radicular; (ii) atenção quanto ao extravazamento do conteúdo do canal para além do forame apical; (iii) remoção de todo conteúdo necrótico, bem como raspas de dentina, do interior do canal radicular; (iv) conclusão da limpeza e modelagem do ou dos canais em uma única sessão e (v) o canal deve ser alargado suficientemente para permitir a introdução de medicação intracanal bem como acomodação de possível exsudato.

Para o autor acima referido os seguintes princípios clínicos dizem relação de forma geral ao preparo dos canais radiculares: (i) irrigação copiosa; (ii) nunca deixar de usar um instrumento de uma série antes que ele toque a região apical; (iii) o abandono de um instrumento para o subsequente de maior diâmetro somente deve ser realizado quando o primeiro houver trabalhado adequadamente a região apical; (iv) considerar a possibilidade de 
uso de um instrumento de tamanho intermediário entre dois diâmetros dados; (v) deve-se empregar limas para o preparo de canais estreitos e curvos; (vi) instrumentos com defeitos em suas lâminas devem ser descartados; (vii) os canais bloqueados através da compactação de raspas de dentina decorrentes do corte promovido pelos instrumentos devem ser pacientemente manipulados; (viii) os canais parcialmente calcificados podem ser negociados com sucesso se forem tratados desde o início como portadores de dentina compactada.

Segundo Schilder o cleaning and shaping (limpeza e modelagem), independentemente do tipo de material obturador a ser utilizado, é alcançado através da limagem e alargamento de forma seriada com constante recapitulação, a Técnica Seriada, muito mais que com a ação seqüencial de instrumentos ao nível do término apical durante todo a fase de preparo. Esta última abordagem, em função da dureza dos instrumentos de maior calibre, levaria à promoção de desvios da forma original do canal ou faria com que o operador limitasse o preparo a instrumentos de pequeno diâmetro. Por outro lado não recomenda a utilização de brocas Gates-Glidden para a limpeza e modelagem do canal radicular uma vez que estas poderiam emperrar ou fraturarem-se durante a mesma.

Dentro deste contexto de técnicas endodônticas, até o cleaning and shaping de Schilder em 1974, Vansan (1993) relata que dentre as várias técnicas de preparo do canal radicular Badan teria proposto a Manipulação Racional do Endoductodoncio (Técnica Convencional) em 1949, Clem a Step 
Preparation em 1969, Weine et al. a Incremental Instrumentation em 1970 e Weine a Flare Preparation e a Step Preparation em 1972.

Segundo Fava (1984), também em 1974 Martin apresenta sua Telescope Technic (Técnica Telescópica) para o preparo de canais radiculares: após a determinação do CRT procede-se à instrumentação dos $5 \mathrm{~mm}$ apicais até um instrumento \#25, do terço médio com limas \#35 e \#40, do terço cervical com limas de \#35 a \#50, finalizando-se o técnica com a ação regularizadora do preparo com um alargador \#25. Entre as vantagens reclamadas pelo autor estão a facilitação da obturação do canal independentemente do material a ser empregado, eliminação ou redução do grau de curvatura tornando a irrigação mais eficiente, preparo de uma matriz apical, etc.

Nesta fase a pesquisa concentra-se na busca da compreensão da dinâmica do instrumento endodôntico junto às paredes internas do canal radicular e sua relação com a remoção tecidual e a forma final ideal, entendendo-se esta última como afunilada e de secção transversal circular.

Então em 1975, Weine et al. verificam o efeito dos procedimentos de preparo sobre as formas originais do canal e do forame apical a partir do preparo de 80 canais simulados curvos padronizados confeccionados em blocos de resina de polyester transparente. Os canais foram preparados por 10 diferentes operadores usando diferentes técnicas de preparo: alargamento, limagem com $1 / 4$ de volta, limagem ou uma combinação destas, empregando-se soda clorada como solução irrigadora. Os canais foram fotografados antes, durante e após a conclusão do preparo. A análise dos 
resultados demonstrou que a despeito do operador, do tipo de instrumento ou técnica de dilatação empregados todos os canais apresentavam características finais de forma indesejáveis: nas proximidades do ápice radicular, remoção aumentada de material da parede externa da curvatura e, consequentemente, formas em ampulheta preferencialmente à formas afuniladas - nenhum preparo era afunilado a partir do orifício de entrada do canal em direção ao ápice o que dava à forma de preparo o aspecto de uma ampulheta. Chamaram à área mais estreita desta forma de elbow (cotovelo). A tendência do instrumento em retificar-se produziu preparos terminando em zip (dilaceração). Nos canais intencionalmente sobre-instrumentados verificou-se através das fotografias dos ápices uma configuração que julgaram ser mais acurado chamar de teardrop (gota), uma ocorrência à qual Schilder fizera referência em 1974 descrevendo-a como forma elíptica. Para evitar a ocorrência destes desvios, i.e. a sobre instrumentação da parede externa do canal radicular na extensão compreendida entre o início da curvatura e o ápice, os autores sugerem um artifício de técnica que consiste na remoção, com lixa de superfície diamantada para unha ou pedra montada em peça de mão, das últimas espiras localizadas na face externa do instrumento pré curvado. Além de recomendarem o preparo escalonado sugerem também o emprego do movimento de limagem em detrimento do uso do movimento de rotação.

Moodnik et al., 1976, usando MEV como método de análise, realizaram um trabalho objetivando estabelecer a eficácia da instrumentação biomecânica. Referindo os trabalhos de Ingle (1961) e Seltzer (1965) 
consideram que o tratamento endodôntico bem sucedido infere obediência a três princípios cardinais - debridamento mecânico, redução da flora bacteriana e obturação do sistema de canais radiculares - e que embora não se possa estabelecer uma escala de prioridade em relação aos mesmos é consenso entre muitos endodontistas que o debridamento mecânico do sistema de canais radiculares é o aspecto chave do tratamento(sic). Para o experimento os pesquisadores empregaram 35 dentes humanos recém extraídos dos quais 10 constituíram o grupo controle que não recebeu preparo biomecânico. Entre os outros 25 espécimes, unirradiculares, 12 foram preparados com limas tipo $\mathrm{K}$ e 13 com limas Hedströem e do total de espécimes experimentais, 20 foram irrigados com solução salina e 5 com solução de Hipoclorito de Sódio 2,5\%. Em seguida os espécimes foram divididos horizontalmente em 3 partes e cada uma destas longitudinalmente em outras 2. Os espécimes foram fixados, desidratados e revestidos por uma camada de Carbono e Ouro-Paládio. Os pesquisadores observaram (i) que os canais radiculares contêm irregularidades que alojam tanto debris como tecido pulpar necrótico, (ii) que um lado do canal não é necessariamente melhor instrumentado que o oponente, (iii) que nenhuma região do canal é melhor limpa que outra em função do preparo, (iv) que não houve diferenças na eficiência da instrumentação biomecânica nas condições experimentais testadas e (v) que todas as faces instrumentadas estavam recobertas por magma dentinário.

Abordando um outro aspecto da questão do preparo dos canais radiculares e divergindo ligeiramente da abordagem de pesquisa corrente, 
Caldwell em 1976 considerando que apesar do consenso de que do preparo de canais curvos decorre uma diminuição do comprimento de trabalho devido ao estreitamento da luz do canal como conseqüência do desgaste de sua parede interna, não se verificam experimentos que quantifiquem tal alteração. Então realiza um experimento com 80 molares, 40 inferiores e 40 superiores, humanos extraídos para a determinação da quantidade de alteração do comprimento de trabalho durante o alargamento de canais de molares e teste do grau de significância da mesma. Os canais foram medidos antes e após a instrumentação e os mais curvos apresentaram as maiores reduções no comprimento de trabalho. As maiores alterações do comprimento de trabalho foram observadas nas raízes mesiovestibulares de molares superiores com uma média de redução de $0,35 \mathrm{~mm}$ mas, no entanto, nenhuma das alterações observadas mostrou-se estatisticamente significante.

Em 1976 Walton afirma que a maior parte dos vários métodos até então propostos para o alargamento dos canais durante o tratamento endodôntico tem pouca base científica. Considerando que as pesquisas sobre o preparo dos canais radiculares tinham inicialmente por objetivo comparar as formas obtidas mediante o emprego de diferentes técnicas de preparo e que num segundo momento primavam pela avaliação de sua efetividade no debridamento dos canais radiculares, analisado com diversas metodologias, propõe a avaliação histológica destes após o emprego de diferentes técnicas de preparo. O experimento in vivo compreendeu o preparo in situ uma vez que os espécimes, 52 dentes portadores de polpas vivas perfazendo 91 canais, tinham extração indicada por razões protéticas ou periodontais. Após o 
preparo - limagem, alargamento ou escalonamento - os dentes foram extraídos, processados e os cortes histológicos foram analisados. Comparativamente, observou-se (i) que o preparo escalonado foi significativamente mais eficiente na remoção de debris e dentina das paredes do canal; (ii) que os canais retos tinham paredes mais planas que os canais curvos e (iii) que raspas de dentina claras não constituíam indício de que dentina havia sido removida de todas as paredes do canal.

Apesar de alusões bastante pregressas acerca da falta de padronização dos instrumentos endodônticos, somente em Outubro de 1976 o Conselho de Materiais e Equipamentos Odontológicos da Associação Americana de Odontologia, fundado em 1966, manifesta-se editando a Especificação \#28 para Limas e Alargadores Endodônticos. Dessa forma alistam 9 diferentes tipos de instrumentos (limas tipo K, alargadores tipo K, extirpa nervos, sonda, etc.) e 2 classes segundo a composição química (A para Aço Carbono e B para Aço Inoxidável). Dispõem requisitos de ordem dimensional, dureza e de resistências à fratura sob torção e à corrosão assim como normalizam procedimentos para fins de teste, amostragem e inspeção dos instrumentos endodônticos.

Neste mesmo mês a ADA publica a Especificação \#29 fazendo especificações gerais para os instrumentos manuais e classificando-os segundo o tipo de liga dos quais estes foram confeccionados, ou seja, Aço Carbono (Classe 1), Aço de Alto Índice de Carbono (Classe II), Aço Inoxidável Austenítico (Classe III), etc. Dessa forma estabelecem-se requisitos quanto a composição química das mesmas. 
As deliberações das especificações acima referidas normatizaram as propriedades tanto físicas como químicas a serem atendidas na fabricação de instrumentos endodônticos manuais.

Segundo Mullaney, 1979, a MEV então amplamente empregada como recurso de pesquisa, permitia constatar sobre cones de prata de obturações endodônticas produtos resultantes da decomposição do elemento químico dos quais eram constituídos. Assim abandonava-se este tipo de obturação adotando-se prevalentemente a gutta-percha sem, no entanto, encontrarem-se técnicas de preparo apropriadas disponíveis para tal finalidade. Para o autor os princípios básicos subjacentes na Stepback Technique (a Técnica de Preparo Escalonado Ápico-Cervical e a recapitulação) devem ser atribuídos à Schilder idealizador da técnica de obturação com gutta-percha aquecida. O autor estabelece comparações teóricas entre o Preparo Escalonado e duas técnicas tradicionais de preparo do canal até um instrumento \#40 e entre o Preparo Escalonado e técnicas de dilatação ampla do segmento apical do canal i.e. as técnicas do Estado de Ohio e da Universidade do Sul da Califórnia. Segundo o autor os trabalhos de Mullins (1976) e Miller (1975) foram unânimes em afirmar a superioridade do Preparo Escalonado em relação às outras duas técnicas quanto à manutenção da forma original do canal. Ao discorrer sobre os vários aspectos relacionados à instrumentação dos canais curvos e estreitos o autor afirma que a conclusão mais viável não é a de que uma técnica de instrumentação ou um material obturador é melhor que o outro(s) mas que em ambos os casos têm-se tanto pontos fortes e fracos que deveriam ser considerados quando da 
realização do tratamento endodôntico. O autor afirma que o preparo escalonado é provavelmente o melhor método de preparo dos canais radiculares desde que os procedimentos de instrumentação e limpeza sejam cuidadosamente seguidos.

Analisando um outro aspecto relacionado ao preparo dos canais radiculares Curti Jr. et al. (1980) realizaram um estudo morfológico de instrumentos endodônticos após o desgaste de dentina humana durante um período de $3 \mathrm{~min}$. Relataram que a MEV mostrou nítida e detalhadamente desgaste acentuado do instrumento com alterações de sua forma e ângulo da parte ativa, assim como fraturas mais ou menos severas(sic).

Usando MEV e comparando diferentes técnicas de preparo do canal radicular associadas a diferentes regimes de irrigação Bolanos et al., 1980, empreenderam um experimento in vitro em que empregaram 54 raízes de primeiros e segundos molares superiores recém extraídos. Os espécimes foram distribuídos em dois grandes grupos dependentemente do tipo de técnica de preparo empregada, i.e., preparo tradicional não seriado ou preparo seriado (step-back)(sic). Todos os espécimes foram instrumentados usando-se como agente quelante RC-Prep (Peróxido de Uréia 10\%, EDTA 15\% e Carbowax 75\%) associado ou a solução salina (solução de Cloreto de Sódio $0,9 \%$ ) ou a solução de Hipoclorito de Sódio $1 \%$. Dessa forma 48 espécimes foram distribuídos em 8 subgrupos experimentais, 6 espécimes cada, e 1 grupo controle. O experimento permitiu as seguintes conclusões: (i) o preparo seriado mostrou-se a melhor técnica de preparo promovendo canais mais limpos, (ii) ambas as técnicas promoveram a formação de magma 
dentinário, (iii) não houve diferenças estatisticamente significantes em função dos diferentes regimes de irrigação dos canais radiculares.

Avaliando in vitro um outro aspecto relacionado ao preparo dos canais radiculares Machado \& Pesce em 1981 realizam um estudo da região apical de dentes tratados endodonticamente até o vértice radiográfico da raiz aludindo par a importância do respeito à integridade dos tecidos vivos da região apical com vistas a um tratamento endodôntico bem sucedido. Segundo os autores os resultados do experimento permitiram inferir que a obturação do canal até o vértice radiográfico implica, na maior parte das vezes, em obturação além do forame apical.

Felt et al. averiguaram em 1982 a relação entre as características dos sulcos de quatro diferentes marcas comerciais de limas e alargadores, em três diferentes tamanhos, em relação à capacidade de corte dos mesmos. Concluíram que o grupo de alargadores testados foi significativamente mais eficiente que o grupo de limas testadas. Entre as limas e entre os alargadores testados a capacidades de corte verificadas foram as mesmas. De uma forma geral, entre os instrumentos que apresentavam as mesmas características de sulco, os instrumentos de menor calibre apresentaram melhor capacidade de corte. Os autores concluem que o efeito do desenho do sulco sobre a eficiência de corte pode, em alguns casos, obscurecer o efeito da configuração da secção transversal.

Newman et al, 1983, realizaram um experimento in vitro para a comparação da capacidade de corte de sete diferentes marcas comerciais Kerr (Sybron), Union Broach (Ubeco), Star (Syntex), Ranson and Randolph 
(Dentisply), Whaledent (Ipco) e Unitek - de limas endodônticas - tipo K, K-Flex, Flex-File, Unifile, Endex, Unitek - usadas em movimentos lineares. A capacidade de corte foi determinada através da mensuração da profundidade de corte em um espécime de osso bovino após períodos de 3min. Verificou-se diferenças estatisticamente significantes entre os sete diferentes produtos comparados assim como desgaste generalizado e diminuição da profundidade de corte a cada períodos sucessivos de $3 \mathrm{~min}$.

Taylor em 1984 discorre sobre a relação entre os avanços técnicos para preparo e obturação dos canais radiculares e a terapia endodôntica de rotina. Dessa forma, discorre sobre a tríade endodôntica, i.e. a cirurgia de acesso, o preparo do canal e a sua obturação, e os princípios biológicos e mecânicos envolvidos. Segundo o autor independentemente do método de emprego da gutta-percha, que necessita ser condensada quase que em toda a extensão do canal, importa que a forma do canal estabelecida com preparo permita a compactação deste material. Considera que num primeiro momento deva dar-se ênfase ao preparo da região apical do canal através do preparo não seriado. Em uma segunda fase, após a definição do instrumento de maior calibre possível de ser usado de forma segura na região apical, procede-se a preparo escalonado. Alternativamente sugere duas outras técnicas paro o preparo de canais difíceis de serem negociados v.g. canais atresiados, calcificados ou curvos. Nestes casos sugere ou a Instrumentação Reversa (Reverse Filing), como um escalonamento iniciado precocemente (antes de um instrumento \#25), ou o Escalonamento Reverso (Reverse Flaring), um alargamento da região cervical do canal antes que o preparo seriado ou 
preparo escalonado tenham sido concluídos. Para o autor esta técnica é mais útil nos casos de canais severamente curvos ou em forma de baioneta.

Sobre-instrumentando em 2mm 134 canais de cães, Valdrighi \& Benatti (1984) ampliaram os diâmetros dos forames apicais até as limas \#40, \#60 e \#80. Em seguida os canais foram obturados de $1 \mathrm{~mm}$ a $3 \mathrm{~mm}$ aquém do forame apical e os cães sacrificados após 3, 7, 30 e 120 dias. Segundo os autores, o experimento pode permitir as seguintes conclusões: (i) o coto pulpar(sic) pode recompor-se, em determinadas condições, e formar um coto pulpar(sic) artificial através da invaginação do tecido conjuntivo do ligamento periodontal; (ii) mesmo quando da sub-obturação(sic) $(3 \mathrm{~mm})$ tem-se a invaginação de tecido conjuntivo durante o processo de reparo; (iii) não ocorreram diferenças significativas de reparo, com exceção da verificação de crescimento ósseo para o interior do canal nos casos em que o forame apical foi ampliado com lima \#80; (iv) excluída a inflamação tecidual na primeira semana após o tratamento, com o decorrer do tempo o tecido conjuntivo apresentou celularidade reduzida, maior número de fibras e paredes vasculares mais diferenciadas e $(v)$ constatou-se cemento revestindo as paredes internas do canal.

Anderson et al. (1985) compararam a capacidade de corte, em movimentos de tração, de limas de secção quadrangular e de secção romboidal (losangular) avaliando a profundidade de corte dos mesmos em relação à tabletes de Polimetilmetacrilato. Verificaram uma maior capacidade de corte, estatisticamente significante, das limas de secção transversal losangular nos tamanhos \#30, \#35 e \#40 em relação aos \#20 e \#25. 
Lim \& Webber (1985) avaliaram a validade do emprego de canais simulados para a investigação da forma determinada pelo preparo do canal radicular. Empregaram dentes humanos extraídos e blocos de resina cujos canais foram instrumentados com limas tipo $\mathrm{K}$. até o \#25, ou seja, empregou-se apenas a fase de preparo apical do preparo escalonado. Os resultados mostraram uma alta incidência da forma em ampulheta quando os canais eram severamente curvos. Quando da comparação da proporção das deformidades não encontrou-se diferenças estatisticamente significantes.

Pesce et al., 1986, avaliaram a variação da odontometria no preparo de canais curvos de raízes mésio-vestibulares de molares superiores instrumentados pela Técnica Convencional segundo Paiva \& Antoniazzi (1984), mantendo inalterado cada comprimento de trabalho durante toda a fase de preparo. Todos os preparos foram concluídos com um instrumento \#40. Observaram diminuição do CRT (Comprimento Real de Trabalho) em função da diminuição progressiva do grau de curvatura das raízes bem como o fato de que o emprego de instrumentos de maior calibre na região apical de canais curvos determinará maior incidência de deformações no preparo desta região.

Gullickson \& Montgomery, 1987, avaliaram a precisão de uma técnica digital de processamento de imagem para o estudo da morfologia do canal radicular empregando 16 premolares inferiores unirradiculares dentre os quais um espécime foi usado para verificar se uma técnica de preparo havia sido realmente efetiva na remoção de tecido pulpar do interior do sistema de canais radiculares. Segundo os pesquisadores vários metodologias de 
pesquisa têm sido empregadas para o estudo da morfologia do canal radicular: (i) modelos transparentes tridimensionais de dentes têm sido produzidos pela injeção de corantes (Vertucci et al., 1974; Vertucci, 1978 e Vertucci \& Gegauff, 1979) ou resina colorida (Barker et al., 1969; Fisher et al., 1975) nos espaços pulpares; (ii) a infiltração de tinta da Índia no interior dos espaços pulpares seguida da diafanização do dente também permite a obtenção de modelo tridimensional (Tagger, 1976); (iii) dentes seccionados para a visualização direta dos canais (Green, 1955); (iv) estudo bidimensional de radiografias de canais preenchidos com material radiopaco (Barker et al., 1969; Rosensteil, 1957); (v) cortes histológicos de ápices e análise microscópica (Kutler, 1955) e mais recentemente (vi) computação gráfica para fins de ensino (Pao et al., 1984). Muitas destas técnicas, entre outras (Guttiérrez \& Garcia, 1968; Jungman et al., 1975 e Kessler et al., 1983), foram empregadas para demonstrar os efeitos de várias técnicas de instrumentação sobre a morfologia original do canal radicular que também foi investigada com blocos de resina acrílica transparente (Weine et al., 1975 e Weine et al., 1976). Aludem para Mayo et al. (1986), introdutores do método computadorizado para a avaliação da morfologia do canal radicular, uma vez que nenhuma das técnicas anteriormente descritas permite a análise das formas do canal radicular antes e após o preparo. O experimento permitiu que os pesquisadores observassem que: (i) o preenchimento do canal com contraste vibrando-se o dente parece ser uma boa técnica; (ii) não houve diferenças estatísticas entre os dados volumétricos e radiográficos mas, no entanto, houve entre os volumétricos e os xerográficos e (iii) as medidas de 
diâmetro estavam dentro do 0,1mm das medidas do computador em $97 \%$ das vezes com as radiografias e em $95 \%$ das vezes com as xeroradiografias. Os autores concluem que a técnica digital de processamento de imagem pode ser um método efetivo para a avaliação dos procedimentos de instrumentação e que em um mesmo dente, a morfologia do canal radicular poderia ser monitorada do princípio ao fim do preparo.

Em 1985 Roane et al. criam o conceito de Balanced Force (Força-Balanceada) para a instrumentação de canais radiculares curvos. Os autores consideraram que em função da dificuldade de preparo destes canais não se dá a sua dilatação por definitivamente realizada até que se alcance uma forma ideal tanto do ponto de vista biológico como mecânico. Segundo os autores o conceito de força balanceada teria surgido ao longo dos 12 anos antecedentes por experimentações de tentativa e erro e levou à criação de um novo desenho de lima tipo K. Para os pesquisadores a curvatura torna tão complexa a questão do preparo dos canais curvos que todos os conceitos de instrumentação já teriam sido desenvolvidos até então através dos trabalhos de Weine et al. em 1975, Mullaney em 1979, Abou-Rass et al. em 1980, Goerig et al. e Schilder \& Fulton em m 1984. Segundo os autores e do ponto de vista clínico, consideradas a lei física de ação e reação e as propriedades físicas dos instrumento de secção transversal triangular, decorrentes de aspectos de ordem geométrica, na medida em que estes instrumentos imprimem menor força sobre as paredes rígidas do canal em função de sua maior flexibilidade, têm-se uma força restauradora ou de retorno de menor magnitude assim como menores possibilidades de transporte do canal. Dessa 
forma é desejável o conhecimento das características geométricas do instrumento para que a força de restauração do instrumento frente às influências do canal possa ser prevista em função do momento de deflexão angular do instrumento. Das considerações acerca da geometria do instrumento também surge a modificação da ponta do instrumento, expressão primária da força de restauração estática, a mais dramática interferência em relação à dinâmica potencial no interior do canal radicular. Do ponto de vista técnico, o preparo segundo os conceitos de força balanceada consiste basicamente na inserção, corte e remoção de cada lima usando-se movimentos de rotação. A inserção e o corte são realizados com pressão e movimento de rotação no sentido horário.

Bramante et al. ao considerarem as várias metodologias de pesquisa disponíveis para o estudo do efeito do preparo sobre a morfologia dos canais radiculares publicaram em 1987 um artigo para a apresentação de um método objetivo para o estudo da topografia dental interna dos canais radiculares, antes e após a instrumentação, de tal forma a habilitar estudos qualitativos e estatísticos através de comparações acuradas. O método consistia na inclusão da raiz em resina autopolimerizável transparente e subseqüente inclusão dos blocos obtidos em gesso. Então os blocos são seccionados aos níveis cervical, médio e apical, fotografados, remontados para instrumentação e novamente fotografados. Após a projeção das imagens, obtidas antes e após o preparo dos canais radciulares, demarcação dos contornos e sobreposição dos perfis procede-se à mensuração das áreas com um Planimetro. 
Ao considerarem as orientações disponíveis na literatura científica endodôntica acerca da quantidade ideal de dilatação dos canais radiculares curvos, aludindo para as instruções pioneiras de Clem (1969) e Weine (1982), Melo \& Sydney (1990) dispõem que o término do preparo ao nível do forame apical com um instrumento de diâmetro \#25 não pode ser adotado como uma regra fixa. Consideram que a priori não é possível estabelecer este ou qualquer outro diâmetro como parâmetro definitivo na ampliação dos canais radiculares curvos e nem tampouco orientar-se no sentido de que se usem mais 3 ou 4 instrumentos, nos casos de polpa viva e polpa morta respectivamente, além do instrumento inicial. A técnica sugerida pelos autores prescreve uma odontometria dinâmica e emprego de duas limas novas de mesmo diâmetro dos \#08 ao \#25-\#30, podendo lançar-se mão de brocas Gates-Glidden, Peeso ou alargadores mecânicos para a dilatação da região cervical do canal. Segundo os autores, a partir de $30^{\circ}$ de curvatura a dificuldade no preparo de canais radiculares curvos torna-se marcadamente aumentada.

Em 1990 Bastos Filho et al. realizaram uma investigação in vitro da variação angular e da configuração apical, ou seja, retificação e modelagem quando do preparo de canais curvos com instrumentos de tipo e procedência variados. Para tanto empregaram raízes mésio vestibulares de 40 primeiros molares superiores e os seguintes instrumentos: lima tipo K da Kerr; lima tipo K da Maillefer; lima K-Flex da Kerr e lima Flexo-File da Maillefer. Os resultados mostraram que o grau de curvatura varia em função do tipo de instrumento usado: (i) a lima Flexo-File produziu a maior variação angular (ii) 
as limas Flexo-File e K-Flex produziram variações angulares estatisticamente significantes em relação aos outros instrumentos mas não entre si; (iii) maior índice de desvio para a lima tipo K da Kerr, seguida da lima tipo K da Maillefer e da Flexo-File e (iv) as limas Flexo-File e K-Flex produziram os menores freqüências de desvio.

2.2 Do preparo automatizado do canal radicular

As primeiras referências ao uso de dispositivos primordialmente propostos para a instrumentação do canal em menor período de tempo segundo mediante a reprodução da cinemática utilizada com os instrumentos manuais surgiram na literatura científica norte-americana já por volta de fins do séc. XIX. Com o tempo o emprego das brocas Peeso, Largo-Peeso e Gates-Glidden para a dilatação das regiões mais cervicais dos canais radiculares, com vistas a um acesso facilitado às regiões mais apicais especialmente em raízes curvas e canais estreitos, tornou-se amplamente difundido.

A partir do lançamento do Racer na década de cinqüenta, do Giromatic na década de sessenta e do surgimento do ultra-som como novo recurso para o preparo dos canais radiculares nos anos oitenta, as décadas mais recentes trouxeram uma série de aparelhos acionados a ar comprimido ou motor elétrico para o preparo automatizado dos canais com instrumentos mais 
flexíveis, em decorrência das novas ligas utilizadas na sua fabricação, e dotados de características geométricas diferentes das estabelecidas em anos anteriores. Surge também o LASER que ainda não consegue interagir de forma adequada com a configuração interna do sistema de canais radiculares e que, portanto, demanda investigação.

\subsubsection{Da investigação}

As primeiras evidências da utilização de instrumentos endodônticos acionados por motor para o preparo de canais radiculares datam do final séc. XIX quando do emprego de brocas Gates-Glidden por clínicos norte-americanos. Segundo Estrela et al. (1992) em 1894 Callahan já propunha o uso de brocas Gates-Glidden para facilitar a abertura dos canais radiculares. Em 1945 empregavam-se limas e alargadores acionados por peças de mão como o Giromatic (Micro-Mega) e o Racer (W\&H, Áustria). No entanto, o grande número de deformações dos canais radiculares preparados com limas ou alargadores de aço inoxidável como conseqüência, principalmente da rigidez e pequena flexibilidade destes instrumentos assim como de suas características de conicidade, acabaram por fazê-los cair em desuso (Pécora et al., 2000).

Embora Rollins já em 1899, de acordo com Beer et al. (1998a), tenha criado uma broca para canais radiculares acionada por motor dental(sic) a 
uma velocidade de 100rpm, somente com o surgimento da peça de mão Racer (Endolift) em 1958 e do contra-ângulo Giromatic (Micromega) em 1964 é que se inaugura a fase de preparo mecânico do canal radicular. Destes últimos, no primeiro o instrumento atuava em movimentos lineares enquanto que no segundo em movimentos recíprocos de $1 / 4$ de volta. Posteriormente surgiram novos dispositivos, e.g. Endo 3LD, Endolift 1, desenvolvendo cinemáticas que buscavam uma melhor reprodução dos movimentos do instrumento no preparo manual.

O uso de instrumentos rotatórios para uso intracanal é quase tão antigo quanto os instrumentos manuais, e Otollengui (1982) e Callahan (1894) já relatavam o uso de brocas como auxiliares no preparo dos condutos radiculares. Entretanto, apesar de disponíveis há mais de um século, as brocas de Gates-Glidden permaneceram muito tempo sendo usadas somente no preparo de espaço intra-radicular para ancoragem de pinos protéticos (Guerisoli et al., 1999).

Apesar de nesta fase as pesquisas gravitarem proeminentemente em torno da busca de uma definição das características de um preparo ideal do canal radicular com instrumentos manuais Mayer em 1965 publica um trabalho sobre as possíveis complicações do preparo de canais atresiados e curvos com Giromatic. Ao considerar as vantagens e desvantagens relacionadas ao preparo mecanizado do canal radicular com o referido dispositivo o pesquisador conclui que apesar deste tornar o preparo mais fácil e rápido, possíveis acidentes incluem a perfuração da raiz e a fratura do instrumento. 
Ainda neste mesmo ano, segundo Coffae \& Brilliant (1975), Büchs promove a análise histológica de canais radiculares após instrumentações manual e mecânica in vitro. Após descalcificação, seccionamento, coloração e quantificação microscópica do tecido pulpar remanescente pós preparo os resultados mostraram remoção tecidual inadequada independentemente do tipo de preparo realizado.

Jungmann et al. (1975), considerando os conceitos vigentes (Seidler, 1956; Heuer, 1963; Curson, 1966; Guttiérrez \& Garcia, 1968; Haga, 1968; Vessey, 1969 e Schneider, 1971) acerca do preparo do canal radicular, realizaram um experimento cujo propósito era a verificação do efeito da instrumentação em relação à forma final do canal radicular. Compuseram uma amostra de 150 molares inferiores e os espécimes do grupo controle não foram instrumentados. No segundo grupo um canal mesial foi instrumentado com lima e movimento de limagem e o outro com alargador e movimento de alargamento. No terceiro grupo um canal mesial foi preparado com limas e movimento de alargamento e o outro com Giromatic e alargadores. Em seguida os graus de curvatura das raízes foram registrados segundo o método proposto por Schneider em 1971 e estas foram preparadas conforme o método de Weine (1972) para limagem e alargamento. Após cortes transversais, as secções realizadas a 1,5mm e 6,0 $\mathrm{mm}$ do ápice radicular foram mensuradas através de microscopia e aumento de $40 x$ de tal forma que se obtivesse medidas do maior e do menor diâmetro de cada canal. Os autores concluíram que nenhuma técnica ou instrumentação poderá presumivelmente produzir um preparo circular na região apical e que em 
direção cervical a forma do preparo torna-se cada vez mais irregular. $\mathrm{O}$ alargamento com limas tipo K produziu as formas mais circulares seguido pelo alargamento com Giromatic e pelo alargamento com alargador. A limagem com limas tipo $\mathrm{K}$ produziu os preparos menos circulares.

Brilliant \& Christie (1975), de acordo com Fava (1984), propuseram a Serialization (Técnica de Serialização), a partir de um artigo publicado que descrevia o emprego da mesma no preparo de um incisivo lateral superior: após a determinação do CRT e instrumentação até a lima \#30 sob copiosa irrigação, inicia-se o processo de serialização. Procede-se, então, ao emprego de brocas Gates-Glidden \#2 (\#3 ou \#4 dependendo do diâmetro do canal) em comprimento menor que o CRT, lima \#35 até \#50 no CRT até encontrar-se dentina sã, dura e limpa. Em seguida instrumentação concluída com lima \#80 em comprimento menor que o CRT, concluindo-se o preparo com lima \#55 ao nível do CRT.

No mesmo ano, 1975, Coffae \& Brilliant enveredaramm por uma linha de pesquisa ligeiramente diferente ao analisarem a capacidade de remoção tecidual, não mais em relação a forma final, comparando a Técnica Convencional (Preparo Não Seriado) vs. Técnica Seriada (Preparo Escalonado). O propósito deste estudo teve como base as seguintes considerações: a afirmação de Weine (1972) de que qualquer material obtura o canal de forma bem sucedida quando este é bem preparado e a de Nygaard-Östby (1971) de que uma obturação adequada depende de um completo alargamento, a parte mais importante da desinfecção do canal, assim como os resultados dos trabalhos de Büchs (1965), Guttiérrez \& Garcia 
(1968), Senia (1971) e Davis et al. (1972) que de uma forma geral mostram o canal radicular repleto de irregularidades após a conclusão da fase de preparo sem remoção adequada do conteúdo dos mesmos. O experimento foi realizado empregando-se 56 molares inferiores recém extraídos que foram divididos em três grupos experimentais. No primeiro grupo experimental os canais mesiais receberam preparação não seriada até a lima ou \#30 ou \#35, sendo 5 dentes irrigados com água e 21 com soda clorada duplamente concentrada. No segundo grupo os canais foram preparados de forma seriada até uma lima \#60 após o que empregavam-se brocas Gates-Glidden \#2 e \#3 de $13 \mathrm{~mm}$ a $15 \mathrm{~mm}$ de profundidade sob o mesmo regime de irrigação usado com o primeiro grupo. No terceiro grupo após a confirmação da presença de tecido pulpar no interior da câmara coronária os canais não foram instrumentados e estes espécimes foram designados como grupo controle. Após o processamento das raízes mesiais para fins de análise histológica procedeu-se à quantificação do tecido pulpar remanescente. Os resultados mostraram que o preparo seriado foi significativamente mais eficiente na remoção de tecido que o preparo não seriado em quaisquer dos três níveis $(1 \mathrm{~mm}, 3 \mathrm{~mm}$ e $5 \mathrm{~mm})$ avaliados e que por outro lado, quando da presença de istmos, os primeiros não se apresentavam significativamente mais limpos que os últimos.

Klayman \& Brilliant, 1975, compararam a eficácia do preparo seriado vs. o preparo mecanizado com Giromatic (Micro-Mega, S. S. White Co., Philadelphia-PA, USA) empregando 100 canais radiculares de molares humanos extraídos. No grupo experimental I, composto de 25 dentes, os 
canais receberam preparo seriado com limas e brocas de Gates-Glidden \#2 e \#3 e que foi finalizado a $0,5 \mathrm{~mm}$ do ápice com uma lima \#70. O segundo grupo, 25 dentes, o preparo mecanizado com Giromatic foi concluído com um alargador Giro \#40. Os espécimes do grupo III, 15 dentes, foram usados como controle de tal forma que após a cirurgia de acesso apenas confirmou-se a presença de tecido pulpar no interior dos canais radiculares. Todos os canais instrumentados foram irrigados com solução salina. Após a conclusão do preparo, as raízes mesiais foram separadas dos dentes e seccionadas a $1 \mathrm{~mm}, 3 \mathrm{~mm}$ e $5 \mathrm{~mm}$ do ápice radicular, coradas e examinadas sob microscopia de luz de baixa potência. Os autores concluíram que o preparo seriado é mais efetivo que o preparo com Giromatic na remoção de tecido do interior dos canais radiculares mas que, no entanto, nenhum deles é totalmente efetivo na remoção de tecido do canal ou de istmos. Concluem também que não removem tecido na região apical tão efetivamente como o fazem na região coronária do canal.

Em 1976, Weine et al. ao tecerem considerações acerca do preparo mecanizado do canal radicular observam que em uma tentativa de se minimizar o tempo operatório e simplificar o preparo do canal radicular peças de mão estavam sendo desenvolvidas. Dentro deste contexto citam Harty \& Stock (1974) que relataram uma diminuição do tempo operatório com o emprego do Giromatic; Hasegawa et al. (1975) uma diminuição da fadiga do operador com o preparo automatizado e Frank (1967) e Fromme et al. (1972) uma menor freqüência de acidentes decorrentes da instrumentação dos canais radicualres. No entanto, conclusões divergentes são citadas a partir do 
trabalho de O'Connell \& Brayton (1975) que ao compararem a instrumentação convencional do canal radicular com o preparo com dois diferentes sistemas mecânicos julgaram a primeira forma superior á segunda para a qual não indicaram vantagem com relação ao tempo de trabalho. Diante destes pressupostos os autores empreenderam um experimento cujo propósito consistia em se verificar o efeito do preparo mecanizado sobre a forma original de canais radiculares. Para tanto avaliaram quatro diferentes métodos de preparo amplamente difundidos, i.e., (i) preparo com Giromatic (Micro Mega, S. S. White Co., Philadelphia USA, fornecido pelo suíço Dr. Angelo Sargenti) segundo instruções do fabricante, (ii) preparo mecanizado com o contra-ângulo W\&H (Pfingst and Co., New York) segundo instruções do fabricante, (iii) alargamento e (iv) escalonamento com instrumentos modificados através da remoção das espiras finais externas à curvatura como recomendado por Weine et al. (1975). Para este experimento empregaram canais curvos simulados confeccionados em blocos de resina e dentes extraídos. Em relação ao tempo de trabalho o alargamento correspondeu à técnica mais eficiente para o preparo dos canais radiculares. Entre os métodos testados o preparo com o contra ângulo $\mathrm{W} \& \mathrm{H}$ foi o que demandou maior tempo além de criar em alguns canais degraus que não puderam ser ultrapassados. Entre as peças de mão testadas nenhuma foi capaz de ultrapassar degraus intencionalmente produzidos. O tamanho dos zips (dilacerações apicais), ao nível do orifício de saída do canal, foi grandemente minimizado em canais acentuadamente curvos através do preparo 
escalonado e da remoção das espiras finais da face externa da curvatura de instrumentos pré curvados.

Por volta de 1978, um dos professores do Departamento de Endodontia do Departamento de Saúde da Universidade de Oregon (USA), chefiado pelo Dr. F. James Marshall, o Prof. John B. Pappin desenvolveu uma técnica de preparo dos canais radiculares atraumática para os tecidos periapicais, a Crown-Down Pressureless Preparation (Preparação Coroa-Ápice Sem Pressão) que consistia basicamente no acesso coronário, acesso radicular, preparo da matriz apical e posicionamento da parada(sic) apical De Deus (1986).

Weller et al., 1980, realiza um experimento cuja proposta consistia na comparação do debridamento em canais simulados em blocos de resina com canais de dentes naturais inovando quanto à metodologia de pesquisa e ao método de preparo dos canais radiculares. Usando ${ }^{123}$ (lodo) como isótopo radioativo em gelatina de Albumina, os autores quantificaram o debridamento promovido por três diferentes formas de preparo: instrumentação manual, preparo com ultra-som e sonda modificada e em terceira instância uma combinação destes. Após o preenchimento dos canais com a gelatina de radioisótopo, a perda de radioatividade foi medida após a conclusão do preparo. Não foram observadas diferenças estatisticamente significante quando da comparação entre os grupos instrumentados manualmente com os instrumentados com ultra-som, isoladamente. O preparo combinado com o uso de ultra-som após o preparo manual mostrou-se o método de preparo mais eficiente vistas as maiores reduções de radioatividade. 
Considerando que o recente difundido emprego da gutta-percha como material obturador condensada lateral e verticalmente resultou em alterações definitivas na forma a ser estabelecida pelo preparo dos canais radiculares, devido à dificuldade de manipulação deste material, Abou-Rass et al. publicam em 1980 um artigo contemplando a questão do preparo dos canais radiculares curvos e atresiados e proclamando o que denominam Anticurvature Filing (Preparo Anti Curvatura). O princípio básico do método consiste em uma melhor exploração da bulky or safety zone (região radicular mais volumosa ou segura), ao nível da curvatura e durante a instrumentação, em detrimento da manipulação da área mais frágil ou danger zone (zona de perigo). A manipulação inadvertida desta última, vulnerável por conta do volume da massa dentinária, poderia em função de seu adelgaçamento perfurá-la. Para tanto, a cirurgia de acesso torna-se um processo dinâmico ou funcional uma vez que desgastes coronários em qualquer momento do tratamento tornem-se convenientes para o preparo do canal na medida em que o instrumento possa atingir mais livremente a região apical do canal e se minimize o torque. A técnica prescreve a inserção de uma lima \#15 no interior do canal radicular e subsequente tomada radiográfica, para verificação da direção de instrumentação, preparo da terço apical, desgaste do terço cervical com broca de Peeso \#1 ou \#2 a uma profundidade de no máximo $3 \mathrm{~mm}$ e recapitulação com instrumento manual. Dessa forma advogam que a técnica mantém a integridade das paredes do canal em suas regiões mais delgadas, reduz a possibilidade de perfuração ou rasgo da raiz e permite um melhor controle cinestésico por parte do operador. 
Abou-Rass \& Jastrab em 1982 considerando que a forma obtida por Coffae \& Brilliant (1975), através da superioridade do preparo escalonado em relação ao preparo não seriado, pode ser efetivamente alcançada com o uso de brocas de Peeso e Gates-Glidden na entrada e terço cervical do canal radicular questionam se as brocas de Peeso \#1 e Gates-Glidden \#1 constituem recursos auxiliares efetivos na instrumentação manual do canal melhorando a qualidade do preparo e minimizando o tempo de trabalho. Para tanto usam-se de 100 molares de adultos humanos e recém-extraídos, 292 canais, distribuídos em 4 grupos (25 dentes cada) experimentais segundo a forma de preparo: Grupo 1 - preparo não seriado e após o último instrumento escalonamento nos terços médio e cervical; Grupo 2 - preparo não seriado e broca de Peeso \#1 ligeiramente aquém do início da curvatura; Grupo 3 preparo não seriado e broca de Gates-Glidden \#1 e Grupo 4 - preparo mecanizado com Giromatic. Os resultados mostraram que o Giromatic produziu preparo irregulares e que apesar de ter requerido menor tempo de trabalho produziu o maior número de erros operacionais na forma de compactação de debris e desvios (degraus e perfurações). Os autores observaram que apesar da instrumentação com limas tipo $K$ resultar na ocorrência de poucos erros esta não foi capaz de produzir formas de preparo bem definidas. Constataram que tanto as brocas Peeso \#1 e Gates-Glidden \#1, como recursos auxiliares no alargamento do terço cervical durante o preparo dos canais radiculares, além de terem melhorado efetivamente a qualidade do preparo também minimizaram significativamente o tempo de trabalho. 
Ainda neste mesmo ano, 1982, e dentro do contexto do preparo com instrumentos rotatórios, Abou-Rass et al. realizaram um trabalho para a verificação da espessura de dentina remanescente e ocorrência de perfurações nos terços cervical e médio dos canais radiculares de raízes de 150 molares superiores e inferiores após o preparo para retentor intrarradicular com brocas Largo-Peeso \#2, \#3 e \#4. Concluíram que as paredes distais dos canais mesiais de molares inferiores são delgadas e devem ser evitadas quando da seleção de raiz para retenção de pino. Segundo os autores as paredes proximais das raízes vestibulares dos molares superiores são regiões comuns de adelgaçamento e perfuração. Dessa forma concluíram que as raízes palatinas dos molares superiores e as distais dos inferiores são as mais indicadas para receberem retentores intrarradiculares desde que preparadas com brocas Largo-Peeso \#2 e \#3 ao nível de $7 \mathrm{~mm}$ além da entrada do canal.

Também em 1982 Turek \& Langeland compararam, sob microscopia de luz, a eficiência dos preparos dos canais radiculares telescópico e com Giromatic. Para tanto, usaram como critério a quantidade de tecido pulpar, pré dentina e debris removidos de dentes humanos in situ, dentes humanos recém extraídos e dentes de macacos. A investigação teve como proposta a avaliação das reivindicações dos fabricantes do Giromatic sobre sua eficiência e superioridade em relação ao preparo manual, v.g. o preparo telescópico, assim como a avaliação da influência dos aspectos anatômicos e anatomopatológicos dos canais radiculares em relação às referidas técnicas. Observaram que nenhuma das técnicas removeu tecido de forma efetiva e a 
análise estatística revelou resultados mais favoráveis com a técnica telescópica.

Goerig et al. publicaram um artigo em 1982 no qual descreviam o que denominavam step-down technique. Segundo os autores o tratamento endodôntico de qualquer dente pode ser dividido em três processos: o acesso coronário, o acesso radicular (técnica step-down) e a instrumentação apical (técnica step-back). A técnica prescreve que após a conclusão da cirurgia de acesso promova-se um desgaste compensatório (com broca esférica \#4) na parede oposta à da curvatura na região coronária, até os orifícios de entrada dos canais radiculares, de tal forma que essa retificação permita que o instrumento penetre o canal sem interferências. Em seguida procede-se à instrumentação dos terços médio e cervical do canal, o step-down para acesso radicular, empregando-se limas Hedströen (\#15 a \#25, de 16mm a 18mm), broca Gates-Glidden \#2 (de $14 \mathrm{~mm}$ a $16 \mathrm{~mm}$ ) e broca de Gates-Glidden \#3 (de 11mm a 13mm). Então após a determinação do CRT procede-se ao preparo escalonado (step-back) do terço apical do canal, usando-se uma lima tipo $\mathrm{K} \# 25$ como instrumento de recapitulação, de forma que o preparo apical seja realizado com uma lima tipo $\mathrm{K} \# 30$ ou \#35 uma vez que instrumentos de maior calibre poderiam facilmente promover degraus ou perfurações.

Fava em 1983 prescreve o Preparo Biomecânico Biescalonado(sic) como uma alternativa para o Preparo Escalonado. A indica para os casos de canais radiculares retos ou porções retas de canais curvos de dentes com rizogênese completa a contra-indicando para canais calcificados e dentes 
permanentes jovens ou com ápice aberto uma vez que estes últimos apresentam paredes dentinárias muito delgadas. Segundo o autor enquanto há alguns anos adaptava-se o canal radicular aos instrumentos endodônticos, hoje adaptamos nossos instrumentos endodônticos ao sistema de canais radiculares. Considera ainda que apesar das comprovadas vantagens do preparo escalonado em relação à técnica convencional, a filosofia do preparo biomecânico dos canais radiculares tem mudado. Baseia a abordagem inicial do terços cervical e médio com instrumentos de grande calibre nas conclusões de Shovelton (1964) de que a maior parte dos microorganismos encontra-se nestas regiões do canal radicular. De acordo com pesquisador autor a proposta também respalda-se nas conclusões de Chapman (1971), que observou que tantos os alargadores como as limas tipo $\mathrm{K}$ produzem extrusão de material para além do forame apical, e de Hession (1977) segundo o qual a lima atua como um pistão promovendo pressão hidrostática em direção apical que se excessiva promove a extrusão de material necrótico para a região periapical mas pode ser evitada com a divergência das paredes do canal. Para esta técnica empregam-se exclusivamente instrumentos manuais. Em uma primeira etapa procede-se ao preparo das regiões cervical e média dos canais radiculares com instrumentos de diâmetros gradativamente menores, a partir da lima \#80, objetivando-se a neutralização do conteúdo do canal. Em seguida continua-se com o avanço progressivo apical usando-se de instrumentos de menor calibre até que se atinja o CRT. Então procede-se ao preparo escalonado proposto por Weine em 1972. 
Cymerman et al., 1983, compararam através de MEV as técnicas manual e ultra-sônica quanto à eficiência no preparo de canais radiculares de 12 dentes recém extraídos. O primeiro grupo experimental composto de 6 dentes foi instrumentado com limas tipo $\mathrm{K}$, o segundo grupo também composto de 6 dentes foi preparado com PR-30 (Cavitron, Long Island City, NY, USA) e um terceiro grupo de 6 dentes foi designado como controle. Realizaram as seguintes observações: (i) alguns dentes controle não instrumentados apresentavam tecidos pulpar e dentinário facilmente observáveis enquanto outros pequena quantidade de tecido e túbulos dentinários expostos, (ii) as duas formas de preparo produziram paredes do canal irregulares e impregnadas de magma e (iii) não houve diferença estatisticamente significante quanto à aparência das paredes dos canais comparados os métodos de preparo utilizados.

Kessler et al. (1983) compararam o risco de perfuração de raízes de molares durante a instrumentação de canais mesiais em função de cinco diferentes técnicas de preparo. Segundo os autores, de acordo com Ingle \& Beveridge (1976), é possível estabelecer uma analogia entre a Dentística e a Endodontia - enquanto na primeira o ideal seria a remoção dos tecidos doentes e o selamento permanente da cavidade com um material inerte, o ideal da Endodontia seria a remoção do tecido pulpar doente e o selamento do sistema de canais radiculares com um material inerte e, em maior extensão, o preparo escalonado do canal radicular poderia ser comparado à forma de conveniência dada ao preparo cavitário. Constitui-se uma amostra representativa composta de 60 dentes, primeiros e segundo molares 
humanos, que após terem suas faces oclusais aplainadas foram abertos segundo Cohen \& Burns (1980). Os espécimes foram distribuídos em 3 grupos experimentais, 20 dentes cada, e irrigados com soda clorada durante toda a fase de preparo. No Grupo 1, o Grupo Controle, 20 canais (Grupo 1A) não foram instrumentados e os outros 20 (Grupo 1B) foram instrumentados por uma técnica padrão, em toda sua extensão circunferencial até o calibre de \#35, sem escalonamento adicional da região cervical do canal. No Grupo 2, os canais foram instrumentados, manualmente, através da Técnica Escalonada (Preparo Seriado): até um instrumento \#35 ao nível do CRT e em seguida com recuos de $1 / 2 \mathrm{~mm}$ até um instrumento \#60 e finalização com escalonamento do terço cervical com uma lima Hedstroëm \#60. Cada canal do Grupo 2A foi instrumentado cirucunferencialmente e os canais do Grupo 2B receberam Preparo Anti Curvatura como descrito por Abou-Rass et al. (1980). No grupo controle, 20 dentes (Grupo 1A) não foram instrumentados e outros 20 dentes (Grupo 1B) foram instrumentados circunferencialmente até o tamanho \#35). No Grupo 3 os dentes foram preparados através de escalonamento mecanizado: os canais foram preparados pela Técnica Seriada como o Grupo 2 complementando-se o preparo da região cervical através de escalonamento mecanizado. Os 20 canais mesiais do Grupo 3A foram escalonados com brocas de Gates-Glidden \#2 e \#3 segundo a maneira descrita por Coffae \& Brilliant (1975) e Mullaney (1979). Os canais do Grupo 3B foram escalonados com brocas esféricas \#2 e \#4 segundo a Técnica Anti Curvatura. O experimento permitiu as seguintes observações: (i) na raiz mesial de molares inferiores o perigo de se adelgaçar ou perfurar a parede de dentina foi muito 
maior em direção à região da bifurcação, (ii) a espessura média de dentina remanescente em direção à bifurcação, após a conclusão do preparo, era significativamente maior com as técnicas escalonadas e anti curvatura, (iii) dos preparos com brocas esféricas e Gates-Glidden não resultaram paredes de dentina significativamente mais finas que dos preparos escalonados com instrumentos trabalhando circunferencialmente e (iv) os resultados parecem suportar a premissa de que se brocas são usadas para o escalonamento, estas deveriam ser usadas com a Técnica da Anti Curvatura. Segundo os pesquisadores conclui-se que com relação ao perigo de perfuração durante o preparo de raízes de molares, na região da bifurcação, a Técnica Anti Curvatura e a instrumentação manual são as mais seguras entre as técnicas de preparo escalonado. Das formas de preparo mecanizado, o emprego de brocas esféricas \#4 e \#2.

Em 1983 Leeb realizou um estudo para averiguar o efeito do alargamento do orifício de entrada do canal radicular antes do preparo biomecânico da região apical. Fazendo alusão às técnicas de preparo do canal radicular preconizadas pelas Universidades do Sul da Califórnia e de Ohio, que prescrevem o alargamento das regiões mais cervicais do canal, ao fato de que embora Schilder (1974) tenha enfatizado a necessidade de um preparo afunilado continuamente cônico não é claro se esta relaciona-se à requisitos de ordem biomecânica ou atendem à prescrições da técnica de obturação. Para o experimento foram selecionados molares superiores e inferiores extraídos, apresentando raízes curvas e ápices fechados, cujos canais foram preenchidos com tinta da Índia. Então após a remoção da tinta 
inseriu-se um instrumento manual de tal forma que sem forçá-lo este se ajustasse ao canal, observou-se a região do instrumento em que os sulcos traziam tinta. Em seguida os canais foram alargados com brocas de Gates-Glidden \#2, \#3 e \#4 ou brocas de Peeso \#1, \#2 e \#3, após o que observou-se a região de um instrumento inserido sem força em que os sulcos traziam tinta. $O$ autor observou que os canais mesiais de molares normalmente apresentam uma curvatura distal ao nível do terço cervical, que a aposição normal de dentina torna a região cervical a mais estreita do canal radicular promovendo uma deflexão do instrumento e que o alargamento do orifício de entrada antes da instrumentação elimina esta interferência e a facilita. O experimento permitiu concluir que a broca de Peezo foi o melhor recurso para a eliminação desta interferência.

Baseados na técnica descrita por Bence em 1976, Canzani et al. realizaram em 1984 um trabalho para comparar, em função da quantidade de tinta removida do interior de canais radiculares, a eficiência do preparo mecanizado em relação à técnica de preparo seriado. Empregaram 30 dentes unirradiculares extraídos. O Grupo 1 foi composto de 10 espécimes usados como controle. Os 10 dentes do Grupo 2 foram preparados utilizando-se uma Técnica Escalonada com limas tipo K com recuo progressivo e recapitulação a partir do momento em que julgou-se o terço apical preparado. No Grupo 3, 10 dentes, após o alargamento da região cervical do canal com brocas Largo (Maillefer S.A.) \#1 e \#2 concluiu-se o preparo com instrumentos manuais. Dos dados obtidos pode-se inferir que com o uso de brocas Largo obtém-se resultados significativamente superiores de limpeza dos condutos com 
respeito ao uso de instrumentos manuais isoladamente, independentemente da técnica para o emprego das mesmas.

Em 1984, o Professor Lévy, da Faculdade de Odontologia de Marseille, França, ao apresentar o Canal Finder para o preparo mecanizado de canais radiculares, considera o tratamento endodôntico como uma das intervenções mais incertas da Odontologia devido à dificuldades que se explicam pelo seguinte: a anatomia do canal radicular é bastante variável tornando o cateterismo(sic) extremamente constrangedor(sic) para o operador; os instrumentos fraturados podem comprometer definitivamente o futuro do órgão dental e a repetição fastidiosa das manobras operatórias durante 0 preparo. Segundo o pesquisador sua nova invenção realiza um cateterismo mecânico quaisquer que sejam a direção, o ângulo ou diâmetro do canal radicular; promove uma forma de preparo harmônica porque a realiza dentro de um senso lógico; permite a obturação através da condensação da gutta-percha e é confiável pois não promove falhas de preparo e fraturas de instrumento além de reduzir o tempo de trabalho. $\mathrm{O}$ aparelho consiste num contra-ângulo, para micro motor ou peça de mão, destinado a um movimento especial duplo com limas tipo $\mathrm{K}$ ou Hedströem. O movimento de rotação é auto limitado pelas espiras do instrumento, os movimentos ao longo do eixo longitudinal são controlados pelo operador através da limitação da velocidade.

Goodman et al. compararam in vitro, em 1985, a eficiência da Técnica Escalonada vs. a associação da Técnica Escalonada com o Preparo Ultra-sônico quanto a remoção tecidual de canais mesiais de 60 molares inferiores humanos extraídos. Os dentes foram selecionados aleatoriamente e 
divididos em três grupos experimentais. No Grupo I, após a determinação do CRT, os 20 espécimes foram instrumentados com limas tipo $\mathrm{K}$ e brocas Gates-Glidden \#2 e \#3. Os 20 espécimes do Grupo II receberam o preparo do Grupo I que foi complementado através da ação de um aparelho de ultra-som piezoelétrico Buffalo Modelo S-40 (Buffalo Dental Mfg., Brooklyn, NY, USA) a uma freqüência de 40.000 ciclos/seg. Os 20 espécimes remanescentes constituíram o Grupo Controle que, após a confirmação da presença de tecido pulpar, não foram instrumentados. Após o processamento histológico, projeção das imagens e demarcação do contorno de cada canal, istmo e tecido pulpar remanescente usou-se um planímetro para mensuração do percentual de tecido removido. O preparo escalonamento/ultra-som foi significativamente mais eficiente na limpeza dos istmos ao nível de $1 \mathrm{~mm}$ mas não a 3mm. Não se observou diferenças significantes entre o Grupo I, Preparo Escalonado, e o Grupo Controle em ambos os níveis. Em ambos os grupos experimentais não se observou diferenças significativas de limpeza ao nível de $1 \mathrm{~mm}$ quando da comparação entre os operadores.

Ao estabelecerem um estudo preliminar comparando aparelhos sônico e ultra-sônico com respeito a redução do tempo de trabalho, Langeland et al. (1985) concluíram que a despeito do método empregado nenhum limpou completamente, mediante a análise histológica, 35 dentes humanos recém extraídos (do Grupo I com um total de 65 dentes) e 10 dentes de macacos (preparados in situ de uma amostra de 106 dentes, Grupo II). Observaram que tanto a instrumentação manual como as instrumentações sõnica/ultra-sônica limparam canais retos circulares e que nenhuma delas limpou canais curvos 
ou irregulares. Verificou-se que a morfologia do canal e a presença de patologias era muito mais importante que o tipo de aparelho usado e que, sob circunstâncias similares, poderia realizar-se um preparo muito mais rápido e menos estressante com os aparelhos sônico/ultra-sônico. Por outro lado, a eficiência aumentada implicava em cuidado para prevenir-se perfuração radicular.

Lim \& Stock, em 1987, realizaram um estudo cuja proposta era examinar a zona de perigo e avaliar a efetividade da Técnica Anti Curvatura, descrita por Abou-Rass et al. em 1980, na redução do risco de perfuração radicular. A partir de uma amostra composta de 71 primeiros e segundos molares humanos asiáticos recém extraídos, no Grupo Experimental I 30 canais mesiais foram preparados com a Técnica Escalonada Ápico-Cervical, acorde Harty (1982) e no Grupo II os canais foram preparados usando-se a Técnica Anti Curvatura padrão, de tal forma que a cada vez que a parede distal (voltada para a furca) fosse instrumentada cada uma das outras paredes (vestibular, lingual e mesial) era instrumentada 3 vezes a partir da lima \#35 a 3mm ápice. Segundo os pesquisadores, dentro dos limites experimentais, do estudo pode-se inferir as seguintes conclusões: (i) a curvatura média das raízes mesiais dos molares inferiores era de $24,9^{\circ}$; (ii) nas raízes mesiais de molares inferiores, os canais não preparados estão ligeiramente mais próximos da região da furca tanto a $5 \mathrm{~mm}$ como a $8 \mathrm{~mm}$; (iii) após a conclusão do preparo quantidade substancialmente maior de dentina foi removida da parede distal (furca) em relação à mesial, ao nível de $8 \mathrm{~mm}$. No entanto, não houve diferença significante ao nível de $5 \mathrm{~mm}$; (iv) o risco de 
perfuração tanto com a Técnica de Preparo Escalonado Ápico-Cervical como com a Técnica Anti Curvatura era muito maior em relação à parede distal do canal mesial a $8 \mathrm{~mm}$ que a $5 \mathrm{~mm}$ do ápice; houve o rico de rasgar ou perfurar a parede distal a $8 \mathrm{~mm}$ em $36 \%$ dos canais preparados pela Técnica Escalonada; (v) a Técnica Anti Curvatura preservou uma maior espessura de dentina remanescente que a Técnica Escalonada, reduzindo o risco de perfuração da raiz e este resultado foi estatisticamente significante e (vi) não encontrou-se qualquer correlação entre o grau de perfuração e o risco de perfuração.

Spyropoulos et al., 1987, realizaram um estudo para determinar o efeito do preparo com Giromatic sobre a morfologia interna de canais simulados. Considerando os resultados divergentes dos experimentos até então relatados, com relação ao tempo de trabalho, acerca do preparo mecanizado com instrumentos em movimentos recíprocos, os autores fazem referência à sugestão de Ingle \& Taintor (1985) para os quais a experiência insatisfatória quando da introdução do Giromatic deveu-se ao tipo de instrumento com o qual este era usado. Após a confecção de 200 blocos de resina de polyester, como descrito por EIDeeb \& Boraas (1985), mas criando-se um canal mestre com uma lima \#15 curvada em $45^{\circ}$ no terço apical, de acordo com Weine (1982) e Hanske (1982). Após a determinação do CRT os primeiros 2mm de cada canal foram alargados com uma broca Gates-Glidden \#2. Os blocos foram distribuídos aleatoriamente em 5 grupos experimentais, 40 blocos cada, de acordo com a técnica de preparo utilizada: (i) Giromatic (Micro Mega, Besançon, França) com limas Dynatrac (Ransom and Randolph, Dentsply, 
Toledo, Ohio, USA); (ii) Giromatic (Micro Mega, Besançon, França) com limas Trio-Cut (Medidenta International Inc., Woodside, New York, USA); (iii) preparo manual com limas Trio-Cut (Medidenta International Inc., Woodside, New York, USA); (iv) preparo manual com limas Burns Unifile (Ransom \& Randolph, Dentisply, Toledo, Ohio, USA) e (v) preparo manual com limas Hedstroëm (Union Broach Co., Long Island City, New York, USA). O contra ângulo Giromatic foi usado em 3000 rev/min, irrigados com Glyoxide inclusive na recapitulação. A análise do preparo incluiu a checagem de degraus, perfuração, forma em ampulheta e fratura de instrumento e mensuração do diâmetro do canal, após o preparo com instrumento \#35, em 1mm, 2mm, 4mm e 8mm a partir do ápice. A comparação do preparo manual vs. preparo com Giromatic mostrou: (i) não houve diferenças significante no número de defeitos produzidos tanto pelo preparo manual como pelo preparo com Giromatic com limas Trio-Cut, exceto com as limas \#35; (ii) a instrumentação com Giromatic produziu preparos apicais mais amplos; (iii) a instrumentação manual produziu preparos mais afunilados e (iv) não houve diferença significante quanto ao tempo de preparo. O preparo com limas Hedstroëm apresentou a menor quantidade de defeitos, as formas mais afuniladas e o menor consumo de tempo.

Em 1987, Reynolds et al. realizaram um experimento in vitro com dentes humanos recém extraídos comparando histologicamente 4 formas de preparo de 80 canais radiculares estreitos e curvos - Preparo Escalonado Ápico-Cervical, Preparo Sônico com Endostar 5, Preparo Ultra-Sônico com Cavi-Endo e com PZ-KTec - avaliando a quantidade de dentina e debris 
remanescentes, o percentual de aplainamento das paredes do canal e de aumento da área do canal. Os resultados não mostraram diferenças estatisticamente significantes entre os 4 métodos estudados.

No mesmo ano, Stamos et al. (1987), também realizaram um experimento in vitro para mensuração, através de observação histológica, da capacidade de debridamento dos métodos sônico (Cavi-Endo), ultra-sônico (ENAC) e manual de preparo dos canais mesiais de 50 molares inferiores. Dentre os métodos estudados o ENAC limpou significativamente um percentual maior de canais a $1 \mathrm{~mm}$ enquanto que o Cavi-endo foi o que maior percentual produziu a 3mm. Os métodos sônico e ultra-sônico foram os que mais rapidamente preparam os canais.

Goldman et al., 1987, empreenderam um estudo in vitro para verificar a capacidade de exploração de um novo dispositivo mecânico para o preparo de canais radiculares, o contra-ângulo SET (Societe Endo Technic, da Endo Technic Corp., Natick-MA, USA). Para tanto compararam o efeito dos preparos Convencional e com SET sobre as formas originais dos canais de 40 molares humanos extraídos. Os espécimes foram aleatoriamente divididos em 2 grupos experimentais cada qual com 20 raízes, incluídos em resina acrílica autopolimerizável, preparados e avaliados com lente de aumento $(x 7,8)$ para delimitação da áreas. Observou-se que na instrumentação mecânica com o contra-ângulo SET os instrumentos penetraram os canais curvos melhor adaptados que os instrumentos do tipo K. Os traçados sobre as radiografias permitiu a observação da discrepância entre as posições inicial e final do instrumento, ou seja, independentemente da forma de preparo 
verificou-se uma tendência de retificação do canal. Segundo os pesquisadores determinadas regiões do canal radicular não puderam ser instrumentadas como a princípio se acreditou.

Levy publicou em 1987 um outro artigo sobre o Sistema Canal Finder, no tratamento de canais curvos, no qual afirma que este recurso permite ao operador a realização de toda a operatória endodôntica, ou seja, a instrumentação e a obturação do canal radicular. Segundo o autor, uma vez que a conclusão do tratamento dependa da compactação da gutta-percha, é evidente que a qualidade desta depende do preparo propriamente dito. Dessa forma o preparo é realizado em função da técnica de obturação e em nenhum caso o diâmetro final de preparo ao nível do forame apical deve ser inferior ao de uma lima \#25. Também, a conicidade do preparo ao nível do terço cervical deve ser suficientemente ampla para permitir ao operador atuação efetiva nos terços médio e apical do canal radicular. Esta ampliação do terço cervical pode ser realizada com brocas Gates-Glidden e o desgaste ao nível dos terços médio em na direção das paredes mesial e vestibular de acordo com a Técnica Anti Curvatura.

Em um estudo de 1988, Haikel \& Allemann compararam com MEV a eficiência na remoção tecidual de quatro métodos de preparo do canal radicular: (i) preparo manual com limas tipo $\mathrm{K}$ e $\mathrm{H}$ alternadamente; (ii) preparo sônica com instrumentos Rispisonic e Helisonic; (iii) preparo sônica com instrumentos Shapersonic e (iv) preparo com Canal Finder System. Os resultados obtidos com o preparo manual foram similares aos obtidos com o CFS e os métodos sônicos promoveram uma melhor remoção de tecido nos 
terços cervical e médio que no terço apical. Os autores concluem que apesar dos métodos sônicos e CFS permitirem preparos mais rápidos apresentam maiores desvantagens em relação ao preparo manual, uma vez que os primeiros não preparam convenientemente o terço apical e o segundo tende a retificar o canal. Sugerem que uma vez que se opte pelo preparo mecanizado do canal radicular é aconselhável usar ou o CFS para o preparo de todo o canal ou, então, um dos métodos sônicos para o preparo dos terços cervical e médio em conjunção com o preparo manual do terço apical.

Em 1988, Walia et al. publicaram um artigo acerca de uma investigação inicial sobre as propriedades de deflexão e torção de limas Nitinol para o preparo de canais radiculares. Este trabalho introduz no panorama endodôntico um instrumento com características químicas e físicas totalmente diferentes dos instrumentos até então disponíveis. Os pesquisadores aludem para que os erros decorrentes do preparo dos canais curvos têm uma gênese comum: a dureza das ligas de Aço Inoxidável utilizadas para a fabricação de limas e alargadores além do aumento substancial da dureza em função direta dos aumentos progressivos no diâmetro dos mesmos. Então várias tentativas foram realizadas pelos fabricantes (como ligas de diferente composição química, diferentes métodos de fabricação, diferentes desenhos, etc.) para o uso mais seguro quanto à manutenção da forma original do canal radicular, para o aumento da flexibilidade e da capacidade de corte. Para esta investigação, através de um processo único de fabricação confeccionaram-se 5 limas \#15 a partir de segmentos retos, de fio ortodôntico Nitinol padrão, de 0.020pol. de diâmetro e 2 pol. de comprimento. Os instrumentos foram 
fabricados através de um processo de usinagem e com secção transversal triangular. Comparou-se os em testes de deflexão (em incrementos de $10^{\circ}$ até $90^{\circ}$ ) e torção (nos sentidos horário e anti-horário em incrementos de $45^{\circ}$ até $360^{\circ}$ e após em incrementos de $90^{\circ}$ até a fratura do instrumento) com 5 limas \#15 fabricadas da mesma forma e com a mesma secção transversal triangular a partir de Aço Inoxidável. Empregou-se MEV para a observação dos instrumentos após a fabricação e após a fratura nos testes de torção. As limas confeccionadas de Nitinol apresentaram um módulo de elasticidade três vezes maior que as limas confeccionadas em Aço Inoxidável, assim como uma resistência superior à fratura nos testes de torção. A flexibilidade extraordinária resulta dos baixos valores do módulo de elasticidade dos módulos de tensão e cisalhamento da liga de Nitinol e a superior resistência à fratura da ductilidade da liga de Níquel-Titânio.

Baker et al. (1988) compararam a instrumentação manual do canal radicular com o preparo ultra-sônico através de MEV. Não encontraram diferenças significativas quanto à presença de debris ou magma dentinário assim como em relação à túbulos desobstruídos ao nível dos terços cervical e apical. No entanto, ao nível médio, o preparo manual produziu paredes significativamente mais limpas.

Em 1989, Wildley \& Senia propuseram um novo instrumento e uma nova técnica para o preparo manual e mecanizado dos canais radiculares, o SW (Senia \& Wildley). O instrumento SW incorporava as três principais características: (i) manutenção das espiras da ponta do instrumento para a condução deste até o forame apical e conseqüente redução de desvios; (ii) 
redução da parte ativa do instrumento de $16 \mathrm{~mm}$ para $2,5 \mathrm{~mm}-4 \mathrm{~mm}$ e (iii) redução do diâmetro da haste para tornar o instrumento mais flexível. Os instrumentos SW 25 para o preparo manual do canal radicular, \#20 a \#80, foram obtidos da adaptação de limas tipo $\mathrm{K} \# 25$ da Kerr Manufacturing Company (Romulus, Michigan, USA). Os instrumentos a serem usados de forma automatizada, em peças de mão de baixa rotação nos tamanhos \#60 a \#80, foram confeccionados da adaptação de instrumentos rotatórios de $25 \mathrm{~mm}$ da Medidenta International Inc. (Woodside, New York, USA) em tamanhos próximos dos \#2, \#3 e \#4 das brocas Gates-Glidden que normalmente são empregados para o preparo da região cervical do canal. O SW utiliza-se de um sistema de controle de forças de rotação para a direita e para a esquerda e foi testado em canais simulados e dentes extraídos. As observações sugeriram um preparo mais fácil, mais rápido e mais preciso que o realizado com os instrumentos convencionais. Os instrumentos para serem utilizados em contra-ângulo o foram na dilatação da região cervical do canal.

Segundo Petschelt (1989) com nenhum dos métodos, manual ou mecânico, é possível preparar o canal radicular em toda sua extensão agindo sobre todas as paredes. Afirma que uma combinação do preparo manual com os métodos sônico e ultra-sônico ou mecânico certamente é vantajosa. Para o autor uma vez que, mais importante que decidir-se sobre preparo manual ou mecânico, é o preparo meticuloso e o conhecimento de anatomia do canal radicular por parte do operador.

Com vistas aos possíveis danos histológicos do periodonto de suporte durante os procedimentos de preparo do canal para retentor intrarradicular 
Saunders \& Saunders (1989) investigaram os aumentos de temperatura decorrentes do emprego da broca Gates-Glidden, instrumento rotatório GPX \#50, alargador rotatório PD \#3 e da broca Parapost \#3. Nas condições experimentais estabelecidas considerável aumento de temperatura se deu quando do emprego do alargador PD e da broca Parapost com excessos de até $10^{\circ} \mathrm{C}$. Dessa forma sugerem os autores que o preparo do canal para retentor intrarradicular seja realizado em duas etapas de tal que forma a remover-se a gutta-percha com brocas Gates-Glidden num primeiro momento e rotação manual de instrumentos num segundo momento.

Campos \& del Rio, 1990, compararam as formas original e pós-instrumentação de 12 canais mesiais curvos de molares humanos inferiores com as técnicas manual e automatizada. Além da mensuração da área de dentina removida também avaliou-se a quantidade e direção de transporte do forame apical em relação ao grau de curvatura da raiz. Os autores consideram que muitos métodos foram desenvolvidos para diminuição dos efeitos indesejáveis do preparo - o desvio, o degrau, a dilaceração-transporte e a perfuração radicular. As tentativas iniciais de adaptação de limas $(\mathrm{K} \mathrm{e} \mathrm{H})$ e a alargadores para serem utilizados no preparo mecanizado ou automatizado, em contra-ângulos como o Giromatic (Giro Micro-Mega S., Genéve, Switzerland), o $\mathrm{W}+\mathrm{H}$ (Dentalwork Buermoos Salzburg, Austria), o Canal Finder System (Endo Technique Corp., Newton, MA) e aparelhos sônicos e ultra-sônicos produziram instrumentos agressivos pois que com maior capacidade de corte assim como um aumento dos problemas relacionados ao desvio da forma original do canal. Para este 
experimento os pesquisadores empregaram 12 raízes (24 canais) mesiais de primeiros e segundos molares de adultos extraídos de humanos. As raízes apresentavam curvaturas que variavam entre $20^{\circ}$ e $30^{\circ}$ e foram radiografadas, destacadas dos dentes, incluídas em resina acrílica transparente, seccionadas transversalmente em três partes e distribuídas em 2 grupos experimentais: (i) no grupo 1, 12 canais, os espécimes foram instrumentados com Canal Finder System, segundo orientações do fabricante e de seu criador (Dr. Guy Levy) e limas Hedströem e (ii) no grupo 2, 12 canais, os espécimes foram instrumentados com limas K-Flex (Sybron Kerr) segundo Grossman (1988). As fotografias realizadas antes e após o preparo permitiram medidas de áreas do canal radicular e a diferença entre estas forneceu a área de dentina removida da periferia do canal ao nível dos terços cervical, médio e apical. Os resultados mostraram que o preparo mecanizado foi o que promoveu maiores remoção de dentina e desvio que o preparo manual, nos terços cervical e apical. Quanto à deformação da forma original do canal observou-se (i) com ambos os preparos, desvio em direção à parede distal na região cervical assim como em direção a parede mesial na região apical do canal radicular e (ii) no terço médio, o preparo automatizado produziu maior transporte em direção à parede mesial e o preparo manual em direção à distal. Os pesquisadores concluíram que o grau de curvatura do canal radicular não teve influência sobre a quantidade de dentina removida ou desvio da forma original do canal.

Novamente em 1990, Lévy publica novo artigo discorrendo sobre indicações e melhoras realizadas no sistema Canal Finder após quatro anos 
de experimentação e considerando que este corresponde ao único dispositivo para o tratamento endodôntico totalmente automatizado. Relata que em relação à versão de 1984 os problemas foram sanados através da substituição da antiga lima $\mathrm{K}$ por uma lima $\mathrm{H}$ que, a partir de uma melhor adaptação aos canais radiculares curvos, melhora a eficiência da instrumentação automatizada tornando-o mais confiável e fácil de ser usado.

Lopes \& Costa Filho, 1990, acerca do emprego da brocas Gates-Glidden e Largo sugeriram a seguinte técnica de preparo dos canais radiculares: (i) preparo apical - preparo do terço apical com limas a partir do \#8 ou \#10 até o \#20 ou \#25; (ii) preparo do corpo do canal radicular- emprego de forma seqüencial das brocas Gates-Glidden \#2, Largo \#1 e Gates-Glidden \#1; (iii) seqüência do preparo apical até as limas \#30-\#35 ou \#40; (iv) escalonamento ápico-cervical e (v) recapitulação. Segundo os autores o emprego das brocas referidas apresentam as seguintes vantagens: podem ser usadas em qualquer tipo de canal; acesso mais retilíneo e direto à região apical; possibilitam melhor limpeza e reduzem extrusão do conteúdo do canal; facilitam a irrigação-aspiração e a obturação; promovem preparo cilíndrico; facilitam procedimentos protéticos e reduzem o tempo de preparo.

Giles \& del Rio (1990) compararam, em canais curvos, o preparo do canal radicular com Canal Master com o preparo manual com limas tipo K. A despeito das várias técnicas propostas para o preparo dos canais curvos a questão da limpeza e da ação cêntrica do instrumento ainda permanece não solucionada. Dessa forma realizaram este experimento para investigar a capacidade do Canal Master e de limas tipo K em produzir preparos cêntricos. 
Para tanto 20 estudantes de Odontologia, sem experiência clínica endodôntica, prepararam 20 molares inferiores. Concluiu-se que a técnica de instrumentação com o Canal Master foi a que menos promoveu desvio do canal radicular e a que mais promoveu formas circunferenciais. Pareceu haver uma maior tendência de fratura do instrumento com o Canal Master.

Luebke \& Brantley (1991) realizaram um estudo laboratorial das brocas Gates-Glidden para a determinação de suas propriedades metalúrgicas e de torção. Amostras nos tamanhos de \#1 a \#6, de dois diferentes fabricantes foram distribuídas nos Estados Unidos e testadas sob torção incremental e contínua com um torquímetro digital. A análise dos resultados experimentais não demonstrou diferenças estatisticamente significantes quanto ao momento de fratura para um dado instrumento de um dada procedência. A MEV confirmou falhas de ductilidade que se tornaram visualmente evidentes após a fratura dos instrumento.

Saunders \& Saunders (1994) compararam os preparos dos canais de 51 primeiros molares inferiores ou superiores com limas Flexofile de ponta não modificada, pela Técnica de Força Balanceada (Roane, 1985), com os preparos realizados por limas Flexogates e Canal Master U, instrumentos de ponta modificada operados conforme instruções do fabricante. Todos os instrumentos foram empregados em uma seqüência de desgaste duplo (Double-Flared Technique) de tal forma a alargar-se a porção coronária do canal com brocas Gates-Glidden. As imagens radiográficas digitais dos espécimes, tomadas antes e após os preparos, analisadas com um programa de computador e moldagens intracanal foram usadas para a avaliação 
subjetiva da qualidade dos preparos e pesquisa de alterações dimensionais (área e diâmetro). Os resultados não demonstraram diferenças percentuais estatisticamente significantes quanto à variação de área do canal, mas as mostraram quanto à largura. Os três instrumentos mostraram-se eficiente no preparo dos canais radiculares mas a lima Canal Master $U$ teve um alto e inaceitável número de fraturas.

Lopes \& Aguiar, 1994, analisaram comparativamente o diâmetro cervical produzido pelo preparo com limas tipo $\mathrm{K}$ ou com brocas Gates-Glidden de diâmetros correspondentes. Utilizaram 40 caninos, dos quais 20 tiveram suas coroas removidas, que foram indistintamente instrumentados até a lima \#30 e em seguida divididos em quatro grupos experimentais: (a) Grupo 1: dez dentes com coroa foram preparados da forma convencional até a lima \#55; (b) Grupo 2: dez dentes com coroa foram preparados com brocas Gates-Glidden até a de \#3; (c) Grupo 3: dez dentes sem coroa foram preparados pela técnica convencional até a lima K \#55 e (d) dez dentes sem coroa foram preparados com brocas Gates-Glidden até a de \#3. Segundo os autores e de acordo com os fabricantes, a lima $\mathrm{K}$ tem $D_{1}=0,55 \mathrm{~mm}$ e $D_{2}=0,87$ enquanto a broca Gates-Glidden \#3 (Maillefer) 0,9mm, diâmetros comparativamente semelhantes. Os autores observaram as limas K produzirem maiores diâmetros cervicais, estatisticamente significantes, que as brocas Gates-Glidden correspondentes. Nas amostras sem coroa o diâmetro cervical foi maior, comparativamente, do que o das amostras com coroa. 
Brantley et al., 1994, estudando as características de fadiga de instrumentos rotatórios de aço quanto ao momento de fratura, registraram os números de revoluções por minuto em que brocas Gates-Glidden e Peeso, de aço inoxidável e aço-carbono, em movimento e sob deflexão experimental, fraturavam. A MEV revelou que tanto as brocas Gates-Glidden como as Peeso de aço inoxidável fraturaram devido à falhas de ductilidade enquanto que as brocas Peeso de aço-carbono fraturaram devido à falha de dureza e friabilidade. Verificaram que as fraturas normalmente ocorriam próximas à peça de mão.

Comparando preparos realizados com limas de aço inoxidável com limas manuais de níquel-titânio e instrumentos de níque-titânio, Esposito \& Cunningham (1995) observaram em seu experimento que as limas de níquel-titânio foram mais efetivas na manutenção do trajeto original do canal radicular de canais curvos além do instrumento \#30.

Tepel et al., 1995, estudaram a capacidade de corte de 24 instrumentos endodônticos manuais (instrumentos de níquel-titânio (lima K Mity, lima K NiTi, lima K Texceed) instrumentos de aço inoxidável (alargador Antaeos, lima K-file, lima Flexcut, alargador Brasseler, lima K Brasseler, alargador Kerr, lima K Kerr, lima K-Flex Kerr, alargador Maillefer, lima K Maillefer, alargador Flexoreamer Maillefer, alargador Flexoreamer Batt tip Maillefer, lima K-Flexofile Maillefer, lima K-Flexofile Batt tip Maillefer, alargador Meisinger, lima K Meisinger, alargador Micro Méga, alargador Roeko, lima K Roeko, e lima Flex-R Union Broach), em movimentos de alargamento no preparo de canais simulados curvos usando como critério de análise a profundidade dos 
preparos. As limas de níquel-titânio mostraram a menor capacidade de corte e os alargadores de aço inoxidável, e especialmente as limas $\mathrm{K}$, mostraram melhor capacidade de corte que as limas $\mathrm{K}$ de níquel-titânio. As limas flexíveis de aço inoxidável mostraram os melhores resultados. Os resultados mostraram que as limas flexíveis de aço inoxidável foram, quanto à capacidade de corte, claramente superiores às limas e alargadores de aço inoxidável e, principalmente, em relação às limas $\mathrm{K}$ de níquel-titânio.

Camps \& Perrot, 1995, promoveram um interessante trabalho para averiguar a influência das características geométricas (o desenho de suas secções transversais) na eficiência de desgaste comparando instrumentos de aço inoxidável (limas K e Flexofile da Maillefer), que serviram como controle, com instrumentos fabricados de níquel-titânio (limas K Brasseler, limas K JS Dental, limas K McSpadden e limas K Maillefer). Os instrumentos de aço inoxidável e secção transversal triangular foram mais eficientes que os instrumentos de aço inoxidável e secção transversal quadrangular. Diferenças significativas foram encontradas entre as limas $\mathrm{K}$ de níquel-titânio e destes as limas Maillefer foram as mais eficientes.

Usando como fator de variação a velocidade (Grupo A: 750rpm; Grupo B: 1300 rpm e Grupo C: $2000 \mathrm{rpm}$ ) no preparo de 36 canais mesiais de 18 molares inferiores, Poulsen et al., 1995, verificaram sua influência na forma do canal ao término do preparo. Os autores não verificaram diferenças estatisticamente significantes entre os três grupos experimentais quanto à quantidade de dentina removida, transporte do canal ou capacidade do instrumento em manter-se em posição cêntrica. 
Em 1995, Isom et al., empregando 52 canais mesiais de 26 molares inferiores, analisaram a espessura de dentina remanescente de canais curvos preparados com brocas Gates-Glidden \#2 e \#3 e Abridores de Canal M-Series \#30 a \#70 ou em movimentos lineares de entra-e-sai ou empregando o preparo anticurvatura. Para tanto constituíram quatro grupos experimentais e os resultados demonstraram que as brocas Gates-Glidden empregadas pelo método anticurvatura removeram estatisticamente quantidades significantemente maiores de dentina ao nível dos $2 \mathrm{~mm}$ da região de furca que qualquer outro método testado.

Glosson et al., 1995, compararam o desempenho de 5 diferentes instrumentos endodônticos - limas tipo K da Kerr (Kerr, Romulus, MI), limas manuais de níque-titânio (Mity File da J. S. Dental, Redgefield, CT), instrumentos rotatórios de níquel-titânio (lima NT Sensor da NT Co., Chattanooga, TN), limas manuais de níquel-titânio CMU (Canal Master U da Brasseler) e instrumentos rotatórios de níque-titânio Lightspeed (Lightspeed Technology Inc.) - no preparo de 60 canais radiculares de 30 molares inferiores com curvaturas entre $15^{\circ}$ e $31^{\circ}$. Os espécimes foram fotografados e incluídos em resina, seccionados, preparados e as imagens obtidas antes e após o preparo forma comparadas. Verificaram que os preparos com instrumentos rotatórios de níque-titânio (Lightspeed e NT Sensor) e com instrumentos manuais Canal Master "U" promoveram de forma significativa, estatisticamente, menos transporte do canal, atuaram de forma mais cêntrica, removeram menor quantidade de dentina e produziram formas circulares, relação ao preparo realizado com as limas K-Flex e Mity. 
Schäfer realizou em 1995 um estudo para a verificação das propriedades dos instrumentos manuais usados em movimentos de alargamento no preparo de canais radiculares curvos simulados em resina de polyester com $42^{\circ}$ graus de curvatura. Os canais foram instrumentados pela Técnica Seriada até o instrumento \#35 e, para tanto, empregou limas tipo K de níquel-titânio Mity, NiTi e Texceed; alargadores e limas K de aço inoxidável da Antaeos, Kerr e Maillefer; instrumentos flexíveis de aço inoxidável e ponta convencional Flexicut (Antaeos), Flexoreamer (Maillefer), K-Flex (Kerr) e K-Flexofile e instrumentos flexíveis de aço inoxidável e ponta não cortante Flexoreamer Batt tip (Maillefer), Flex-R (Union Broach) e K-Flexofile (Batt tip). Através de análise de fotografias obtidas antes e após o preparo dos canais verificou características indesejáveis quanto à forma final de preparo em todos os casos, com tendências ao desgaste da parede externa do canal na região ca curvatura e conseqüente de leve a severo alargamento localizado a este nível. Segundo o autor as melhores formas foram obtidas com instrumentos flexíveis e ponta não cortante.

Cheung et al., 1996a, não encontraram diferenças estatisticamente significantes, quanto à quantidade de dentina removida, quando da comparação in vitro dos preparos, de 24 canais de raízes mesiais de primeiros molares inferiores extraídos, obtidos com a instrumentação manual cérvico-apical com limas $\mathrm{K}$ de aço inoxidável e com a instrumentação com a peça de mão Excalibur. Os autores obtiveram perfurações radiculares em três espécimes do grupo preparado com a peça de mão Excalibur mas, no entanto, não as tiveram com o grupo de espécimes preparados manualmente. 
Chan \& Cheung, 1996b, compararam limas K de aço inoxidável e de níquel-titânio no preparo cérvico-apical no preparo de 24 canais radiculares de raízes mesiais moderadamente curvas de primeiros molares inferiores extraídos com vistas a determinarem e quantificarem os efeitos da instrumentação manual com tais instrumentos sobre a forma final do canal radicular. Para fins de análise o experimento compreendeu a aquisição de imagens de secções transversais, obtidas antes e após o preparo em três diferentes comprimentos da raiz, e que foram avaliadas quanto à quantidade de dentina removida, espessura das paredes mesial e distal remanescentes assim como a quantidade e direção do transporte dos canais. Os pesquisadores não encontraram diferenças estatisticamente significantes entre os dois grupos experimentais quanto à quantidade de dentina removida nos três diferentes níveis avaliados. Quanto ao transporte do canal observaram parecerem os instrumentos de níquel-titânio mais seguros.

Ao compararem limas $\mathrm{K}$ de aço inoxidável com instrumentos rotatórios de níquel-titânio em 1996, Tharuni et al. consideraram os últimos (Lightspeed) mais convenientes no preparo de canais radiculares curvos na medida em que promoveram baixa incidência de deformações (transporte e formação de zips e cotovelos) quando comparados aos instrumentos de aço.

Em 1996, Zmener et al. compararam os preparos de 45 canais simulados curvos em blocos de resina acrílica em função de três diferentes técnicas de preparo. No grupo experimental \#1, os 15 espécimes foram instrumentados com limas tipo K acopladas a uma aparelho ultra-sônico piezoelétrico, No grupo experimental \#2, os 15 espécimes foram 
instrumentados com instrumentos rotatórios ISO ProFile .04 Série 29 em peça de mão a baixa velocidade e alto torque. No grupo experimental \#3, o controle, os 15 espécimes foram instrumentados com limas tipo $\mathrm{K}$ em movimentos de limagem e tração do instrumento em viés. Os espécimes foram fotografados antes e após os preparos e os resultados foram submetidos à análise estatística que demonstrou que os instrumentos ProFile .04 Série 29 foram que os mais evidenciaram preparos cêntricos. No entanto, de forma controversa, os preparos produzidos pelos instrumentos dos grupos \#2 e \#3 (controle) resultaram em retificação da região curva assim como em transporte do forame apical em diferentes níveis do comprimento de trabalho.

Schäfer (1996) pesquisou o preparo de canais radiculares simulados em blocos de resina acrílica e $42^{\circ}$ de curvatura empregando quatro diferentes técnicas de preparo (SW (Senia \& Wildey, 1989), força balanceada, preparo escalonado e uma combinação de alargamento com força balanceada) com os instrumentos Flexoreamer Batt-tip (Maillefer, Ballaigues, Swistzerland), lima Flex-R (Union Broach, NY, USA) ou lima K-Flexofile (Maillefer, Ballaigues, Switzerland). A investigação foi realizada em condições padronizadas e empregando-se um programa de computador especialmente desenvolvido para fins de análise. Os resultados experimentais demonstraram diferenças estatisticamente significantes entre as quatro técnicas e os três instrumentos em todos os 14 pontos de mensuração. Os melhores resultados foram obtidos quando canais curvos foram inicialmente alargados com Flexoreamer Batt-tip ou limas Flex-R de \#15 a \#20 em movimentos de alargamento seguido do uso de instrumentos de \#25 a \#35 
com a técnica de força balanceada. De acordo com o autor esta combinação promoveu preparos satisfatórios sem degraus ou transporte.

Short et al., 1997, compararam as alterações de área e a capacidade de centralização e transporte do canal entre instrumentos rotatórios de níquel-titânio e limas manuais. Para tanto avaliaram os sistemas ProFile, Lightspeed, McXim e limas Flex-R aos níveis de 1, 3 e 5mm do comprimento de trabalho em molares incluídos em mufla para desmontagem e tomadas fotográficas digitais. Os resultados demonstraram que instrumentos de níquel-titânio tiveram com maior capacidade de manterem-se em posição cêntrica que os instrumentos de aço inoxidável.

Roig-Cayón et al. (1997) compararam 6 diferentes instrumentos endodônticos no preparo dos 240 canais de raízes mesiais de molares inferiores extraídos. Nos 40 espécimes do Grupo Experimental A o terço cervical do canal radicular foi preparado com brocas Gates-Glidden \#1 e \#2 e o preparo complementado com o emprego de limas Flexofile (Maillefer) pela técnica escalonada com limagem anticurvatura. No grupo experimental B os espécimes foram preparados com instrumentos rotatórios de níquel-titânio Canal Master pela Técnica Escalonada Cérvico-Apical. No grupo C os espécimes foram instrumentados com brocas Gates-Glidden e um antigo instrumento endodôntico, o HA (Micro-Mega, Beçanson, France) segmento cortante curto de $6 \mathrm{~mm}$. No grupo $\mathrm{D}$ os canais foram preparados com instrumentos de aço inoxidável Flexogate da Maillefer, limas K e brocas Gates-Glidden \#2 e \#3 empregando-se o preparo escalonado cérvico-apical e anticurvatura. No grupo $E$ os canais foram instrumentados com limas de 
níquel-titânio UF da Texceed e brocas Gates-Glidden \#2 e \#3. No grupo F os espécimes foram preparados com instrumentos rotatórios de níquel-titânio Lightspeed. Concluída a fase de preparo as raízes foram seccionadas transversalmente a 2, 5 e 9mm do ápice e avaliadas para a determinação da qualidade do preparo realizado segundo a forma, ou seja, circular, oval e irregular. Os melhores resultados foram obtidos com os instrumentos de níquel-titânio de arestas curtas e em movimentos de alargamento mais que em movimentos de limagem. Os instrumentos Canal Master U, a Flexogate e o Lightspeed promoveram significativamente mais formas circulares que a lima Flexofile e os instrumentos Heliapical e o Ultraflex em quaisquer dos níveis avaliados. O Lightspeed promoveu o maior número de formas circulares em quaisquer dos três níveis avaliados.

Em 1997, Schäfer ao promover uma revisão sobre os instrumentos endodônticos manuais para o preparo do canal radicular relata que os instrumentos de aço carbono foram usados até a década de sessenta quando da introdução dos instrumentos fabricados a partir de ligas de aço inoxidável. Segundo o autor as limas tipo $\mathrm{K}$ foram patenteadas pela Kerr Manufacturing Co. (Romulus, Michigan, USA) em 1915 e os instrumentos endodônticos para o preparo do canal radicular podem ser divididos, de acordo com a liga da qual são fabricados, em instrumentos de aço inoxidável, de níquel-titânio e de níquel-alumínio. Também relata que as principais mais recentes inovações foram o emprego de ligas de níquel-titânio na fabricação destes instrumentos, assim como a introdução de instrumentos com novas características geométricas como pontas modificadas e segmentos cortantes mais curtos. $\mathrm{O}$ 
autor conclui que os instrumentos flexíveis de aço inoxidável com pontas não cortantes, além de parecerem um avanço significativo na busca de um instrumento ideal, são superiores aos instrumentos de níquel-titânio tanto com relação à capacidade de corte como em relação ao preparo de canais curvos.

Thompson \& Dummer (1997a) - parte 1 - promoveram um estudo cujo objetivo era avaliar o preparo de 40 canais raidculares simulados em resina, confeccionados em quatro diferentes formas com relação à posição e ao ângulo de curvatura, com os instrumentos rotatórios de níquel-titânio ProFile .04 Taper Series 29 avaliando o tempo de preparo, fratura do instrumento, obstrução dos canais e perda de comprimento de trabalho assim como a análise tridimensional da forma alcançada com o preparo. Impressões dos canais após preparo demonstraram preparo apicais definidos, canais com paredes lisas e uma conicidade regular e contínua, criando um boa forma tridimensional. Dadas as condições experimentais os autores concluíram que os instrumentos ProFile .04 Taper Series 29 (Dentisply Maillefer) preparam os canais de forma rápida e com forma tridimensionalmente boa. Apesar da deformação de um número considerável de instrumentos não foi possível estabelecer se as estas ocorreram devido à natureza do modelo experimental ou a uma fragilidade intrínseca dos instrumentos avaliados.

Thompson \& Dummer (1997b) - parte 2 - averiguaram o preparo de canais radiculares simulados com o sistema de instrumentos rotatórios ProFile .04 Taper Series 29. Consideraram de particular importância o achado de que uma quantidade excessiva de resina foi removida na parede externa do canal radicular ao nível do ápice da curvatura, região freqüentemente 
associada à ocorrência de alargamento irregular e degraus. Segundo os autores esta observação contrasta com os padrões de remoção de dentina quando do emprego de instrumentos de aço inoxidável em que maior quantidade de resina é removida da parede interna do canal criando áreas ou zonas perigosas.

Thompson \& Dummer (1997c) - parte 1 - realizaram um estudo para a avaliação do preparo, escalonado ou o recomendado pelo fabricante, de 40 canais simulados com instrumentos rotatórios de níquel-titânio Lightspeed. Avaliaram tempo de preparo, fratura do instrumento, obstrução do canal, perda de comprimento de trabalho e forma tridimensional do preparo ao seu término. Segundo os autores os instrumentos Lightspeed prepararam os canais rapidamente, sem fraturas ou obstruções e perda mínima do comprimento de trabalho. No entanto, verificaram uma forma final de preparo comprometida provavelmente como resultado de um preparo escalonado ineficiente, o que implicaria na modificação da seqüência no preparo escalonado ou o emprego de instrumentos de maior conicidade para um melhor refinamento das paredes do canal antes de sua obturação.

Thompson \& Dummer (1997d) - parte 2 - avaliaram os preparos de 40 canais simulados, com diferentes ângulos e posição de curvatura, através da ação combinada dos instrumentos rotatórios NT e McXim, cada qual segundo as recomendações do fabricante. Neste experimento, a primeira parte de uma investigação do desempenho dos referidos instrumentos no preparo dos canais radiculares, os autores analisaram o tempo de trabalho, obstrução dos canais, fratura dos instrumentos, perda de comprimento de trabalho e forma 
tridimensional estabelecida ao término do preparo. Moldagens intracanal evidenciaram, tridimensionalmente, preparos cuja conicidade e fluxo foram considerados bons.

Pilo et al. (1998) verificaram a espessura da dentina remanescente em premolares inferiores preparados com instrumentos manuais e rotatórios. Os 12 espécimes foram incluídos em uma mufla, em resina, seccionados a 1, 3 e $5 \mathrm{~mm}$ apicalmente a partir do limite amelo-cementário, e instrumentados de forma escalonada ápico-cervical com limas $\mathrm{K}$ até o preparo apical com um instrumento \#40. Em seguida as muflas as secções foram desmontadas para as aferições devidas e, então remontadas, para o preparo da parte coronária (5mm) com brocas Gates-Glidden \#2 e \#4. A espessura da dentina residual em cada um dos doze espécimes, nas quatro direções de mensuração (vestibular, lingual, mesial e distal), nas diferentes secções e em função do instrumento empregado (lima K \#40 (controle), broca Gates-Glidden \#2 e brocas Gates-Glidden \#4) foram devidamente registrados. Os pesquisadores encontraram resultados estatisticamente significantes para as três variáveis (instrumento, secção e direção) assim como para a interação instrumento $x$ direção e secção x direção. Segundo os autores a redução da espessura de dentina por todos os procedimentos intracanal, principalmente com instrumentos rotatórios, pode ser um fator predisponente para subseqüente fratura vertical da raiz que é diretamente relacionada à quantidade de dentina removida. Aludem para que seu trabalho enfatiza a importância da preservação das paredes de dentina no sentido mesiodistal não comprometendo, portando, a integridade do dente. 
Thompson \& Dummer (1998a) - parte 1 - analisaram o preparo de 80 canais radiculares simulados com instrumentos rotatórios de níquel-titânio Mity Roto $360^{\circ}$ e Naviflex. Dadas as condições experimentais estabelecidas os pesquisadores verificaram que ambos os instrumentos preparam os canais rapidamente, sem fraturarem ou produzirem obstruções, e com perda mínima de comprimento de trabalho. No entanto, quanto à forma final de preparo concluem que tendo em vista características comprometedoras quanto à conicidade e ao fluxo, que a seqüência de preparo escalonado deva ser modificada e que, alternativamente deva se usar instrumentos de maior conicidade. Numa segunda etapa e neste mesmo ano (1998b) - parte 2 - os referidos autores estudaram os preparos de 40 canais radiculares simulados usando os mesmos instrumentos rotatórios de níquel-titânio - Mity Roto $360^{\circ}$ e Naviflex - avaliando a forma final de preparo quanto à deformações e transporte do canal radicular. Apesar de verificarem uma alta incidência de degraus, mas também a ausência de outras deformações do canal, os autores concluem serem os instrumentos um adicional valioso ao arsenal endodôntico.

Também em 1998, Thompson \& Dummer (1998c) - parte 1 investigaram os preparos de 40 canais radiculares simulados em resina acrílica com os instrumentos rotatórios de níquel-titânio Quantec Série 2000. O exame de moldagens dos canais radiculares preparados revelou que os instrumentos avaliados produziram canais com preparos apicais definidos, paredes lisas, com boas características de fluxo (afunilamento) e conicidade. Dessa forma os pesquisadores concluem que, das as condições de 
investigação estabelecidas, os instrumentos rotatórios de níquel-titânio Quantec Série 2000, prepararam os canais radiculares de forma rápida, segura e com forma tridimensional adequada.

Thompson \& Dummer (1998d) - parte 2 - investigaram os preparos de 40 canais radiculares simulados com instrumentos rotatórios de níquel-titânio Quantec Série 2000 e verificaram um número relativamente grande de deformações, quando do emprego de instrumentos de maior calibre ao nível do comprimento de trabalho, e 4 perfurações. Sob MEV os autores verificaram serem estes instrumentos dotados de uma ponta aguda que supõem poderiam predispor o transporte e a criação de deformações ao longo da parede externa principalmente nos canais radiculares severamente curvos.

Bryant et al. realizaram no ano de 1998 dois trabalhos para a investigação dos preparos de canais simulados em resina acrílica com instrumentos rotatórios de níquel-titânio do Sistema ProFile da Maillefer. Para o primeiro experimento (1998a) - parte 1 - produziram 40 canais simulados com diferentes ângulos e posição de curvaturas que foram preparados segundo a técnica cérvico-apical recomendada pelo fabricante. Avaliaram a eficiência dos instrumentos quanto ao tempo de preparo, fratura, ocorrência de obstrução, perda de comprimento de trabalho e forma tridimensional ao término do preparo. Impressões intracanais revelaram preparos apicais bem definidos, paredes lisas e fluxo e conicidade adequados. Dessa forma, os pesquisadores concluíram que o Sistema ProFile (Dentisply Maillefer, Switzerland) com pontas ISO prepararam os canais de forma rápida conferindo-Ihes formas tridimensionalmente adequadas. Numa segunda 
etapa - parte 2 - Bryant et al. (1998b) prepararam 40 canais simulados em resina acrílica, com diferentes ângulos e posição de curvatura, com os instrumentos anteriormente descritos (Sistema ProFile da Dentisply Maillefer, Switzerland) em uma abordagem cérvico-apical segundo recomendação do fabricante, para a avaliação das características de forma dos canais radiculares ao término do preparo. Não verificaram perfurações ou áreas de perigo mas uma diferença estatisticamente significante dos preparos quanto a formação de dilacerações e cotovelos. Os diâmetros variaram significativamente ao longo da extensão longitudinal dos canais com maiores diâmetros nos canais com $40^{\circ}$ de curvatura. Verificou-se uma tendência do instrumento em desgastar a parede externa nas regiões curvas do canal. Dessa forma os autores concluíram que os instrumentos rotatórios de níquel-titânio do Sistema ProFile com pontas ISO da Dentisply Mailllefer produziram uma quantidade de zips maior que a esperada mas, no entanto, dimensionalmente curtos e localizados.

Em sua Dissertação de Mestrado, em 1999, Miranzi promoveu a avaliação in vitro das alterações promovidas em canais radiculares artificiais curvos após a instrumentação com limas de níquel-titânio manuais (Onyx-R, Moyco Union Broach) e acionadas a motor (Pow-R, Moyco Union Broach), ambas auxiliadas por brocas Gates-Glidden \#1 e \#2 (Moyco Union Broach, e preparados pela Técnica Cérvico-Apical. Usando o programa de computador ImageTool, o pesquisador realizou a mensurações de área de imagens digitais dos espécimes obtidas antes e após o preparo. Os resultados demonstraram uma tendeência à formação de zips e danger zones(sic) 
(zonas perigosas) quando do preparo manual. O pesquisador concluiu que, comparativamente ao preparo dos canais radiculares com instrumentos rotatórios de níquel-titânio, no preparo manual promovem-se desgastes localizados de regiões específicas que, denotando transporte, resultam em deformações da configuração original dos mesmo.

Schäfer (1999a) - parte 1 - realizou um experimento para a verificação da relação entre as características geométricas (secção trasnversal e número de espiras) de instrumentos manuais especialmente confeccionados para o experimento e sua capacidade de corte. Dessa forma, comparou instrumentos com secções transversais quadrangular, triangular, romboidal (losangular), em forma de S e com o mesmo desenho de secção transversal de limas Hedströem. Adicionalmente tais instrumentos foram confeccionados com 16, 24 ou 32 espiras. Os instrumentos de secção romboidal e 24 espiras foram os que maiores desgastes promoveram independentemente da cinemática, limagem ou alargamento, empregada.

Schäfer (1999b) - parte 2 - realizou neste mesmo ano a análise do prepaor de canais radiculares retomando os instrumentos acima descritos. Verificou que os instrumentos de secção romboidal, de 16 ou 24 espiras promoveram os melhores preparos em termos de alargamento cêntrico e perda de comprimento de trabalho.

Ottosen et al., 1999, compararam preparos de canais radiculares com instrumentos rotatórios de níquel-titânio Naviflex e com o sistema ProFile. Para tanto, 40 raízes mesiais de molares humanos extraídos foram seccionadas, fotografadas e remontadas para preparo cérvico-apical. 
Concluída a fase de preparo os espécimes foram desmontados e novamente fotografados e superposição das imagens obtidas antes e após o preparo analisadas. Os autores não verificaram diferenças estatisticamente significante entre os recursos técnicos testados, assim como em relação ao grau de curvatura, quanto a preparo excêntrico ou quantidade de desgaste.

Bryant et al., 1999, realizaram uma análise do preparo de 40 canais simulados com instrumentos rotatórios de níquel-titânio ProFile .04 e .06 em uma abordagem cérvico-apical. Para fins de análise realizaram a superposição de imagens digitais obtidas antes e após o preparo. Os investigadores não tiveram fratura ou deformação dos instrumentos e nem tampouco canais obstruídos pela compactação de material ou degraus. A análise estatística dos dados experimentais demonstrou diferenças altamente significantes nos vários terços analisados quando ao desgaste. Também verificaram diferenças estatísticas altamente significantes quanto aos desgastes tanto da parede interna como da parede externa em função dos diferentes terços do canal radicular. Concluíram que a utilização dos instrumentos ProFile .04 e .06 torna o preparo do canal radicular rápido e efetivo produzindo boas formas exceto nos casos em que segmentos radiculares curvos e de pequena extensão têm a curvatura iniciando-se muito próxima do forame apical.

Em seu trabalho de revisão sobre as ligas de Níquel-Titânio, de 2000, Thompson relata que estas foram desenvolvidas no princípio da década de sessenta por W. F. Buehler (1963), um metalúrgico em busca de uma liga não magnética, resistente ao sal e à prova d'água para o programa espacial do 
Laboratório do Arsenal da Marinha Norte-Americana em Silver Springs no estado de Maryland (USA). As propriedades termodinâmicas desta liga intermetálica mostraram-se capazes de conferir à liga um efeito de memória de forma quando de um tratamento específico sob aquecimento controlado. A tal liga deram o nome de Nitinol, um acrônimo de Nickel-Titanium e Naval Ordnance Laboratory. Ainda segundo o autor a superelasticidade significa o retorno, uma vez removida a carga sobre o instrumento, à forma original antes que a deformação se estabeleça. Dessa forma instrumentos fabricados com esta liga metálica estariam indicados para o preparo dos canais radiculares curvos uma vez que em função da maior resistência e menor baixo módulo de elasticidade tais instrumentos não se deformariam permanentemente da maneira como o fazem os instrumentos fabricados em Aço Inoxidável.

Pesquisando sobre o preparo de canais radiculares simulados de resina, com diferentes ângulo e posição de curvatura, com os instrumentos rotatórios Hero (High Elasticity Rotary Instrumensts) 642 empregados numa técnica cérvico-apical, Thompson \& Dummer realizaram em 2000 uma investigação em que 40 espécimes foram fotografados antes e após os preparos e suas as imagens superpostas para uma análise iconográfica digital. Poucas deformações e nenhuma perfuração foram observadas. Segundo os autores, a relativa alta incidência de deformações verificada nos canais curtos e com ângulos agudos pode indicar que os instrumentos de maior diâmetro deveriam ser usados com precaução quando ao nível ou próximos da região apical. 
Schäfer et al., 2000, usaram MEV para a análise comparativa da eficiência de instrumentos manuais e rotatórios de níquel-titânio no preparo de canais radiculares. 120 dentes extraídos, 60 com raízes retas e 60 com pelo menos uma raiz curva, foram preparados manualmente de forma convencional com limas K-Flexofile, manualmente de forma escalonada com limas K-Flexofile, manualmente e de forma convencional com limas Hedströem, de forma automatizada com Endo-Flash da Kavo e de forma automatizada com ProFile da Maillefer-Dentsply. Verificaram-se graus equivalentes de limpeza quando da comparação do sistema Endo Flash da Kavo com o preparo manual. Não se verificou limpeza completa do canal radicular em qualquer dos preparos realizados. Os melhores preparos foram obtidos com o Sistema ProFile, principalmente nos canais curvos.

Kum et al, 2000, avaliaram a capacidade os preparos de canais radiculares de 36 blocos de resina empregando sistemas ProFile (ProFile .04/.06 e ProFile GT com ProFile .04) comparando-os com um grupo controle onde os canais foram instrumentados de forma escalonada cérvico-apical com limas K-Flexofile. Os espécimes foram fotografados antes e após os preparos, as imagens foram digitalizadas e superpostas foram analisadas em um aplicativo de imagem. Os instrumentos ProFile .04 promoveram desgastes significativamente menores que os outros instrumentos.

Rhodes et al., 2000, compararam os preparos de 30 canais de primeiros molares inferiores com limas manuais NiTiFlex, empregadas com a Técnica de Força Balanceada, e os instrumentos rotatórios ProFile 0.04 da Dentisply (Maillefer Dentisply, Switzerland), em uma abordagem 
cérvico-apical, usando análise tomográfica computadorizada do desgaste dentinário em níveis previamente estabelecidos. Os pesquisadores não constataram diferenças estatisticamente significantes entre os grupos experimentais para qualquer das variáveis testadas concluindo que ambas as formas de preparo produzem formas cêntricas e afuniladas.

Griffiths et al. avaliaram em 2000 os preparos de 40 canais simulados com os instrumentos rotatórios Quantec LX usando superposição de imagens seqüenciais obtidas antes e após os preparos dos canais radiculares assim como moldes concluídos os preparos para a avaliação tridimensional dos mesmos. Os resultados demonstraram uma tendência do Quantec LX em desgastar de forma excessiva a parede mesial do canal do iníco da curvatura em direção ao ápice radicular. Tal ocorrência tornou-se prevalentemente maior e mais severa quando do emprego de instrumentos de maior calibre ao nível da região apical. Dessa forma os autores atentam para que os instrumentos \#8, \#9 e \#10 devam ser usados com cuidado e não em grande profundidade, especialmente nos canais de raízes severamente curvas.

Machado (2000), realizou a avaliação in vitro do desgaste dentinário dos terços cervical e médio promovido pela ação de instrumentos rotatórios no preparo de canais radiculares. Realizou a comparação dos desgastes produzidos por brocas Gates-Glidden, brocas Largo-Peeso, Sistema ProFile ${ }^{\circledR}$ $.04 / .06 \&$ Orifice Shapers e Pow- ${ }^{T M} .04$ Taper File e Coronal Shapers avaliando em radiografias digitais obtidas antes e após o preparo dos canais a variação do diâmetro do canal radicular em cada um dos 10 espécimes de cada uma das 4 amostras. A análise dos dados experimentais permitiu 
verificar que o preparo com brocas Largo-Peeso promoveu um desgaste significantemente maior em relação aos grupos cujos espécimes foram prepardos com o Sistema ProFile ${ }^{\circledR} .04 / .06$ \& Orifice Shapers.

Szep et al., 2001, comparando instrumentos rotatórios de níquel-titâniocom instrumentos manuais de níquel-titânio e instrumentos manuais de ação inoxidável prepararam 80 canais simulados em resina com curvaturas de $36^{\circ}$ para a avaliação da eficiência e segurança do emprego dos mesmos. Os resultados mostraram os instrumentos manuais de aço inoxidável causando significantemente menor transporte em direção à parede interna do canal radicular que os instrumentos manais de níquel-titânio. Nos espécimes preparados com instrumentos rotatórios de níquel-titânio não foi possível evitar uma retificação do canal.

Griffiths et al, 2001, realizaram um experimento para a determinação da capacidade de modelagem dos instrumentos rotatórios Quantec SC em 40 canais simulados, através da superposição de imagens pré e pós-operatórias para verificação da quantidade de material removida. Segundo os pesquisadores, mediante as condições experimentais estabelecidas, os instrumentos rotatórios Quantec SC produziram aberrações significativas quando os canais foram preparados com instrumentos além do \#7 inclusive. Sugerem cuidado quando do preparo clínico do canal radicular com os referidos instrumentos.

Gluskin et al., 2001, através de reconstrução tomográfica computadorizada comparam os preparos cérvico-apicais de 50 espécimes produzidos por alunos de Odontologia usando instrumentos tradicionais na 
forma de brocas Gates-Glidden (Maillefer Dentistply Co.) em conjunção com limas Flexofile (Maillefer Dentistply Co.) ou os instrumentos rotatórios de níquel-titânio GT (Maillefer Dentistply Co.). Verificaram alterações de área, transporte do canal e espessura da estrutura radicular remanescente através da supersposição de imagens tomográficas. Concluíram que, dadas as condições experimentais, os estudantes foram capazes de preparar canais radiculares curvos com os instrumentos rotatórios GT com menor transporte e maior manutenção de estrutura com relação aos canais preparados com instrumentos manuais.

Fariniuk et al. (2001) afirmando que os conceitos relacionados ao preparo do canal radicular mudaram com o aparecimento dos instrumentos rotatórios de níquel-titânio preparam 24 canais simulados com curvaturas de $30^{\circ}$, divididos aleatoriamente em dois grupos experimentais, ou com ENDOflash ou com o Sistema ProFile ${ }^{\circledR} .04 / .06$ \& Orifice Shapers para verificação da capacidade modelagem dos mesmos. Os resultados apontaram diferenças significantes com o sistema ENDOflash promovendo o maior número de transportes do canal.

Fabra-Campos et al. (2001) verificaram a simetria dos preparos realizados com os instrumentos rotatórios Sistema Quantec 2000 em 20 raízes mésio-vestibulares de primeiros molares superiores e mesiais de primeiros molares inferiores. Os espécimes foram seccionados em quatro partes e imagens digitais obtidas antes e após os preparos foram analisadas para a verificação da relação do desgaste total em relação ao desgaste em cada uma das partes avaliadas. Observaram desgaste excêntrico, em direção 
à parede mesial do canal e em oposição á região de furca, quando da análise dos terços médio e apical. Concluíram que o sistema rotatório considerado é de fácil emprego e seguro, criando uma configuração tridimensional adequada.

Schäfer et al, 2001, comparam os preparos de canais simulados com Hero 642 e limas K-Flexofile de Aço Inoxidável. Os resultados experimentais mostraram que o Hero 642 produziu melhores preparos e menor quantidade de transporte do forame tanto nos canais com $28^{\circ}$ como nos canais com $35^{\circ}$ de curvatura. 


\section{PROPOSIÇÃO}

Este trabalho teve como propósito a análise morfométrica comparativa in vitro do desgaste dentinário produzido no preparo da região cervical de canais radiculares, de raízes mésio-vestibulares de primeiros molares superiores, com instrumentos rotatórios de Aço Inoxidável - (i) Brocas Gates-Glidden e (ii) Brocas Largo-Peeso - e rotatórios de Níquel-Titânio - (iii) Maillefer ProFile ${ }^{\circledR} .04 / .06$ \& Orifice Shapers e (iv) Pow-R ${ }^{\text {TM }}$ Coronal Shapers empregando-se como metodologia de pesquisa a análise de imagens radiográficas digitais obtidas antes e após o Preparo Químico-Cirúrgico para a avaliação das variações de área entre os espécimes dos quatro grupos experimentais.. 


\section{MATERIAL E MÉTODOS}

\subsection{Material}

Para a realização deste experimento empregou-se o seguinte material:

01. 40 dentes humanos permanentes molares superiores de adultos, extraídos, hígidos ou portadores de restaurações ou cáries que não comprometessem o assoalho da cavidade pulpar ou a entrada dos canais radiculares, com três raízes distintas e raízes mésio-vestibulares portadoras de canal principal único e que apresentassem ângulo de curvatura de aproximadamente $30^{\circ}$ (trinta graus);

02. 01 aparelho de raios $X$ convencional da marca Dabi-Atlante, mod. Spectroll;

03. 80 películas radiográficas periapicais Kodak Insight IP-21 (Eastman Kodak Company, Rochester-NY, USA);

04. 2 lâminas de cera utilidade da marca Wilsom (Polidental Indústria e Comércio Ltda.);

05. Revelador de filme radiográfico da marca Kodak (Eastman Kodak Company, Rochester-NY, USA); 
06. Fixador de filme radiográfico da marca Kodak (Eastman Kodak Company, Rochester-NY, USA);

07. Colgaduras para radiografias da marca FAVA (Metalúrgica FAVA Ind. e Com. - São Paulo-SP);

08. 01 câmara escura de acrílico para revelação de filmes radiográficos da marca CRIL-ART (CRIL-ART Ind. e Com. - São Paulo-SP);

09. 20 Cartelas de papelão para radiografias da marca ODONTO LONDON (ODONTO LONDON PRESS LTDA. - São Paulo-SP);

10. 01negatoscópio de Endodontia da marca $\vee \mathrm{H}$ ( $\vee \mathrm{H}$ Equip. Médicos e Odontológicos);

11. 01 lupa de aumento $4 \mathrm{X}$ BIO-ART (BIO-ART Equip. Odontológicos Ltda. - São Carlos-SP);

12. 01 lapiseira Pentel P209 de 0.9mm (Pentel JAPAN B32);

13. Papel vegetal da marca Gatway (Winsgs, USA);

14. 01régua plástica de $20 \mathrm{~cm}$ da marca BANDEIRANTE (Indústria BANDEIRANTE, Brasil);

15. 01 transferidor plástico de $180^{\circ}$ da marca BANDEIRANTE (Indústria BANDEIRANTE, Brasil);

16. Solução de Soro Fisiológico (Solução de Cloreto de Sódio 0,9\%, Fórmula \& Ação - Farmácia de Manipulação - São Paulo-SP);

17. 01 peça de mão de alta-rotação modelo Extra-torque da marca Kavo (Kavo do Brasil S/A, Blumenau-SC); 
18. 02 brocas de aço esféricas Carbide (Union Carbide) \#1, \#2 e \#3 para alta-rotação da marca;

19. 01 broca Endo-Z, para alta-rotação, da Maillefer (Maillefer, Ballaigues, Switzerland);

20. 01 caixa de limas tipo $\mathrm{K} \# 10$ da Maillefer (Maillefer, Ballaigues, Switzerland)

21. 01 caixa de limas tipo $\mathrm{K} \# 15$ da marca Maillefer (Maillefer, Ballaigues, Switzerland);

22. 01 régua endodôntica metálica de $35 \mathrm{~mm}$ da marca KERR (SYBRON KERR, Romulus-MI, USA) ;

23. 01 peça de mão reta para micro-motor da marca Dabi-Atlante (Dabi-Atlante, Ribeirão Preto-SP);

24. 01 mandril KG SORENSEN (KG SORENSEN, Barueri) para peça de mão reta ;

25. 02 discos de Carborundum Dentório;

26. 02 seringas descartáveis de $10 \mathrm{ml}$ cada uma da marca Plastipak (Becton \& Dickson Ind. Cir. Ltda., São Paulo-SP), uma para irrigação e outra carregada de Creme de Endo-PTC;

27. Creme de Endo-PTC da marca Fórmula \& Ação (Fórmula \& Ação Farmácia de Manipulação - São Paulo-SP);

28. 01 agulha metálica de calibre 40:06 (Ibrás, CBO Ind. Cirúrgica e Óptica S.A., Campinas-SP) para irrigação;

29. 01 intermediário metálico da marca FAVA (Metalúrgica FAVA Ltda, São Paulo-SP); 
30. 01 cânula metálica de calibre 40:20 (Ibras, CBO Ind. Cirúrgica e Óptica S.A., Campinas-SP) para aspiração;

31. Líquido de Dakin (Solução de Hipoclorito de Sódio 0,5\%) da marca Fórmula \& Ação (Fórmula \& Ação - Farmácia de Manipulação São Paulo-SP);

32. Iodofórmio da marca Fórmula \& Ação (Fórmula \& Ação - Farmácia de Manipulação - São Paulo-SP);

33. Polietilenoglicol 400 da marca Fórmula \& Ação (Fórmula \& Ação, Farmácia de Manipulação, São Paulo-SP);

34. 01 placa de vidro $A G$;

35. 01 espátula metálica da marca \# da marca DUFLEX (DUFLEX);

36. 01 seringa plástica de insulina descartável de 1cc da marca Becton \& Dickson (BD, Becton \& Dickson Ind. Cir. Ltda., Curitiba-PR);

37. 01 agulha metálica para insulina curta $30 \mathrm{G}$ de 5/16pol. da marca Ultra-Fine ${ }^{\circledR}$ II;

38. Pontas de papel absorvente de $1^{\text {a }}$ Série (\#15-\#40) DENTSPLY (DENTSPLY Ind. e Com. Ltda, Petrópolis) ;

39. 01 calcador endodôntico metálico \#10 KERR (SYBRON KERR, Romulus-MI, USA);

40. 01 cureta metálica \#18 DUFLEX (SS WHITE, Rio de Janeiro);

41. 01 pinça clínica da \#318 DUFLEX (SS WHITE, Rio de Janeiro);

42. Algodão da marca CREMER;

43. Gaze;

44. 01 caneta na cor azul da marca Bic; 
45. 40 molduras para diapositivo da marca Diamount (Diamount Ind. Bras. São Paulo-SP, Brasil);

46. 40 lâminas de chumbo de películas radiográficas periapicais da marca Kodak;

47. 01 aparelho de raios $X$ digital da marca Trophy (Trophy - Paris, France) mod. CCX Elitys;

48. 04 discos flexíveis de 3,5 pol. da marca Maxwell;

49. 01 motor elétrico da marca VK DRILLER (VK DRILLER Equipamentos Elétricos Ltda., São Paulo-SP), mod. ENDO Plus (comprimento $=18,7 \mathrm{~cm}$, profundidade $=18,0 \mathrm{~cm}$, altura $=10,5 \mathrm{~cm}$, peso $=2,52 \mathrm{~kg}, 110 / 220 \mathrm{v}-220 / 240 \mathrm{v}$, indicado pelo fabricante para procedimentos endodônticos de instrumentação do conduto radicular com instrumentos rotatórios de Níquel-Titânio. Constitui-se de uma unidade de CPU (Central Processor Unit), um micromotor, um pedal e um suporte de silicone para o micromotor. O aparelho permite o ajuste dos seguintes parâmetros: velocidade medida em rpm, redução de velocidade (1:1, 16:1, 18:1, 20:1, 64:1, 120:1 e 1000:1), torque $(1,2,3,4,5,6,7,8,9,10,12,14,16,18$ e 20 N.cm);

50. Brocas Gates-Glidden de aço inoxidável \#1, \#2 e \#3 da Maillefer (Dentsply Maillefer, Ballaigues, Switzerland);

51. Brocas Largo-Peeso de aço inoxidável \#1, \#2 e \#3 da Maillefer (Dentsply Maillefer, Ballaigues, Switzerland); 
52. ProFile ${ }^{\circledR} .04 / .06$ \& Orifice Shaper ${ }^{\mathrm{TM}}$ (Dentsply Maillefer, Ballaigues, Switzerland) - sistema de preparo do canal radicular com instrumentos endodônticos rotatórios de Níquel-Titânio ISO combinando-se limas ProFile ${ }^{\circledR} .04 / 20, .04 / 25, .06 / 20$ e $.06 / 25$ e Orifice Openers (abridores de orifício) ProFile ${ }^{\circledR}$ OS (Orifice Shaper $\left.{ }^{\mathrm{TM}}\right)$, modeladores de orifício, \#2 (.06/30) e \#3 (.06;/40), todos com $21 \mathrm{~mm}$ de comprimento;

53. Instrumentos endodônticos rotatórios de Níquel-Titânio para o preparo do canal radicular Pow-R ${ }^{\mathrm{TM}}$ Coronal Shapers (Moyco Union Broach - York(PA), USA) nos seguintes tapers (conicidades): .08/60 (azul), .08/45 (branco), .06/35 (verde) e $.06 / 25$ (vermelho), todos de $18 \mathrm{~mm}$;

54. 01 computador composto de um monitor SVGA de 14pol. AcerView 35cL (Acer) e de uma CPU com processador AMD K-6II de 550mHz, Disco Rígido de 10Gyga-bytes e 64Mega-bytes de RAM;

55. Programa de computador de análise gráfica ImageLab 2000 do LIDO (Laboratório de Informática Dedicado à Odontologia da Faculdade de Odontologia da Universidade de São Paulo-São Paulo), desenvolvido por Ricardo Carneiro Borra, destinado a análises morfométricas e subtração de imagens tanto de espécimes macroscópicos como microscópicos;

56. Programa de computador para análise estatística GMC versão 8.1, editado em 01/03/2003, desenvolvido pelo Prof. Dr. Geraldo Maia 
Campos da Faculdade de Odontologia de Ribeirão Preto da Universidade de São Paulo-Ribeirão Preto;

\subsection{Métodos}

40 dentes humanos permanentes de adultos primeiros molares superiores extraídos por razões desconhecidas, fornecidos pelo Banco de Dentes da Disciplina de Endodontia do Departamento de Dentística da Faculdade de Odontologia da Universidade de São Paulo, foram usados para compor as amostras deste experimento. Na seleção inicial dos espécimes adotou-se como critério que seus constituintes fossem dentes hígidos ou portadores de restaurações ou cáries que não comprometessem o assoalho da câmara pulpar ou a entrada dos canais radiculares e que possuíssem de forma distinta três raízes.

Os espécimes foram radiografados com um aparelho de raios $X$ convencional Spectroll da Dabi-Atlante, calibrado para 0,4s. de exposição, e películas periapicais da marca Kodak. As tomadas radiográficas foram realizadas empregando-se a Técnica de Paralelismo nos sentidos orto-radial e mésio-radial com os dentes afixados às películas com cera utilidade. As imagens radiográficas foram avaliadas com lupa em um negatoscópio, para a confirmação da presença de um canal principal único nas raízes mésio-vestibulares. Então procedeu-se à confirmação dos ângulos de 
curvatura das raízes de acordo com a Técnica concebida por Schneider em 1971, selecionando-se apenas raízes cujo ângulo fosse de aproximadamente $30^{\circ}$.

Subseqüentemente e para fins de hidratação os espécimes foram armazenados em soro fisiológico (solução de Cloreto de Sódio 0,9\%) por 72h.

Então procedeu-se à cirurgia de acesso em todos os 40 espécimes, segundo a técnica preconizada por Paiva \& Antoniazzi, 1982, empregando-se brocas esféricas Carbide e broca Endo-Z.

A seguir a raiz palatina de cada espécime foi removida com um disco de Carborundum montado em mandril acionado em baixa rotação por peça de mão reta em micromotor.

Após a Penetração Desinfetante, segundo Paiva \& Antoniazzi (1982), as raízes foram imersas em Líquido de Dakin (solução de Hipoclorito de Sódio 0,5\%) por $15 \mathrm{~min}$. e então lavadas em água corrente.

Para fins de contraste radiográfico e empregando-se uma seringa de insulina, depois de secos, todos os canais radiculares foram preenchidos com pasta confeccionada de lodofórmio e Polietilenoglicol 400 na proporção de 4:1. Adicionalmente, com uma cureta de dentina, levou-se pó de lodofórmio à entrada dos canais radiculares e este foi condensado com um calcador endodôntico buscando-se o preenchimento de toda a extensão dos mesmos.

Então, os dentes foram enumerados compondo-se 4 diferentes grupos experimentais, cada qual constituído de 10 espécimes:

(i) Grupo Experimental \#1 - G1 - composto dos dentes-espécimes de \#01 a \#10; 
(ii) (ii) Grupo Experimental \#2 - G2 - composto dos dentes-espécimes de \#11 a \#20;

(iii) (iii) Grupo Experimental \#3 - G3 - composto dos dentes-espécimes de \#21 a \#30 e

(iv) (iv) Grupo Experimental \#4 - G4 - composto dos dentes-espécimes de \#31 a \#40.

Para as tomadas radiográficas digitais, antes e após o Preparo Químico-Cirúrgico, criou-se um dispositivo - limitador de área radiográfica conforme Machado (2001) - para fins de padronização da dimensão radicular longitudinal a ser radiografada em $4 \mathrm{~mm}$, considerando-se $11,7 \mathrm{~mm}$ (Paiva \& Antoniazzi, 1988) como valor referencial de comprimento para as raízes mésio-vestibulares de primeiros molares superiores. Os 40 limitadores, um para cada espécime, foram confeccionados com molduras para diapositivos acopladas de lâminas de chumbo de invólucros de filmes radiográficos convencionais da marca Kodak, preservando-se as larguras originais das janelas dos diapositivos. Ainda para fins de padronização da região radicular a ser radiografada realizaram-se demarcações tanto no dente como nos limitadores de tal forma que um vez justapostos, limitador e espécime, se tivesse a coincidência dessas marcas em cada tomada radiográfica de um espécime antes e após o preparo do canal.

Assim, procedeu-se à realização das tomadas radiográficas digitais empregando-se um sistema radiovisiográfico (RVG) com um aparelho de raios X digital da marca Trophy (Trophy, Paris, France), mod. CCX Elitys, As tomadas radiográficas foram realizadas pela Técnica do Paralelismo no 
sentido orto-radial usando-se uma distância focal de $20 \mathrm{~cm}$ e tempo de exposição de 0,12mAs.

Após a captura da imagem e sua elaboração gráfica (geração de imagem do espécime irradiado), e constatada a sua viabilidade vista a proposta experimental, as imagens eram armazenadas (salvas) em disco flexível de 3,5pol. e devidamente catalogadas para a posterior avaliação iconográfica de caráter morfométrico.

Concluída esta primeira etapa experimental, após a primeira aquisição de imagens, procedeu-se ao Preparo Químico-Cirúrgico dos canais radiculares empregando-se 4 diferentes métodos:

(i) no Grupo Experimental \#1, o G1, empregou-se no preparo dos canais radiculares a Técnica Cérvico-Apical advogada por Machado (1993): (i) a princípio os canais foram explorados com lima tipo $\mathrm{K} \# 15$ até $4 \mathrm{~mm}$ aquém do comprimento médio da raiz; (ii) em seguida, preparo da região cervical do canal radicular com broca Gates-Glidden \#1, montada em contra-ângulo e acionada em baixa velocidade, em movimentos de vai-e-vem e ligeira pressão tanto apical como em direção à parede externa do canal; (iii) livre e não cortante o instrumento anterior era substituído por uma broca Gates-Glidden \#2 empregada da forma anteriormente descrita; (iv) preparo até o terço médio com broca Gates-Glidden \#1 da forma descrita no item 1. Proporcionalmente, em função da variação anatômica, canais de maior diâmetro foram instrumentados com seqüência de brocas de maior diâmetro. Durante toda a fase de preparo os canais radiculares estiveram preenchidos com Creme de Endo-PTC ativado por Líquido de Dakin (solução de Hipoclorito de Sódio 
$0.5 \%$ ), renovados entre os instrumentos, e foram abundantemente irrigados com Líquido de Dakin.

(ii) no Grupo Experimental \#2, o G2, os canais radiculares foram preparados com brocas Largo-Peeso \#1 e \#2 pela Técnica Cérvico-Apical, conforme Machado (1993) e regime de irrigação, conforme descritos para o G1.

(iii) no Grupo Experimental \#3, o G3, os canais radiculares foram instrumentados empregando-se um sistema de preparo comercialmente disponível - ProFile $^{\circledR} .04 / .06$ \& Orifice Shapers ${ }^{\mathrm{TM}}$ (Dentsply Maillefer, Ballaigues, Switzerland) - compreendido por instrumentos rotatórios (limas e abridores de orifício, respectivamente) de Níquel-Titânio para serem empregados em uma seqüência Crown-Down (Cérvico-Apical) sugerida pelo fabricante. e que segundo esse pode ser modificada em situações clínicas particulares. Preconiza-se, ainda, o uso destes instrumentos em rotação a uma velocidade estável entre 150 e 350rpm com movimentos leves e contínuos de entra-e-sai(sic), instrumentação passiva sem forçar o instrumento em direção apical (quando o avanço tornar-se difícil usar o subseqüente) e em um tempo de trabalho que não exceda 5-10s. Destarte prescrição do fabricante para o uso deste grupo de instrumentos na realização de todo o Preparo Químico-Cirúrgico do canal radicular, neste experimento empregou-se apenas o conjunto de instrumentos destinados ao preparo da porção coronária(sic) do canal radicular e na seqüência cérvico-apical sugerida. Dessa forma o preparo foi realizado da seguinte forma: (i) preparo inicial com Orifice Openers (abridores de orifício) ProFile ${ }^{\circledR}$ OS (Orifice 
Shapers $^{\mathrm{TM}}$ - modeladores de orifício) \#3 (.06/40) e \#2 (.06/30) e, subseqüentemente, (ii) preparo seqüencial em direção à região apical do canal radicular com limas ProFile ${ }^{\circledR} .06 / 25, .06 / 20$ e $.04 / 25$. Durante toda a fase de preparo os canais radiculares estiveram preenchidos com Creme de Endo-PTC ativado por solução de Hipoclorito de Sódio $0.5 \%$, renovados entre os instrumentos, e foram abundantemente irrigados com solução de Hipoclorito de Sódio 0.5\%.

(iv) no Grupo Experimental \#4, o G4, os canais foram preparados pela Técnica Cérvico-Apical com instrumentos de Níquel-Titânio Pow-R ${ }^{\text {TM }} .04$ Taper File \& Coronal Shapers (Moyco Union Broach, York-PA, USA) que, segundo o fabricante, podem substituir brocas Gates-Glidden e assim diminuir-se o risco de formação de degrau e de fratura do instrumento. Estes instrumentos de ponta não cortante R (os instrumentos do Sistema Pow-R de preparo do canal radicular são dostados da ponta arredondada não cortante patenteada por Roane em 1985) foram usados em velocidade de rotação contínua, 150 a 350rpm, no sentido horário e com torque controlado. Após a exploração do canal com lima tipo K \#10 empregou-se os da seguinte maneira: (i) Pow-R ${ }^{\mathrm{TM}}-\mathrm{CS} .08 / 60$ - 18mm; (ii) Pow-R - CS - .08/45 - 18mm; (iii) Pow-R $\mathrm{R}^{\mathrm{TM}}-.06 / 35$ - 18mm; (iv) Pow-R ${ }^{\mathrm{TM}}-\mathrm{CS}-.06 / 25$ - 18mm; (v) exploração do canal com lima tipo K \#10; (vi) Pow-R ${ }^{\mathrm{TM}}$ Taper File .04/45 $21 \mathrm{~mm}$ no terço médio do canal radicular. Todos os instrumentos foram usados em tempo que não excedesse 4 s ou até que se sentisse resistência conforme instruções do fabricante. 
Tabela A - Seqüência de instrumentos empregados no experimento em cada grupo experimental

\begin{tabular}{|c|c|c|c|c|c|}
\hline \multirow[t]{2}{*}{ Instrumento } & \multicolumn{5}{|c|}{ Seqüência } \\
\hline & 1 & 2 & 3 & 4 & 5 \\
\hline $\begin{array}{c}\text { Broca } \\
\text { Gates-Glidden }\end{array}$ & $\mathrm{K} \# 15$ & G \#1 & G \#2 & G \#1 & \\
\hline $\begin{array}{c}\text { Broca } \\
\text { Largo-Peeso }\end{array}$ & $\mathrm{K} \# 15$ & L \#1 & L \#2 & L \#1 & \\
\hline $\begin{array}{c}\text { ProFile }^{\circledR} .04 / .06 \& \\
\text { Orifice Shapers* }^{*}\end{array}$ & OS3 - .06/40 & OS2 - .06/30 & $.06 / 25$ & $.06 / 20$ & $.04 / 25$ \\
\hline $\begin{array}{l}\text { Sistema Pow-R }{ }^{\mathrm{TM}} \\
-.04 \text { Taper File e } \\
\text { Coronal Shapers* }\end{array}$ & CS .08/60 & CS .08/45 & CS .06/35 & CS .06/25 & $.04 / 25$ \\
\hline
\end{tabular}

* seqüência destinada ao preparo da região cervical do canal radicular segundo o fabricante

Nos G3 e G4 o preparo atendeu os seguintes critérios básicos:

(i) movimentação suave do instrumento em vai-e-vem;

(ii) rotação no sentido horário, contínua e estável, a uma velocidade entre 150 e 350rpm;

(iii) mínima pressão do instrumento em direção à região apical do canal radicular;

(iv) análise macroscópica do instrumento para verificação de possíveis alterações da forma original do instrumento;

(v) irrigação-aspiração com substâncias químicas auxiliares durante todo o preparo. 
Em todos os grupos experimentais os instrumentos foram acionados pelo motor elétrico ENDO Plus da VK DRILLER e todos os espécimes foram preparados na mão e por um único operador.

Concluída a fase de preparo, os canais radiculares de todos os espécimes foram novamente preenchidos com lodofórmio e radiografados com o aparelho de raios $\mathrm{X}$ digital anteriormente referido e as imagens adquiridas armazenadas em disco flexível de 3,5pol. Todas as imagens radiovisiográficas foram geradas no formato TIF (Tagged Image File).

A fase seguinte consistiu na análise iconográfica para as mensurações das áreas das paredes (mesial e distal) dos canais radiculares e suas respectivas variações em cada um dos 40 espécimes, perfazendo 80 imagens, através do programa de computador ImageLab desenvolvido por Ricardo Carneiro Borra (2000) e instalado em computador do LIDO (Laboratório de Informática dedicado à Odontologia) da Faculdade de Odontologia da Universidade de São Paulo..

Do ponto de vista operacional as imagens foram analisadas em seu formato TIF original e o processo, acionando-se os ícones das barras de ferramentas do programa, consistiu em:

(i) visualização da imagem na proporção 1:2;

(ii) disposição de janelas lado a lado verticalmente (para a aferição das medidas de área de um mesmo espécime, antes do preparo e após o preparo, simultaneamente);

(iii) seleção através da delimitação da região iconográfica ou estrutura (conforme nomenclatura empregada pelo programa); 
(iv) cálculo das áreas respectivas e anotação dos valores respectivos.

Dessa forma os dados amostrais compreenderam valores de área, através da aferição do número de pixels (picture elements) da região selecionada, para cada uma das paredes mesiais e paredes distais de cada uma das imagens antes e após o preparo do espécime analisado.

Obtidos os valores das referidas mensurações, os dados amostrais originais foram devidamente tabulados de tal forma a obter-se valores absolutos em número de pixels $\times 10^{2}$. e esses, por sua vez, em valores relativos em porcentagem tanto para cada uma das seções (paredes mesial e distal), isoladamente como para a área radicular total através do produto da soma desses valores.

Em seguida, após o cálculo das variações de área para cada espécime, por razões de ordem metodológica, usou-se dos dados experimentais relativos em percentuais de pixels para a realização da avaliação estatística. Esta última, por sua vez, foi realizada com o programa para computador e destinado à pesquisa biológica GMC versão 8.1 de autoria do Prof. Dr. Geraldo Maia Campos.

A análise estatística compreendeu o cálculo de medidas de tendência central (Média Aritmética) e de dispersão (Variância e Desvio Padrão), Testes de Normalidade (Parâmetros Amostrais, Distribuição de Freqüências, Histograma da distribuição amostral, Teste de Aderência à curva normal e Teste de Homgeneidade Cochran), Testes Paramétricos Não-Gráficos para comparações múltiplas de fatores independentes, cada um com número igual 
de repetições, ou seja, o ANOVA (Análise de Variância) em função da distribuição normal dos dados amostrais. Subseqüentemente realizaram-se os Testes Auxiliares de Bartlett e de Tukey.

Os dados amostrais originais em valores absolutos em pixels e seus respectivos valores relativos calculados em percentuais, os valores originais absolutos em pixels referentes às variações de área devidamente calculados e seus valores relativos em percentuais respectivos, os resultados dos testes de normalidade e os resultados dos testes estatísticos devidamente tabulados encontram-se compilados como os Anexos A, B e C neste trabalho. 


\section{RESULTADOS}

Neste experimento, os dados amostrais foram originalmente obtidos da mensuração das áreas das paredes mesial e distal de imagens radiográficas digitais de cada um dos espécimes, raízes mesiovestibulares de primeiros molares superiores, adquiridas antes e após o Preparo Químico-Cirúrgico. Os resultados dos cálculos das áreas realizados pelo programa de computador ImageLab eram fornecidos em quantidades de pixels (picture elements) das regiões iconográficas selecionadas - parede mesial e parede distal.

Os dados amostrais expressos em valores absolutos $\times 10^{2}$ em pixels de cada uma das paredes, a área total (o produto da soma dos valores de área das paredes mesial e distal de cada espécime), os valores obtidos da conversão dos valores absolutos em valores relativos na forma de porcentagem assim como os valores das variações de área de cada parede e da estrutura total em cada espécime foram devidamente tabulados. Dessa forma, a análise foi realizada comparando-se os valores relativos das variações de área em cada espécime dos vários grupos experimentais.

A análise inicial dos dados experimentais permitiu as seguintes observações de ordem geral: 
01) Em todos os espécimes de todos os grupos experimentais verificou-se a diminuição tanto das áreas das paredes mesiais como das paredes distais.

02) Em todos os espécimes de todos os grupos experimentais verificou-se a diminuição das áreas de estrutura radicular total (produto da soma das paredes de cada espécime) analisadas.

Ainda, avaliação precípua dos resultados permitiu as seguintes observações de ordem geral em cada amostra:

01)Grupo Experimental \#1 - Preparo com brocas Gates-Glidden:

- em $80 \%$ dos espécimes a parede distal foi a que maior desgaste sofreu;

- em $20 \%$ dos espécimes a parede mesial foi a que maior desgaste sofreu;

- o maior desgaste de estrutura total foi $23,19 \%$ e o menor $6,60 \%$;

- os maiores desgastes seccionais foram $23,54 \%$ para as parede mesiais e $35,78 \%$ para as distais;

- os menores desgastes seccionais foram 2,99\% para as paredes mesiais e $7,04 \%$ para as distais;

- a maior diferença de desgaste entre paredes de um mesmo espécime foi $90,26 \%$ de uma parede distal em relação a sua complementar mesial;

- a menor diferença de desgaste entre paredes de um mesmo espécime foi $1,67 \%$ de uma parede distal em relação a sua complementar mesial. 
02) Grupo Experimental \#2 - Preparo com brocas Largo-Peeso:

- em $90 \%$ dos espécimes a parede distal foi a que maior desgaste sofreu;

- em $10 \%$ dos espécimes a parede mesial foi a que maior desgaste sofreu;

- o maior desgaste de estrutura total foi $17,80 \%$ e o menor $4,80 \%$;

- os maiores desgastes seccionais foram $16,37 \%$ para as paredes mesiais e $25,60 \%$ para as distais;

- os menores desgastes seccionais foram $3,95 \%$ para as paredes mesiais e $1,47 \%$ para as paredes distais;

- a maior diferença de desgaste entre paredes de um mesmo espécime foi $83,34 \%$ de uma parede distal em relação a sua complementar mesial;

- a menor diferença de desgaste entre paredes de um mesmo espécime foi $12,37 \%$ de uma parede distal em relação a sua complementar mesial.

03) Grupo Experimental \#3 - Preparo com Profile ${ }^{\circledR} .04$ e .06 \& Orifice Shapers:

- em $50 \%$ dos espécimes a parede distal foi a que maior desgaste sofreu;

- em $50 \%$ dos espécimes a parede mesial foi a que maior desgaste sofreu;

- o maior desgaste de estrutura total foi $20,82 \%$ e a menor $2,72 \%$; 
- os maiores desgastes seccionais foram $14,35 \%$ para as paredes mesiais e $28,37 \%$ para as distais;

- os menores desgastes seccionais foram $1,42 \%$ para as paredes mesiais e $2,14 \%$ para as distais;

- a maior diferença de desgaste entre paredes de um mesmo espécime foi $80,72 \%$ de uma parede distal em relação a sua complementar mesial;

- a menor diferença de desgaste entre paredes de um mesmo espécime foi $11,81 \%$ de uma parede distal em relação a sua complementar mesial.

04) Grupo Experimental \#4 - Preparo com Pow- $R^{\mathrm{TM}}$ Coronal Shapers:

- em $80 \%$ dos espécimes a parede distal foi a que maior desgaste sofreu;

- em $20 \%$ dos espécimes a parede mesial foi a que maior desgaste sofreu;

- o maior desgaste de estrutura global foi $25,30 \%$ e o menor $8,03 \%$;

- os maiores desgastes seccionais foram $20,28 \%$ para as paredes mesiais e $32,92 \%$ para as distais;

- os menores desgastes seccionais foram $1,88 \%$ para as paredes mesiais e $7,51 \%$ para as distais;

- a maior diferença de desgaste entre paredes de um mesmo espécime foi $79,11 \%$ de uma parede distal em relação a sua complementar mesial; 
- a menor diferença de desgaste entre paredes de um mesmo espécime foi $1,12 \%$ de uma parede distal em relação a sua complementar mesial. A análise estatística compreendeu a comparação dos valores relativos das variações de área seccional (parede mesial e parede distal) e total (produto da soma das variações seccionais). Assim os testes estatísticos foram realizados tendo-se área como variável e paredes como fatores múltiplos e independentes de variação para um igual número de repetições.

As tabelas referentes aos dados experimentais bem como a sua avaliação estatística - testes de normalidade, testes estatísticos e gráficos das amostras constam como Anexos deste trabalho da seguinte forma:

Dados Amostrais:

As Tabelas An.A1 a An.A4 apresentam os valores originais em pixels, divididos por $10^{2}$, das áreas dos espécimes para cada grupo experimental antes e após o Preparo Químico-Cirúrgico dos canais radiculares com os vários recursos testados.

As Tabelas An.5 a An.A8 apresentam os valores das variações de área dos espécimes dos grupos experimentais após o Preparo Químico-Cirúrgico dos canais radiculares com os vários recursos testados.

Avaliação estatística - testes de normalidade:

As Tabelas An.B9 a An.B11 apresentam os Testes de Normalidade (Parâmetros Amostrais, Distribuição de Freqüências e Teste de Aderência à Curva Normal) para valores de variação de área considerando-se o fator de variação parede mesial em cada grupo experimental. 
As Tabelas An.B12 a An.B14 apresentam os Testes de Normalidade (Parâmetros Amostrais, Distribuição de Freqüências e Teste de Aderência à Curva Normal) para os valores de variação de área considerando-se o fator de variação parede distal em cada grupo experimental.

As Tabelas An.B15 a An.B17 apresentam os Testes de Normalidade (Parâmetros Amostrais, Distribuição de Freqüências e Teste de Aderência à Curva Normal) para os valores de variação de área considerando-se o fator de variação paredes mesial e distal em cada grupo experimental.

Parâmetros Amostrais:

A Tabela An.C18 apresenta os parâmetros amostrais segundo a amostra e o fator de variação analisado com valores expressos em porcentagem.

A Tabela An.C19 apresenta os Parâmetros Amostrais dos quatro grupos experimentais segundo o fator de variação, ou seja, a parede analisada.

Testes estatísticos:

a) Teste de Bartlett: a Tabela An.C20 apresenta o Teste de Homogeneidade de Bartlett para os valores das variações de área segundo cada fator de variação experimental.

b) Análise de Variância: as Tabelas An.C21 a An.C23 apresentam a Análise de Variância - $\alpha=5 \%$ - para as quatro amostras segundo o fator de variação.

c) Teste de Tukey: a Tabela An.C25 apresenta o Teste de Tukey - $\alpha=$ $5 \%$ - para as quatro amostras segundo o fator de variação. Nas 
Tabelas An.C27 a An.C29 estão os resultados das comparações das médias dos grupos experimentais em função de cada fator de variação considerando-se o Valor Crítico de Tukey (Diferença Mínima Significante) calculado para $\alpha=5 \%$

Gráficos:

O Gráfico An.B1 ilustra as variações de área das paredes mesiais nos quatro grupos experimentais.

O Gráfico An.B2 ilustra as variações de área das paredes distais nos quatro grupos experimentais.

O Gráfico An.B3 ilustra as variações de área das paredes mesiais e distais nos quatro grupos experimentais.

O Gráfico An.B4 demonstra a quantidade em percentual de paredes mesial e distal mais desgastadas em cada grupo experimental..

O Gráfico Ana.C5 ilustra as médias de desgaste segundo o fator de variação para cada grupo experimental.

Resultados da avaliação estatística dos dados experimentais:

01) os testes de normalidade para cada fator de variação - parede mesial, parede distal e paredes mesial e distal - demonstraram que a distribuição dos dados amostrais era normal (Tabelas An.B9 a An.B17), o que permitiu a aplicação de testes estatísticos paramétricos;

02) O Teste de Bartlett para cada um dos fatores de variação demonstrou tratam-se de amostras iguais, extraídas de uma 
mesma população, com variâncias homogêneas tratando-se de amostras homoscedásticas (Tabela An.C20);

03) a análise de variância do fator parede mesial para $\alpha=5 \%$ demonstrou não haver diferenças estatisticamente significantes entre as médias das quatro amostras (Tabelas An.C21): $\mathrm{P}\left(\mathrm{H}_{0}\right)=24,15 \%$ (menor probabilidade de $\mathrm{H}_{1}$ ) e $\mathrm{F}=1,47$ para 2,62 (segundo Tabela de valores de $F$ para $\alpha=5 \%, 4$ graus de liberdade no numerador e 36 graus de liberdade no denominador - valor de interpolação);

04) a análise de variância do fator parede distal para $\alpha=5 \%$ demonstrou haver diferenças estatisticamente significantes entre as médias das quatro amostras (Tabelas An.C22): $P\left(H_{0}\right)=4,68 \%$ (maior probabilidade de $\mathrm{H}_{1}$ ) e $\mathrm{F}=2,91$ contra 2,62 (conforme Tabela de valores de $F$ para $\alpha=5 \%, 4$ graus de liberdade no numerador (amostras) e 36 graus de liberdade no denominador valor de interpolação);

05) a análise de variância do fator paredes mesial e distal para $\alpha=5 \%$ demonstrou haver diferenças estatisticamente significantes entre as médias das quatro amostras (Tabelas An.C23): $P\left(H_{0}\right)=4.06 \%$ (maior probabilidade de $\mathrm{H}_{1}$ ) e $\mathrm{F}=3,04$ contra 2,62 (conforme Tabela de valores de $F$ para $\alpha=5 \%, 4$ graus de liberdade no numerador (amostras) e 36 graus de liberdade no denominador valor de interpolação); 
06) a comparação das médias amostrais através do Teste de Tukey, $\alpha=5 \%$, para o fator de variação parede mesial demonstrou não haver realmente diferenças estatisticamente significantes entre os quatro grupos experimentais (Tabela An.C27);

07) a comparação das médias amostrais através do Teste de Tukey, $\alpha=5 \%$, para o fator de variação parede distal (Tabela An.C28) demonstrou haver diferença estatisticamente significante entre os grupos experimentais \#1(Broca Gates-Glidden) e \#3 (Profile ${ }^{\circledR}$ $.04 / .06$ \& Orifice Shapers). A diferença entre as médias dos referidos grupos experimentais - 10,4 - demonstrou-se superior ao Valor crítico de Tukey ou diferença mínima significante calculados $(10,3)$ para o fator parede distal. Dessa forma, o Teste de Tukey demonstra que ao comparar-se a média do G\#1 $(10,7)$ com a do G\#3 $(7,1)$ verifica-se que a primeira foi significativamente maior que a segunda tendo em vista o nível de significância ( $\alpha=5 \%)$ eleito para este experimento;

08) a comparação das médias amostrais através do Teste de Tukey, $\alpha=5 \%$, para o fator de variação paredes mesial e distal (Tabela An.C29) demonstrou haver diferença estatisticamente significante entre os grupos experimentais \#3 (Profile $^{\circledR} .04 / .06$ \& Orifice Shapers) e \#4 (Pow-R ${ }^{\mathrm{TM}}$ Coronal Shapers). A diferença entre as médias dos referidos grupos experimentais - 7,0 - demonstrou-se superior ao Valor crítico de Tukey ou diferença mínima significante calculados $(6,9)$ para o fator paredes mesial e distal. Dessa forma, 
o Teste de Tukey demonstra que ao comparar-se a média do G\#3 $(8,4)$ com a do G\#4 $(15,4)$ verifica-se que a segunda foi significativamente maior que a primeira tendo em vista o nível de significância ( $\alpha=5 \%$ ) eleito para este experimento.

Assim, a avaliação estatística dos resultados experimentais:

01) demonstrou que com relação à parede mesial o Grupo Experimental \#4 (Pow-R ${ }^{\text {TM }}$ Coronal Shapers) apresentou a maior média de desgaste - $12,30 \%$ - entre os quatro grupos experimentais (Tabela An.C18);

02) demonstrou que com relação à parede distal o Grupo Experimental \#1 (Broca Gates-Glidden) apresentou a maior média de desgaste 20,00\% - entre os quatro grupos experimentais (Tabela An.C18);

03) demonstrou que com relação às paredes mesial e distal o Grupo Experimental \#4 (Pow- $\mathrm{R}^{\mathrm{TM}}$ Coronal Shapers) apresentou a maior média de desgaste - 15,40\% - ente os quatro grupos experimentais (Tabela An.C18);

04) demonstrou não ter havido diferenças estatisticamente significantes entre os quatro grupos experimentais avaliados quanto ao desgaste da parede mesial;

05) demonstrou que o preparo com brocas Gates-Glidden (Grupo Experimental \#1) promoveu desgaste significativamente maior da parede distal quando comparado com o do Grupo Experimental \#3 (Profile $^{\circledR} .04 / .06$ \& Orifice Shapers) mas não em relação aos outros grupos; 
06) demonstrou que o preparo com Pow-R ${ }^{\mathrm{TM}}$ Coronal Shapers (Grupo Experimental \#4) promoveu desgaste significativamente maior das paredes mesial e distal quando comparado com o do Grupo Experimental \#3 (Profile ${ }^{\circledR} .04 / .06$ \& Orifice Shapers) mas não em relação aos outros grupos; 


\section{DISCUSSÃO}

Em detrimento de uma abordagem de natureza essencialmente empiricista, almejando exclusivamente o alívio da dor, o avanço tecnocientífico dos últimos cento e cinqüenta anos transformaram a Endodontia em uma ciência complexa e de base racional. Hoje, o tratamento endodôntico implica a consideração de uma gama imensa de aspectos relacionados tanto ao clínico como ao paciente em busca de uma experiência previsível e bem sucedida. A pesquisa microbiológica e a compreensão do papel dos microorganismos na etiopatogenia pulpar e perirradicular, o estudo da anatomia dental evidenciando os aspectos topográficos internos e o conhecimento da biologia pulpar, da primeira metade do século vinte, construíram uma base sólida para as investigações subseqüentes. Os conceitos atuais aludem para um tecido pulpar, no interior de um sistema de canais imersos em uma massa dentinária radicular inelástica, que apesar de confinado pode sediar um número sem fim de diferentes microorganismos e sucumbir. Dentro deste contexto, a terapia endodôntica bem sucedia tornou-se dependente de múltiplos fatores interdependentes com a modelagem e a sanificação (Schilder, 1974) dos canais radiculares ocorrendo 
simultaneamente e ocupando papel de importância relevante no selamento tridimensional e hermético com vistas ao reparo.

Para Wildey \& Senia (1989) a limpeza e a modelagem do sistema de canais radiculares foi e continua sendo um desafio para o mais experiente dos endodontistas.

Assim, no que concerne à modelagem dos canais radiculares, a construção de um espaço endodôntico mecânica e biologicamente adequado foi precocemente percebida como um desafio vistos os resultados nem sempre satisfatórios da interação dos rígidos instrumentos de aço, de secção transversal quadrangular e pouco flexíveis com as paredes internas dos canais curvos. Dessa forma, as deformações da configuração original e a limpeza inadequada dos canais radiculares definiram-se como os principais parâmetros de um número considerável de novas pesquisas. Consequentemente, elaboraram-se novas técnicas de preparo com diferentes seqüências dos instrumentos assim como instrumentos dotados de novas propriedades químicas e físicas. Da mesma forma, novas características geométricas (secções transversais triangulares, losangulares, etc.) conferiram aos instrumentos melhores propriedades mecânicas, i.e. maiores resistências à deflexão e à torção assim como maior capacidade de corte.

Apesar do emprego de brocas Gates-Glidden no preparo dos canais radiculares no fim do século dezenove, somente em 1915, cerca de vinte anos após a fundação da Maillefer, tem-se o patenteamento da lima K pela Kerr. Na década de sessenta, os instrumentos de aço-carbono foram abandonados e o emprego de instrumentos fabricados a partir de ligas de aço inoxidável 
torna-se amplamente difundido. Paralelamente, a grande freqüência de deformações da configuração original dos canais assim como de fraturas dos instrumentos impediram que dispositivos como o Racer e o Giromatic, empregados com limas de aço inoxidável, fossem incorporados à prática clínica (Guerisoli, 1999; Pécora et al., 2000; Leonardo, 1991; De Deus, 1986). Da mesma forma, Abou-Rass \& Jastrab (1982) encontraram melhores resultados com o preparo com brocas Gates-Glidden e Largo-Peeso que com o Giromatic.

Destarte melhores resultados alcançados com as técnicas de escalonamento ápico-cervical em detrimento do preparo do canal curvo pela técnica seriada convencional, somente as técnicas escalonadas cérvico-apicais constituíram, em realidade, avanço significativo na modelagem e sanificação do sistema de canais radiculares. O desgaste da região mais cervical do canal radicular antes da intervenção em seu terço apical, permitindo iniciar o preparo desta região com um instrumento de maior diâmetro, criou melhores perspectivas tanto em relação à manutenção da integridade da forma quanto em relação à descontaminação tendo-se em conta, principalmente, a curvatura do canal e a rigidez dos instrumentos de aço como determinadores do número reduzido e do pequeno calibre dos instrumentos a serem empregados no preparo do terço apical assim como a prevalência considerável de iatrogenias (Mullaney \& Petrich, 1968; Clem, 1969, Schilder, 1974).

Ao pesquisar sobre o preparo de canais estreitos e curvos, como nas raízes mesiovestibulares de molares superiores, mesiais de molares 
inferiores, nos incisivos inferiores e incisivos laterais superiores, Mullaney (1979) conclui ser a abordagem escalonada ápico-cervical provavelmente a melhor forma de alargamento dos canais desde que respeitados os preceitos de ordem técnica.

Para Wildey \& Senia (1989) os canais estreitos e curvos, em especial, constituem desafio tanto para o principiante como para o especialista.

Assim, as primeiras pesquisas sobre o preparo do canal radicular buscaram definir, através da análise de fotografias de secções radiculares transversais ou da análise histológica, quais instrumentos, cinemáticas e técnicas produziam canais circulares, cônicos e afunilados com paredes planas, regulares e livres de remanescentes pulpares (Clem, 1969; Vessey, 1969; Moodnik, 1976, Walton, 1976; Bolanos, 1980) tendo-se em conta, principalmente, as limitações operacionais impostas por canais severamente curvos.

No que tangia à cinemática e à forma a serem estabelecidas com o preparo dos canais radiculares, Vessey em 1969 e Jungman et al. em 1975, obtiveram preparos mais circulares com movimentos de alargamento independentemente do instrumento, lima ou alargador, usado. Klayman \& Brilliant (1975) obtiveram preparos significativamente melhores com o preparo escalonado ápico-cervical associado a broca Gates-Glidden que com a peça de mão Giromatic e alargadores.

Sugerindo movimentos de limagem em detrimento do emprego de movimentos de alargamento, Weine et. al. (1975) são os pioneiros na pesquisa das deformações decorrentes do preparo dos canais radiculares 
curvos através da avaliação de canais simulados em blocos de resina acrílica. A estas deformações os autores chamaram zips, dilacerações resultantes do transporte do canal decorrente como conseqüência da memória molecular dos instrumentos. Os blocos de canais simulados, como metodologia de pesquisa, tiveram ampla repercussão e ainda hoje são amplamente usados, principalmente na avaliação dos preparos com instrumentos rotatórios (Thompson \& Dummer, 1997a, 1997b, 1997c, 1997d, 1998a, 1998b, 1998c, 1998d, 2000; Miranzi, 1999; Bryant et al., 1998a, 1998b, 1999).

Machado et al., 1998 ao compararem, em 90 canais mesiais de primeiros molares inferiores preparados com limas $\mathrm{K}$ de aço inoxidável e brocas Gates-Glidden, o preparo seriado convencional com as técnicas escalonadas ápico-cervical e cérvico-apical verificaram um menor grau de deformação do canal radicular com o preparo escalonado cérvico-apical que com os preparos seriado convencional e escalonado ápico-cervical.

Destarte a proposta do CFS (Canal Finder System) pelo francês Lévy, do ultra-som e do SW por Wildey \& Senia em 1989, somente com o surgimento do instrumento endodôntico fabricado a partir do nitinol pelo Professor Harmeet Walia e seus colaboradores, no Departamento de Endodontia da Faculdade de Odontologia da Universidade de Marquette em Milwaukee-USA em 1988, vislumbraram-se novas perspectivas para fase de preparo dos canais radiculares.

No trabalho acima referido, os pesquisadores relatam que os instrumentos endodônticos fabricados de ligas Nitinol têm de 2 a 3 vezes mais flexibilidade elástica que os de aço inoxidável, assim como uma resistência à 
fratura superior sob movimentos de torção tanto no sentido horário como no sentido antihorário. A resistência superior à fratura foi atribuída à ductilidade da liga de níquel-titânio. Concluíram que os instrumentos endodônticos fabricados de níquel-titânio podem ser promissores no tratamento de canais radiculares curvos.

Segundo Gambarini (1998) tais propriedades físicas das ligas de níquel-titânio lhes confeririam maior capacidade para negociar os canais curvos com redução de iatrogenias e maiores preparos do terço apical de canais curvos mantendo-se a forma original.

Segundo Glickman \& Koch (2000), o que é interessante sobre a liga de níquel-titânio é que esta pode existir tanto em uma como em outra fase cristalina. Em repouso, encontra-se em estágio austenítico mas, sob estresse transforma-se em martensita, o que é conhecido como deformação matensítica e que é típica das ligas superelásticas. Segundo os autores, quando o instrumento flutua entre as transformações, e.g. em rotação e sob torque durante o preparo do canal radicular, o instrumento é mais susceptível á deformação permanente e então fratura, o que pode ser evitado compreendendo-se as limitações do sistema empregado, usando-se velocidade estável sem tensão e de forma passiva sem forçá-los.

Surgem então, os novos dispositivos pneumomecânicos e eletromecânicos para o emprego dos novos instrumentos em movimentos de rotação, mediante torque controlado e velocidade baixa e estável..

De acordo com Lumley et al. (1998) as propriedades únicas das ligas de níquel-titânio permitiram que se fabricassem instrumentos para o uso com 
peça de mão e estes têm se mostrado efetivos no preparo dos canais radiculares.

Do ponto de vista geométrico os padrões de conicidade para limas e alargadores anteriormente especificados, aumento progressivo de $0.02 \mathrm{~mm}$ de $D_{1}$ a $D_{2}$ são abandonados e dos novos índices, .04, .06, .08, .10, etc. decorre uma melhor interatividade do novo instrumento superflexível, em função do baixo módulo de elasticidade do nitinol, com as paredes do canal.

De acordo com Berger (1997) constituem vantagens no uso de limas de conicidade gradual ou progressiva: (i) a eliminação do instrumento memória, (ii) eliminação de instrumentos rotatórios e o risco de fratura, (iii) eliminação do recuo de instrumentos, (iv) procedimentos mais simples (a mesma modelagem do canal produzida pela técnica escalonada), (v) menor risco de compactação de dentina na região apical e conseqüente perda de comprimento de trabalho, assim como (vi) maior flexibilidade (os instrumentos de maior diâmetro terão em sua ponta flexibilidade similar à dos instrumentos de menor diâmetro).

No entanto, Pallotta et al., 1999, ao avaliarem in vitro o poder de corte de limas de níquel-titânio (Nitiflex, Maillefer, Ballaighes, Switzerland) em comparação com limas de aço inoxidável, preparando premolares humanos inferiores curvos, relatam que o poder de corte das limas de níquel-titânio é significativamente menor comparado ao das limas Flexofile em aço inoxidável ,quando avaliados os calibres \#25 e \#30, ao nível de significância de 5\%. 
O primeiro sistema de automatização do preparo dos canais radiculares a utilizar instrumentos fabricados a partir de ligas de níquel-titânio a surgir no mercado foi o NT Sensor (NT Company, EUA) (Barbizan, 1999).

O Sistema Lightspeed (Lightspeed Techonology Inc., USA), criado pelos pesquisadores Steve Senia e William Wildey, patenteado em 1984 e disponível no mercado em 1993, foi desenvolvido para conjugar as propriedades físicas das ligas de níquel-titânio com a geometria dos instrumentos do Sistema Canal Master (Brasseler, Savannah-GA, USA), cujas características de forma básicas consistem em lâminas curtas, como nas brocas Gates-Glidden, e ponta piloto já presente em instrumentos como o Rispi (Micromega, Besançon, France) (Dietschi et al., 2001).

Quanto ao desenho das lâminas, os instrumentos rotatórios disponíveis no mercado podem ser classificados em instrumentos de ação cortante agressiva (Quantec, Hero 642, etc.), com ângulos de transição mais agudos, ou de ação suave (e.g. ProFile, ProFile GT, Lightspeed). Nestes últimos, a disposição espacial das lâminas dos instrumentos tem sido referida como radial land (superfície de apoio) que além de lhes conferir melhor resistência mecânica também lhes permitem atuar de forma mais cêntrica durante o preparo do canal radicular (Dietschi et al., 2001).

O Sistema ProFile constitui um grupo de instrumentos que compreendem os Sistemas ProFile (manual com ponta inativa e conicidade .04 e rotatório nas conicidades .04 e .06 para uso em contra-ângulo em baixa velocidade), ProFile Series 29 (Variable Taper, para uso em contra-ângulo em baixa velocidade), ProFile GT (Greater Taper, disponível nas conicidades .06, 
$.08, .10$ e .12) e o ProFile OS (Orifice Shapers). Segundo orientação do fabricante o grupo OS (Orifice Shapers), 6 instrumentos, foi criado para substituir as brocas Gates-Glidden no preparo da região cervical do canal radicular e também diminuir a incidência de forças de tensão deflexiva sobre os instrumentos subseqüentes (Guerisoli et al. 1999).

Os instrumentos ProFile são instrumentos rotatórios com maior índice de conicidade (o dobro ou triplo do padrão $0.02 \mathrm{~mm}$ ) e com uma geometria única especialmente desenhada para minimizar o estresse do instrumento e, portanto, maximizar sua eficiência. Foram desenvolvidos esperando-se que a conicidade maior ao longo de seu corpo criaria automaticamente o esperado afunilamento do canal radicular e que, também, o emprego de superfícies radiais impediriam uma ação não controlável do instrumento com o conseqüente indesejável transporte do canal (Gambarini, 1998).

De acordo com as especificações do fabricante o Sistema ProFile ${ }^{\circledR} .04$ e .06 são instrumentos rotatórios de níquel-titânio para a instrumentação passiva dos canais radiculares curvos com vistas à criação de uma forma afunilada. Sua ponta de segurança tem um ângulo de transição extremamente pequeno para que se evite a formação de degraus ou o transporte do canal. As superfícies radiais, como conseqüência da usinagem de segmentos com sulcos profundos ou em forma de $U$ (secção transversal em forma de $U$ ), promovem a ejeção dos debris do canal em direção coronária, criando um preparo cérvico-apical afunilado e contínuo. Da mesma forma, os instrumentos OS (Orifice Shapers) são indicados para o preparo eficiente da porção coronária do canal radicular, possuem ponta não cortante e suas 
superfícies radiais promovem sua ação cêntrica e minimiza efeitos de preparo indesejáveis. De acordo com o fabricante ao invés de produzirem cortes paralelos como o fazem as brocas Gates-Glidden, estes instrumentos produzem corte de forma cônica.

Os instrumentos rotatórios do sistema Pow- $\mathrm{R}^{\mathrm{TM}}$ Coronal Shapers são caracterizados pela ponta R patenteada por Roane em 1985, em forma de bala, não cortante, para tornar o preparo da região coronária mais seguro. Estes instrumentos apresentam o segmento ativo derivado da lima Onyx $R$ adaptada para ser empregada em baixa rotação em baixa velocidade. Os instrumentos Pow- $\mathrm{R}^{\mathrm{TM}}$ Taper .02 possuem secção transversal quadrangular, como a lima K, e os instrumentos .04 secção transversal triangular.

Este experimento foi desenvolvido para a comparação dos efeitos de quatro diferentes instrumentos sobre a região cervical do canal radicular, considerando-se a tendência do emprego das técnicas de preparo que prescrevem a abordagem cérvico-apical dos canais radiculares. Para tanto compararam-se dois recursos técnicos há muito empregados no preparo da região cervical dos canais radiculares, aqui representados pelas brocas Gates-Glidden e pelas brocas Largo-Peeso, e dois sistemas de instrumentos rotatórios de níquel-titânio recentemente lançados propostos por seus fabricantes para o preparo da região cervical do canal radicular em detrimento dos instrumentos rotatórios de aço inoxidável. Segundo os fabricantes o grande atributo destes novos recursos seria que em função de sua composição química que os dota de maior flexibilidade que os instrumentos de aço inoxidável e em função de suas novas características geométricas 
estes aturariam, do ponto de vista mecânico, de forma mais cêntrica minimizando a indesejável ocorrência do transporte do canal.

Os métodos empregados neste experimento basearam-se no experimento de Machado (2000) que avaliou, através de radiografias digitais, a variação de área em canais mesiais de molares superiores, ao nível dos terços cervical e médio, preparados com os mesmos instrumentos empregados no atual experimento, i.e. brocas de aço inoxidável (Gates-Glidden e Largo-Peeso) e instrumentos de níquel-titânio (Sistema ProFile $^{\circledR} .04 / .06$ \& Orifice Shapers da Dentisply Maillefer, Ballaigues, Switzerland, e o Sistema Pow-R ${ }^{\mathrm{TM}}$ \& Coronal Shapers da Moyco Union Broach, USA).

No experimento acima referido a pesquisadora encontrou diferenças estatisticamente significantes somente entre o grupo experimental de espécimes preparados com brocas Largo-Peeso e o grupo de espécimes preparados com o Sistema ProFile ${ }^{\circledR} .04 / .06$ \& Orifice Shapers. Da comparação das médias de desgaste promovido pelos dois grupos verificou-se que no primeiro a variação da área do canal radicular foi significativamente maior que a do segundo, diferentemente dos resultados encontrados neste experimento onde não encontrou-se diferenças estatisticamente significantes entre os referidos grupos experimentais. .

No entanto, é preciso ressaltar que apesar da análise da mesma variável e do emprego da mesma metodologia de pesquisa, testando-se inclusive os mesmos instrumentos, enquanto o trabalho de Machado (2000) diz respeito muito mais à capacidade de corte dos instrumentos, o atual 
respeita em essência à verificação da localização espacial das áreas de desgaste em relação ao eixo longitudinal do canal radicular. Embora considerações acerca da geometria dos instrumentos testados, assim como de suas propriedades mecânicas, sejam pertinentes a ambos experimentos, enquanto no primeiro interessa a secção transversal dos instrumentos e consequentemente a disposição espacial das arestas cortantes e a relação destas com a capacidade de corte do instrumento, no segundo interessa a relação destas mesmas geometria e propriedades mecânicas com à capacidade do instrumento em manter-se estável e em posição cêntrica durante o preparo. Em ambos os casos o desempenho do instrumento, de forma multifatorial, guarda relação direta com a composição química e a gemometria dos mesmos, bem como com as propriedades mecânicas decorrentes de sua interação com a estrutura dentinária durante o preparo do canal radicular. Dessa forma, em ambos trabalhos, comparam-se em relação aos instrumentos testados as diferentes composições químicas (aço inoxidável e níquel-titânio), diferentes características geométricas (diferentes disposições espaciais das arestas cortantes, diferentes comprimentos dos segmentos cortantes e diferentes índices de conicidades) e as propriedades mecânicas decorrentes como diferentes resistências à deflexão, à fratura e à torção.

A metodologia de pesquisa empregando canais simulados em blocos de resina e fotografias ou radiografias digitais, aliada à análise iconográfica digital para pesquisa de parâmetros de forma como área e perímetro, 
principalmente, é amplamente empregada no estudo do preparo dos canais radiculares com instrumentos rotatórios de níquel-titânio.

O emprego de blocos de resina oferece a possibilidade de padronização das dimensões do canal radicular, como grau, raio, comprimento da curvatura assim como o diâmetro e o grau de conicidade dos canais, o que uma amostra de dentes naturais não permitiria.

Apesar de Gullickson \& Montgomery (1987) aludirem para que a resina empregada na confecção de canais simulados tem uma dureza diferente da dureza da dentina, Lim \& Webber (1985) não encontraram diferenças significativas entre dentes naturais e canais simulados em resina acrílica ao verificarem a formação de desgastes em forma de ampulheta em ambos os tipos de espécimes.

Considerada a indicação dos fabricantes para o uso dos instrumentos pesquisados para o preparo da região cervical dos canais radiculares e objetivando-se minimizar os efeitos da variabilidade inerente à população da qual a amostra foi extraída, empregou-se um limitador de área radiográfica para a padronização da dimensão vertical a ser radiografada, através de um limitador de área radiográfica. O comprimento estabelecido em $4 \mathrm{~mm}$ baseou-se em tabela de comprimentos anatômicos médios - 11,7mm de comprimento para raízes mesiovestibulares de primeiros molares superiores.

A análise estatística dos dados amostrais deste experimento demonstrou médias de desgaste diferentes para os quatro grupos experimentais, rejeitando a hipótese de nulidade, para os vários fatores de 
variação considerados i.e. parede mesial, parede distal e paredes mesial e distal.

As médias de desgaste para cada fator de variação permitiram observar que em $75 \%$ das vezes, independentemente do grupo experimental analisado, a parede mais desgastada foi a parede distal, ou seja, em $3 / 4$ dos espécimes houve uma tendência ao desgaste da parede distal do canal radicular, em direção à furca, que se supõe decorrente da atuação excêntrica dos instrumentos tanto de aço inoxidável como de níquel-titânio.

Em relação à parede mesial não se verificou diferenças estatisticamente significantes entre os quatro grupos experimentais.

No entanto, quanto à parede distal, as brocas Gates-Glidden desgastaram-na significativamente mais que os instrumentos do Sistema ProFile $^{\circledR} .04 / .06$ \& Orifice Shapers, denotando uma maior capacidade de corte dos primeiros.

Da mesma forma, verificou-se um desgaste de área total significativamente maior pelos instrumentos do Sistema Pow-R ${ }^{\mathrm{TM}}$ \& Coronal Shapers em relação aos instrumentos do Sistema ProFile ${ }^{\circledR} .04 / .06$ \& Orifice Shapers.

Não se verificou perfuração da parede do canal radicular em nenhum dos espécimes independentemente do instrumento utilizado.

Isom et al. (1995) ao avaliarem a espessura da dentina após o preparo da região cervical verificaram que as brocas Gates-Glidden removeram mais dentina que os abridores de orifício M Series. 
De forma similar, Abou-Rass et al. (1982) ao avaliarem preparos para retentores intrarradiculares realizados com brocas Gates-Glidden e Largo-Peeso verificaram perfurações nas paredes distais de raízes mesiais de molares inferiores e proximais das vestibulares de molares superiores e Kessler et al. (1983) verificaram, no preparo de canais mesiais de raízes de molares inferiores, maiores riscos de perfuração quando do preparo cervical manualmente ou com brocas Gates-Glidden que quando do preparo cervical através da técnica de força balanceada.

Pilo et al. (1998) verificaram em premolares inferiores preparados com brocas Gates-Glidden redução da espessura da parede de dentina 35\% maior no sentido mesiodistal que o controle não instrumentado.

Em 1987, Lim \& Stock ao compararem o preparo escalonado com movimentos de alargamento com brocas Gates-Glidden no preparo escalonado com instrumentação anticurvatura, em raízes mesiais de molares inferiores, verificaram maior risco de perfuração a $8 \mathrm{~mm}$ que a $5 \mathrm{~mm}$ do ápice radicular, ou seja, além da região considerada neste experimento.

A tendência dos instrumentos rotatórios em manterem-se em posição cêntrica durante o preparo do canal radicular também foi verificada por Poulsen et al. (1996), Royal et al. (1995), Samyn et al. (1995), Short et al. (1996).

Chan \& Chung verificaram que os instrumentos de níquel-titânio deixaram permanecer maior espessura dentinária em toda a extensão do canal que os de aço inoxidável. 
Zmener et al., 1996, observaram preparos mais cônicos e cêntricos com ProFile ${ }^{\circledR} .04$ Series 29 que com o ultra-som ou o preparo manual com limas de aço inoxidável.

Ao avaliarem o preparo de canais radiculares com instrumentos rotatórios ProFile ${ }^{\circledR} .04$ Series 29 Thompson \& Dummer (1997b) consideraram peculiar a remoção excessiva de resina da parede externa dos canais na região apical da curvatura que sempre esteve associada com áreas amplas e degraus irregulares. Segundo os autores este achado contrasta com o padrão de remoção tecidual característico das limas manuais de aço inoxidável que promovem maior desgaste na parede interna da região apical do canal criando zonas de perigo.

Roig-Cayón et al., 1997, verificaram maior número de preparos circulares com o Lightspeed que com as limas Heliapical, Ultraflex, Flexofile ou Sistema Canal Master U diferentemente dos achados de Thompson \& Dummer, 1997c, em que os preparos com o Lightspeed produziram conicidade e fluxo comprometidos provavelmente, segundo os autores, em função de um preparo escalonado ineficiente.

Kum et al., 2000, compararam o ProFile ${ }^{\circledR} .04$, PfoFile ${ }^{\circledR} .06$, OS \#2, OS \#3, ProFile GT e limas K-Flexofile e observaram o menor desgaste com o ProFile $^{\circledR} .04$.

Bryant et al. (1999) observaram preparos rápidos, efetivos e que produziram formas de preparo de boa qualidade com o preparo de canais simulados com os instrumentos rotatórtios ProFile .04 e .06. 
No que respeita à capacidade de corte assim como à qualidade do preparo de canais radiculares curvos Schäfer et al. (1994) concluem que os instrumentos flexíveis de níquel-titânio são claramente superiores a outros instrumentos testados ao verificarem os melhores resultados com instrumentos de ponta não cortante independentemente de haverem sido acionados por motor ou empregados manualmente pela Técnica de Força Balanceada

Segundo Camps \& Pertot, 1995, a deformação permanente das limas de níquel-titânio quando submetidas a um ângulo de $45^{\circ}$ é nula.

Na análise radiográfica da variação do diâmetro do canal radicular após o preparo com limas Flexofile, Flexogates e o Sistema Canal Master U, Saunders \& Saunders (1994) não encontraram diferenças significativas no percentual médio de aumento da área em todos os grupos testados. O Canal Master $U$ promoveu maior aumento de área do canal radicular aos níveis de 9 e $10 \mathrm{~mm}$ do comprimento de trabalho.

Short et al (1997) também observaram que os instrumentos rotatórios de níquel-titânio (ProFile, Lightspeed, McXim) atuam de forma mais cêntrica que as limas de aço inoxidável (Flex-R), não observando diferenças estatisticamente significantes em quaisquer das regiões avaliadas até os instrumentos \#40..

Diferentemente de instrumentos rotatórios como o Quantec, com arestas agudas, os instrumentos do Sistema ProFile são dotados de radial lands (superfícies de apoio) que o fazem atuar de forma plana e suave. Clinicamente, a sensação de que o instrumento não esteja cortando o tecido 
dentinário pode levar ao exercício de alguma pressão que consequentemente o coloque em posição excêntrica (Dietschi et al., 2001).

O desgaste excêntrico verificado com estes instrumentos no presente experimento poderia assim ser explicado mas não explicaria o mesmo evento em relação aos outros grupos experimentais, principalmente em relação aos instrumentos de ação inoxidável de características físicas totalmente diferentes.

A manutenção da configuração original do canal radicular ocupa, indubitavelmente, papel relevante no prognóstico do tratamento endodôntico e os canais radiculares severamente curvos exigirão a atenção do operador independentemente da técnica ou instrumento empregados em seu preparo, especialmente nos casos de polpa morta. Os instrumentos rotatórios de níquel-titânio deram à Endodontia uma perspectiva mais promissora mas é inquestionável que os princípios básicos biológicos e mecânicos que norteiam a terapia endodôntica ainda devam ser considerados não importando qual seja a panacéia em questão. As propriedades dos instrumentos de níquel-titânio, a superelasticidade e seu desempenho cêntrico, Ihes conferem importância fundamental em meio ao arsenal endodôntico atual.

Parece haver consenso quanto ao emprego de instrumentos acionados mecanicamente em detrimento do uso convencional da limagem Dietschi et al, 2001. 


\section{CONCLUSÕES}

Dadas as condições experimentais estabelecidas, o presente trabalho permite concluir que:

01) as brocas Gates-Glidden, as brocas Largo-Peeso, o Sistema Profile $^{\circledR} .04 / .06$ \& Orifice Shapers e o Sistema Pow- $R^{\mathrm{TM}}$ Coronal Shapers promovem desgaste ao nível da região cervical do canal radicular;

02) as brocas Gates-Glidden, as brocas Largo-Peeso, o Sistema Profile $^{\circledR} .04 / .06$ \& Orifice Shapers assim como o Sistema Pow- $R^{\text {TM }}$ Coronal Shapers promovem desgaste tanto da parede mesial como da parede distal ao nível da região cervical do canal radicular;.

03) as brocas Gates-Glidden, as brocas Largo-Peeso, o Sistema Profile $^{\circledR} .04 / .06$ \& Orifice Shapers assim como o Sistema Pow-R ${ }^{\mathrm{TM}}$ Coronal Shapers tendem a promover em $75 \%$ das vezes maior desgaste da parede distal que da parede mesial ao nível da região cervical do canal radicular;

04) as brocas Gates-Glidden tendem a promover um desgaste significantemente maior da parede distal que o Sistema Profile ${ }^{\circledR} .04 / .06$ \& Orifice Shapers ao nível da região cervical do canal radicular;

05) o Sistema Pow-R ${ }^{\mathrm{TM}}$ Coronal Shapers tende a promover um desgaste significantemente maior da estrutura global (paredes mesial e distal) 
que o Sistema Profile ${ }^{\circledR} .04 / .06$ \& Orifice Shapers ao nível da região cervical do canal radicular.

Da análise dos dados experimentais é lícito inferir que o emprego clínico de qualquer dos instrumentos avaliados exige alguma precaução por parte do operador vista a tendência verificada em se promover um maior desgaste da parede distal do canal radicular em sua região cervical. Uma vez encontrar-se essa próxima à região de furca, ocorrências indesejáveis como o adelgaçamento ou a perfuração da parede seriam evitadas. 
ANEXOS 


\section{ANEXO A}

\section{DADOS AMOSTRAIS}

Tabela An.A1 - Valores originais em pixels, divididos por $10^{2}$, das áreas dos espécimes do Grupo Experimental \#1 antes e após o Preparo Químico-Cirúrgico com Brocas Gates-Glidden

\begin{tabular}{lcccccc}
\hline Esp & \multicolumn{3}{c}{ Antes } & \multicolumn{3}{c}{ Após } \\
\multicolumn{2}{c}{$\begin{array}{c}\text { Área Seccional } \\
\text { Parede } \\
\text { Mesial }\end{array}$} & $\begin{array}{c}\text { Parede } \\
\text { Distal }\end{array}$ & $\begin{array}{c}\text { Área Total } \\
\text { Paredes } \\
\text { Mesial e } \\
\text { Distal }\end{array}$ & $\begin{array}{c}\text { Área Seccional } \\
\text { Parede } \\
\text { Mesial }\end{array}$ & $\begin{array}{c}\text { Parede } \\
\text { Distal }\end{array}$ & $\begin{array}{c}\text { Área Total } \\
\text { Paredes } \\
\text { Mesial e } \\
\text { Distal }\end{array}$ \\
\hline 01 & 188,81 & 149,07 & 337,88 & 170,76 & 138,58 & 309,34 \\
02 & 199,15 & 106,42 & 305,57 & 177,42 & 77,71 & 255,13 \\
03 & 141,37 & 174,54 & 315,91 & 136,69 & 144,25 & 280,94 \\
04 & 188,55 & 160,65 & 349,20 & 171,54 & 140,86 & 312,40 \\
05 & 163,07 & 112,86 & 275,93 & 161,15 & 96,57 & 257,72 \\
06 & 164,42 & 140,55 & 304,97 & 125,71 & 123,63 & 249,34 \\
07 & 181,32 & 120,47 & 301,79 & 148,96 & 86,95 & 235,91 \\
08 & 135,27 & 116,32 & 251,59 & 131,22 & 74,71 & 205,93 \\
09 & 168,95 & 152,92 & 321,87 & 148,47 & 118,31 & 266,78 \\
10 & 196,43 & 200,15 & 396,58 & 157,14 & 147,46 & 304,60 \\
\hline
\end{tabular}

Tabela An.A2 - Valores originais em pixels, divididos por $10^{2}$, das áreas dos espécimes do Grupo Experimental \#2 antes e após o Preparo Químico-Cirúrgico com Brocas Largo-Peeso

\begin{tabular}{|c|c|c|c|c|c|c|}
\hline \multirow[t]{3}{*}{ Esp } & \multicolumn{3}{|c|}{ Antes } & \multicolumn{3}{|c|}{ Após } \\
\hline & \multicolumn{2}{|c|}{ Área Seccional } & \multirow{2}{*}{$\begin{array}{c}\text { Área Total } \\
\text { Paredes } \\
\text { Mesial e } \\
\text { Distal }\end{array}$} & \multicolumn{2}{|c|}{ Área Seccional } & \multirow{2}{*}{$\begin{array}{c}\text { Área Total } \\
\text { Paredes } \\
\text { Mesial e } \\
\text { Distal }\end{array}$} \\
\hline & $\begin{array}{c}\text { Parede } \\
\text { Mesial }\end{array}$ & $\begin{array}{c}\text { Parede } \\
\text { Distal }\end{array}$ & & $\begin{array}{c}\text { Parede } \\
\text { Mesial }\end{array}$ & $\begin{array}{c}\text { Parede } \\
\text { Distal }\end{array}$ & \\
\hline 01 & 145,88 & 113,62 & 259,50 & 132,89 & 93,45 & 226,34 \\
\hline 02 & 250,46 & 298,02 & 548,48 & 218,91 & 242,02 & 460,93 \\
\hline 03 & 210,94 & 136,22 & 347,16 & 188,92 & 101,88 & 290,80 \\
\hline 04 & 194,13 & 170,67 & 364,80 & 179,11 & 168,16 & 347,27 \\
\hline 05 & 133,65 & 119,58 & 253,23 & 128,37 & 89,65 & 218,02 \\
\hline 06 & 195,20 & 189,05 & 384,25 & 163,25 & 152,59 & 315,84 \\
\hline 07 & 170,57 & 248,06 & 418,63 & 145,33 & 213,95 & 359,28 \\
\hline 08 & 152,06 & 159,71 & 311,77 & 133,81 & 134,71 & 268,52 \\
\hline 09 & 190,36 & 183,71 & 374,07 & 181,04 & 148,17 & 329,21 \\
\hline 10 & 172,93 & 240,13 & 413,06 & 162,69 & 178,66 & 341,35 \\
\hline
\end{tabular}


Tabela An.A3 - Valores originais em pixels, divididos por $10^{2}$, das áreas dos espécimes do Grupo Experimental \#3 antes e após o Preparo Químico-Cirúrgico com Profile $®$.04 e .06 \& Orifice Shapers

\begin{tabular}{lcccccc}
\hline Esp & \multicolumn{3}{c}{ Antes } & \multicolumn{3}{c}{ Após } \\
\multicolumn{2}{c}{$\begin{array}{c}\text { Área Seccional } \\
\text { Parede } \\
\text { Mesial }\end{array}$} & $\begin{array}{c}\text { Parede } \\
\text { Distal }\end{array}$ & $\begin{array}{c}\text { Área Total } \\
\text { Paredes } \\
\text { Mesial e } \\
\text { Distal }\end{array}$ & $\begin{array}{c}\text { Área Seccional } \\
\text { Parede } \\
\text { Mesial }\end{array}$ & $\begin{array}{c}\text { Parede } \\
\text { Distal }\end{array}$ & $\begin{array}{c}\text { Área Total } \\
\text { Paredes } \\
\text { Mesial e } \\
\text { Distal }\end{array}$ \\
\hline 01 & 170,05 & 159,21 & 329,26 & 160,14 & 153,85 & 313,99 \\
02 & 159,67 & 131,63 & 291,30 & 145,54 & 128,81 & 274,35 \\
03 & 234,55 & 211,42 & 445,97 & 225,47 & 206,61 & 432,08 \\
04 & 159,96 & 175,05 & 335,01 & 141,43 & 161,57 & 303,00 \\
05 & 192,77 & 132,08 & 324,85 & 173,06 & 109,73 & 282,79 \\
06 & 106,91 & 119,36 & 226,27 & 104,57 & 107,22 & 211,79 \\
07 & 222,70 & 207,11 & 429,81 & 205,04 & 197,80 & 402,84 \\
08 & 182,60 & 191,47 & 374,07 & 180,00 & 183,88 & 363,88 \\
09 & 211,15 & 180,37 & 391,52 & 180,84 & 141,30 & 322,14 \\
10 & 129,71 & 172,27 & 301,98 & 115,71 & 123,40 & 239,11 \\
\hline
\end{tabular}

Tabela An.A4 - Valores originais em pixels, divididos por $10^{2}$, das áreas dos espécimes do Grupo Experimental \#4 antes e após o Preparo Químico-Cirúrgico com Pow-R ${ }^{\text {TM }}$ Coronal Shapers

\begin{tabular}{lcccccc}
\hline Esp & \multicolumn{3}{c}{ Antes } & \multicolumn{3}{c}{ Após } \\
& $\begin{array}{c}\text { Área Seccional } \\
\text { Parede } \\
\text { Mesial }\end{array}$ & $\begin{array}{c}\text { Parede } \\
\text { Distal }\end{array}$ & $\begin{array}{c}\text { Área Total } \\
\text { Paredes } \\
\text { Mesial e } \\
\text { Distal }\end{array}$ & $\begin{array}{c}\text { Área Seccional } \\
\text { Parede } \\
\text { Mesial }\end{array}$ & $\begin{array}{c}\text { Parede } \\
\text { Distal }\end{array}$ & $\begin{array}{c}\text { Área Total } \\
\text { Paredes } \\
\text { Mesial e } \\
\text { Distal }\end{array}$ \\
\hline 01 & 122,89 & 106,79 & 229,68 & 101,93 & 71,63 & 173,56 \\
02 & 155,52 & 143,16 & 298,68 & 145,38 & 129,30 & 274,68 \\
03 & 156,74 & 137,08 & 293,82 & 124,95 & 94,54 & 219,49 \\
04 & 147,49 & 169,80 & 317,29 & 130,89 & 157,04 & 287,93 \\
05 & 127,70 & 127,97 & 255,67 & 108,04 & 108,53 & 216,57 \\
06 & 148,46 & 220,99 & 369,45 & 140,38 & 182,55 & 322,93 \\
07 & 195,61 & 179,09 & 374,70 & 191,94 & 161,52 & 353,46 \\
08 & 139,47 & 122,82 & 262,29 & 115,44 & 98,07 & 213,51 \\
09 & 107,53 & 121,07 & 228,60 & 90,84 & 98,95 & 189,79 \\
10 & 152,70 & 152,27 & 304,97 & 127,73 & 109,85 & 237,58 \\
\hline
\end{tabular}


Tabela An.A5 - Valores das variações de área dos espécimes do Grupo Experimental \#1 após o Preparo Químico-Cirúrgico com Brocas Gates-Glidden

\begin{tabular}{|c|c|c|c|c|c|c|}
\hline \multirow[t]{3}{*}{ Esp. } & \multicolumn{6}{|c|}{$\begin{array}{c}\text { Variação de Área } \\
\text { Grupo Experimental \#1 - G1 - Preparo com Brocas Gates-Glidden } \\
\text { Área Seccional }\end{array}$} \\
\hline & \multicolumn{2}{|c|}{ Parede Mesial } & \multicolumn{2}{|c|}{ Parede Distal } & \multicolumn{2}{|c|}{$\begin{array}{c}\text { Parede Mesial e Parede } \\
\text { Distal }\end{array}$} \\
\hline & VA & VR & VA & VR & VA & VR \\
\hline 01 & 18,21 & 9,64 & 10,49 & 7,04 & 28,54 & 8,45 \\
\hline 02 & 21,73 & 10,91 & 28,71 & 26,98 & 50,44 & 16,51 \\
\hline 03 & 4,68 & 3,31 & 30,29 & 17,35 & 34,97 & 11,07 \\
\hline 04 & 17,01 & 9,02 & 19,79 & 12,32 & 36,80 & 10,54 \\
\hline 05 & 1,92 & 1,18 & 16,29 & 14,43 & 18,21 & 6,60 \\
\hline 06 & 38,71 & 23,54 & 16,92 & 12,04 & 55,63 & 18,24 \\
\hline 07 & 32,96 & 18,18 & 33,52 & 27,82 & 65,88 & 21,83 \\
\hline 08 & 4,05 & 2,99 & 41,61 & 35,78 & 45,66 & 18,15 \\
\hline 09 & 20,48 & 12,12 & 34,61 & 22,63 & 55,09 & 17,12 \\
\hline 10 & 39,29 & 20,00 & 52,69 & 28,12 & 91,98 & 23,19 \\
\hline
\end{tabular}

Tabela An.A6 - Valores das variações de área dos espécimes do Grupo Experimental \#2 após o Preparo Químico-Cirúrgico com Brocas Largo-Peeso

\begin{tabular}{|c|c|c|c|c|c|c|}
\hline \multirow[t]{3}{*}{ Esp. } & \multicolumn{6}{|c|}{$\begin{array}{c}\text { Variação de Área } \\
\text { Grupo Experimental \#2 - G2 - Preparo com Brocas Largo-Peeso }\end{array}$} \\
\hline & \multicolumn{2}{|c|}{ Parede Mesial } & \multicolumn{2}{|c|}{ Parede Distal } & \multicolumn{2}{|c|}{$\begin{array}{c}\text { Parede Mesial e Parede } \\
\text { Distal }\end{array}$} \\
\hline & VA & VR & VA & VR & VA & VR \\
\hline 01 & 12,99 & 8,90 & 20,17 & 17,75 & 33,16 & 12,78 \\
\hline 02 & 31,55 & 12,60 & 56,00 & 18,80 & 87,55 & 15,96 \\
\hline 03 & 22,02 & 10,44 & 34,34 & 25,21 & 56,36 & 16,23 \\
\hline 04 & 15.02 & 7,74 & 2,51 & 1,47 & 17,53 & 4,80 \\
\hline 05 & 5,28 & 3,95 & 19,93 & 16,67 & 35,21 & 13,90 \\
\hline 06 & 31,95 & 16,37 & 36,46 & 19,28 & 68,41 & 17,80 \\
\hline 07 & 25,24 & 14,80 & 34,11 & 13,75 & 59,35 & 14,18 \\
\hline 08 & 18,25 & 12,00 & 25,00 & 15,65 & 43,25 & 13,87 \\
\hline 09 & 9,32 & 4,89 & 35,54 & 19,34 & 44,86 & 11,99 \\
\hline 10 & 10,24 & 5,92 & 61,47 & 25,60 & 71,71 & 17,36 \\
\hline
\end{tabular}


Tabela An.A7 - Valores das variações de área dos espécimes do Grupo Experimental \#3 após o Preparo Químico-Cirúrgico com Profile ${ }^{\circledR} .04$ e .06 \& Orifice Shapers

\begin{tabular}{|c|c|c|c|c|c|c|}
\hline $\begin{array}{r}\text { Gr } \\
\text { Esp. }\end{array}$ & Expe & \#3 - & $\begin{array}{l}\text { ariação } \\
\text { Preparo } \\
\text { ional }\end{array}$ & $\begin{array}{l}\text { rea } \\
\text { Profile }\end{array}$ & 1/.06 \& Or & $\begin{array}{l}\text { Shapers } \\
\text { otal }\end{array}$ \\
\hline & Pare & esial & Pare & istal & Parede N & $\begin{array}{l}\text { I e Parede } \\
\text { | }\end{array}$ \\
\hline & VA & VR & VA & VR & VA & VR \\
\hline 01 & 9,91 & 5,83 & 5,36 & 3,37 & 15,27 & $4,64 \%$ \\
\hline 02 & 14,13 & 8,85 & 2,82 & 2,14 & 16,95 & 5,82 \\
\hline 03 & 9,08 & 3,87 & 4,81 & 2,27 & 13,89 & $3,11 \%$ \\
\hline 04 & 18,53 & 11,58 & 13,48 & 7,70 & 32,01 & 9,55 \\
\hline 05 & 19,71 & 10,22 & 22,35 & 16,92 & 42,06 & $12,95 \%$ \\
\hline 06 & 2,34 & 2,19 & 12,14 & 10,17 & 14,48 & 6,40 \\
\hline 07 & 17,66 & 7,92 & 9,31 & 4,49 & 26,97 & $6,27 \%$ \\
\hline 08 & 2,60 & 1,42 & 7,59 & 3,96 & 10,19 & 2,72 \\
\hline 09 & 30,31 & 14,35 & 39,07 & 21,66 & 69,38 & 17,72 \\
\hline 10 & 14,00 & 10,79 & 48,87 & 28,37 & 62,87 & 20,82 \\
\hline
\end{tabular}

Tabela An.A8 - Valores das variações de área dos espécimes do Grupo Experimental \#4 após o Preparo Químico-Cirúrgico com Pow-R ${ }^{\text {TM }}$ Coronal Shapers

\begin{tabular}{|c|c|c|c|c|c|c|}
\hline \multirow{4}{*}{ Esp. } & \multicolumn{6}{|c|}{$\begin{array}{c}\text { Variação de Área } \\
\text { Grupo Experimental \#4 - G4 - Preparo com Pow-R Coronal Shapers }\end{array}$} \\
\hline & \multicolumn{4}{|c|}{ Área Seccional } & \multirow{2}{*}{\multicolumn{2}{|c|}{$\begin{array}{c}\text { Área Total } \\
\text { Parede Mesial e Parede } \\
\text { Distal }\end{array}$}} \\
\hline & \multicolumn{2}{|c|}{ Parede Mesial } & \multicolumn{2}{|c|}{ Parede Distal } & & \\
\hline & VA & VR & VA & VR & VA & VR \\
\hline 01 & 20,96 & 17,05 & 35,16 & 32,92 & 56,12 & 24,43 \\
\hline 02 & 10,14 & 6,52 & 13,86 & 9,68 & 24,00 & $8,03 \%$ \\
\hline 03 & 31,79 & $20,28 \%$ & 42,54 & 31,03 & 74,33 & 25,30 \\
\hline 04 & 16,60 & $11,25 \%$ & 12,76 & $7,51 \%$ & 29,36 & 9,25 \\
\hline 05 & 19,66 & $15,39 \%$ & 19,44 & 15,19 & 39,10 & 15,29 \\
\hline 06 & 8,08 & 5,44 & 38,44 & $17,39 \%$ & 46,52 & 12,59 \\
\hline 07 & 3,67 & 1,88 & 17,57 & 9,81 & 21,24 & 5,67 \\
\hline 08 & 24,03 & 17,23 & 24,75 & 20,15 & 48,78 & 18,60 \\
\hline 09 & 16,69 & 15,52 & 22,12 & 18,27 & 38,81 & 16,98 \\
\hline 10 & 24,97 & 16,35 & 42,42 & 27,86 & 67,39 & 22,10 \\
\hline
\end{tabular}

VA - Valor Absoluto em pixels VR - Valor Relativo em percentuais de pixels 
ANEXO B

\section{ANÁLISE ESTATÍSTICA}

\section{ANÁLISE DOS VALORES DE VARIAÇÃO DE ÁREA NAS AMOSTRAS}

\section{TESTES DE NORMALIDADE}

1) Teste de Normalidade das variações de área das paredes mesiais.

Tabela An.B9 - Teste de Normalidade das variações de área das paredes mesiais das amostras - Parâmetros Amostrais

\begin{tabular}{c|l}
\hline Parâmetros & \multicolumn{1}{c}{ Valores } \\
\hline Soma dos dados amostrais & 0.0000 \\
Soma dos quadrados dos dados & 1370.4000 \\
Termo de Correção & 0.0000 \\
Variação total & 1370.4000 \\
Média Geral da Amostra & 0.0000 \\
Variância da amostra & 35.1385 \\
Desvio padrão da amostra & 5.9278 \\
Erro padrão da média & 0.9373 \\
Mediana por dados agrupados & 0.0000 \\
Número de dados da amostra & 0.0000 \\
Dados abaixo da média & 0.0000 \\
Dados iguais à média & 0.0000 \\
Dados acima da média & 0.0000 \\
\hline
\end{tabular}

Tabela An.B10 - Teste de Normalidade das variações de área das paredes mesiais das amostras - Distribuição de Freqüências

\begin{tabular}{|c|c|c|c|c|c|c|c|c|}
\hline & & M-3s & $M-2 s$ & M-1s & Med. & $M+1 s$ & $M+2 s$ & $M+3 s$ \\
\hline \multirow{2}{*}{$\begin{array}{c}\text { Por intervalos } \\
\text { de classe }\end{array}$} & Absolutas & 0 & 0 & 13 & 15 & 9 & 3 & 0 \\
\hline & Percentuais & 0.0 & 0.0 & 32.5 & 37.5 & 22.5 & 7.5 & 0.0 \\
\hline \multirow[t]{2}{*}{ Acumuladas } & Absolutas & 0 & 0 & 13 & 28 & 37 & 40 & 40 \\
\hline & Percentuais & 0.0 & 0.0 & 32.5 & 70.0 & 92.5 & 100.0 & 100.0 \\
\hline
\end{tabular}


Tabela An.B11 - Teste de Normalidade das variações de área das paredes mesiais doas amostras - Teste de Aderência

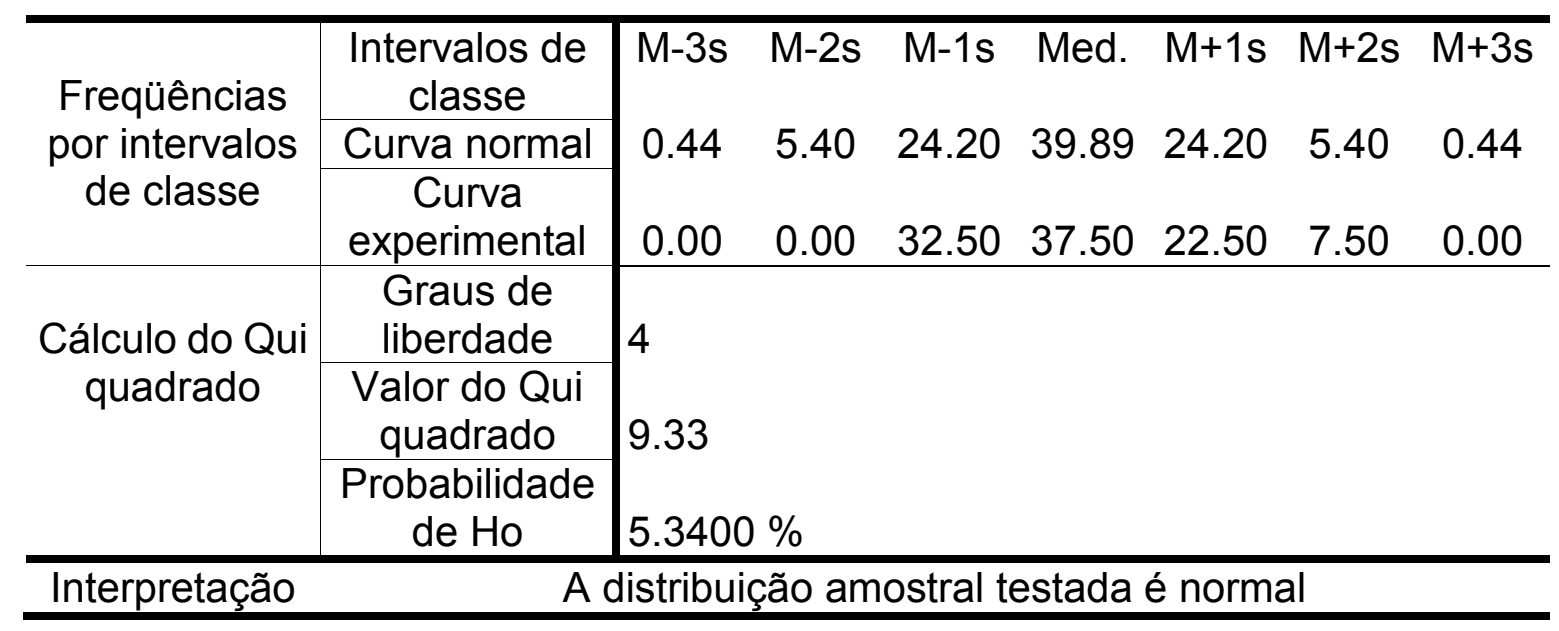

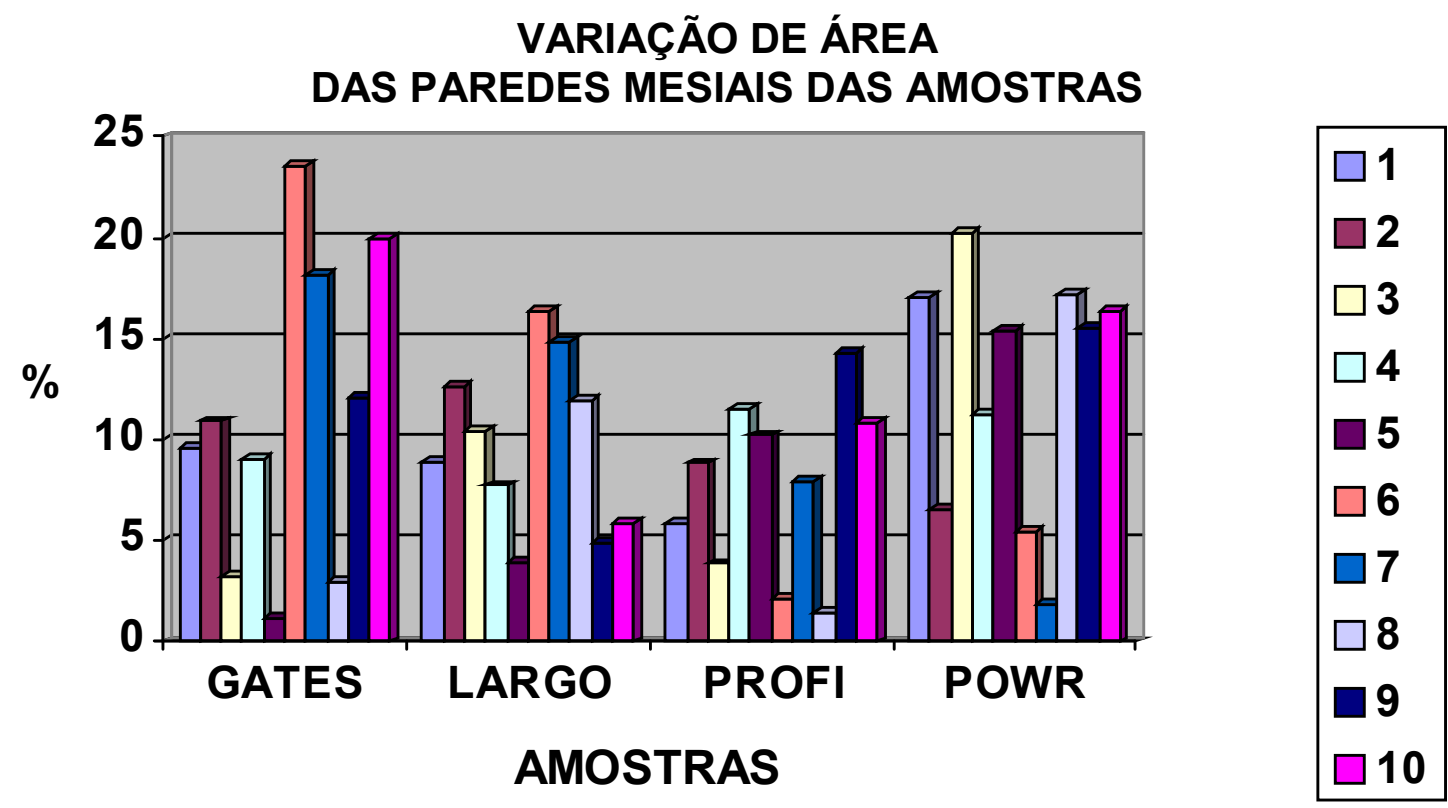

Gráfico An.B1- Variação de área das paredes mesiais nas amostras 


\section{2) Teste de Normalidade das variações de área das paredes distais.}

Tabela An.B12 - Teste de Normalidade das variações de área das paredes distais das amostras - Parâmetros Amostrais

\begin{tabular}{c|l}
\hline Parâmetros & \multicolumn{1}{c}{ Valores } \\
\hline Soma dos dados amostrais & 0.0000 \\
Soma dos quadrados dos dados & 3260.9751 \\
Termo de Correção & 0.0000 \\
Variação total & 3260.9751 \\
Média Geral da Amostra & 0.0000 \\
Variância da amostra & 83.6147 \\
Desvio padrão da amostra & 9.1441 \\
Erro padrão da média & 1.4458 \\
Mediana por dados agrupados & 0.0000 \\
Número de dados da amostra & 0.0000 \\
Dados abaixo da média & 0.0000 \\
Dados iguais à média & 0.0000 \\
Dados acima da média & 0.0000 \\
\hline
\end{tabular}

Tabela An.B13 - Teste de Normalidade das variações de área das paredes distais das amostras - Distribuição de Freqüências

\begin{tabular}{c|c|ccccccc}
\hline & & $\mathrm{M}-3 \mathrm{~s}$ & $\mathrm{M}-2 \mathrm{~s}$ & $\mathrm{M}-1 \mathrm{~s}$ & Med. & $\mathrm{M}+1 \mathrm{~s}$ & $\mathrm{M}+2 \mathrm{~s}$ & $\mathrm{M}+3 \mathrm{~s}$ \\
\hline Por intervalos & Absolutas & 0 & 3 & 9 & 16 & 9 & 3 & 0 \\
\cline { 2 - 8 } de classe & Percentuais & 0.0 & 7.5 & 22.5 & 40.0 & 22.5 & 7.5 & 0.0 \\
\hline \multirow{2}{*}{ Acumuladas } & Absolutas & 0 & 3 & 12 & 28 & 37 & 40 & 40 \\
& Percentuais & 0.0 & 7.5 & 30.0 & 70.0 & 92.5 & 100.0 & 100.0 \\
\hline
\end{tabular}

Tabela An.B14 - Teste de Normalidade das variações de área das paredes distais das amostras - Teste de Aderência

\begin{tabular}{|c|c|c|c|c|c|c|c|c|}
\hline \multirow{3}{*}{$\begin{array}{l}\text { Freqüências } \\
\text { por intervalos } \\
\text { de classe }\end{array}$} & $\begin{array}{l}\text { Intervalos de } \\
\text { classe }\end{array}$ & M-3s & $\mathrm{M}-2 \mathrm{~s}$ & $\mathrm{M}-1 \mathrm{~s}$ & Med. & $\mathrm{M}+1 \mathrm{~s}$ & $\mathrm{M}+2 \mathrm{~s}$ & $M+3 s$ \\
\hline & Curva normal & 0.44 & 5.40 & 24.20 & 39.89 & 24.20 & 5.40 & 0.44 \\
\hline & $\begin{array}{c}\text { Curva } \\
\text { experimental }\end{array}$ & & & & & & & \\
\hline \multirow[t]{2}{*}{$\begin{array}{l}\text { Cálculo do Qui } \\
\text { quadrado }\end{array}$} & $\begin{array}{l}\text { Graus de } \\
\text { liberdade }\end{array}$ & \multirow{2}{*}{\multicolumn{7}{|c|}{1.87}} \\
\hline & $\begin{array}{c}\text { Valor do Qui } \\
\text { quadrado } \\
\text { Probabilidade } \\
\text { de Ho }\end{array}$ & & & & & & & \\
\hline Interpretação & \multicolumn{8}{|c|}{ A distribuição amostral testada é normal } \\
\hline
\end{tabular}




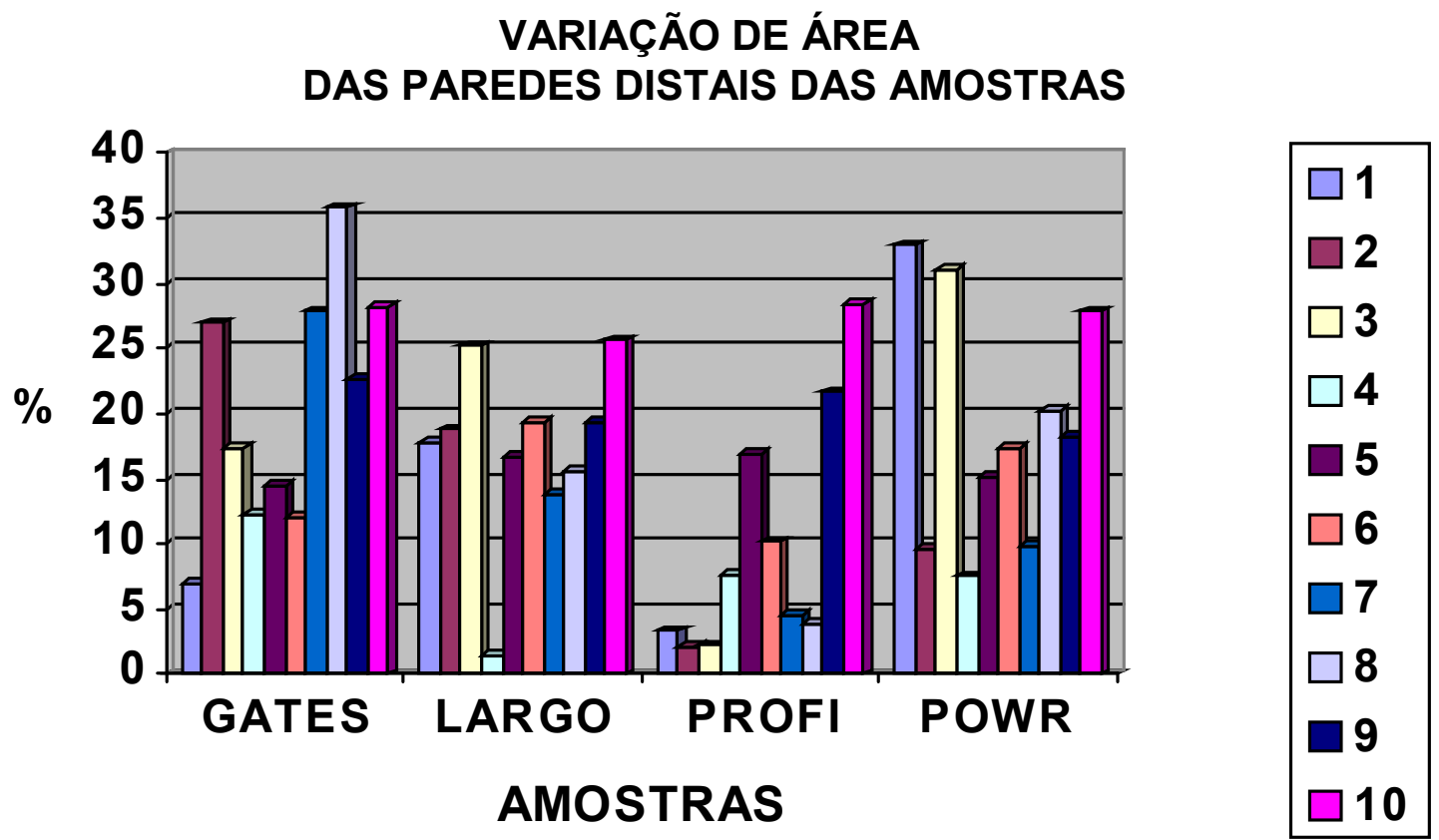

Gráfico An.B2- Variação de área das paredes distais nas amostras

3) Teste de Normalidade das variações de área total - paredes mesial e distal

Tabela An.B15 - Teste de Normalidade das variações de área total (paredes mesial e distal ) das amostras - Parâmetros Amostrais

\begin{tabular}{c|l}
\hline Parâmetros & \multicolumn{1}{c}{ Valores } \\
\hline Soma dos dados amostrais & 0.0000 \\
Soma dos quadrados dos dados & 1493.8999 \\
Termo de Correção & 0.0000 \\
Variação total & 1493.8999 \\
Média Geral da Amostra & 0.0000 \\
Variância da amostra & 38.3051 \\
Desvio padrão da amostra & 6.1891 \\
Erro padrão da média & 0.9786 \\
Mediana por dados agrupados & 0.0000 \\
Número de dados da amostra & 0.0000 \\
Dados abaixo da média & 0.0000 \\
Dados iguais à média & 0.0000 \\
Dados acima da média & 0.0000 \\
\hline
\end{tabular}


Tabela An.B16 - Teste de Normalidade das variações de área total (paredes mesial e distal) das amostras - Distribuição de Freqüências

\begin{tabular}{c|c|cccccccc}
\hline & & M-3s & M-2s & M-1s & Med. & M+1s & M+2s & M+3s \\
\hline Por intervalos & Absolutas & 0 & 2 & 11 & 14 & 10 & 3 & 0 \\
de classe & Percentuais & 0.0 & 5.0 & 27.5 & 35.0 & 25.0 & 7.5 & 0.0 \\
\cline { 2 - 8 } Acumuladas & Absolutas & 0 & 2 & 13 & 27 & 37 & 40 & 40 \\
\cline { 2 - 8 } & Percentuais & 0.0 & 5.0 & 32.5 & 67.5 & 92.5 & 100.0 & 100.0 \\
\hline
\end{tabular}

Tabela An.B17 - Teste de Normalidade das variações de área total (paredes mesial e distal) das amostras - Teste de Aderência

\begin{tabular}{|c|c|c|c|c|c|c|c|c|}
\hline \multirow{3}{*}{$\begin{array}{l}\text { Freqüências } \\
\text { por intervalos } \\
\text { de classe }\end{array}$} & $\begin{array}{l}\text { Intervalos de } \\
\text { classe }\end{array}$ & M-3s & M-2s & M-1s & Med. & $M+1 s$ & $M+2 s$ & $M+3 s$ \\
\hline & Curva normal & 0.44 & 5.40 & 24.20 & 39.89 & 24.20 & 5.40 & 0.44 \\
\hline & $\begin{array}{c}\text { Curva } \\
\text { experimental }\end{array}$ & & 5.00 & & & 25.00 & 7.50 & 0.00 \\
\hline \multirow[t]{3}{*}{$\begin{array}{l}\text { Cálculo do Qui } \\
\text { quadrado }\end{array}$} & $\begin{array}{l}\text { Graus de } \\
\text { liberdade }\end{array}$ & \multirow{3}{*}{\multicolumn{2}{|c|}{$\begin{array}{l}4 \\
1.92 \\
75.0100 \%\end{array}$}} & & & & & \\
\hline & $\begin{array}{l}\text { Valor do Qui } \\
\text { quadrado }\end{array}$ & & & & & & & \\
\hline & $\begin{array}{c}\text { Probabilidade } \\
\text { de Ho }\end{array}$ & & & & & & & \\
\hline
\end{tabular}

VARIAÇÃO DE ÁREA TOTAL

PAREDES MESIAL E DISTAL DAS AMOSTRAS

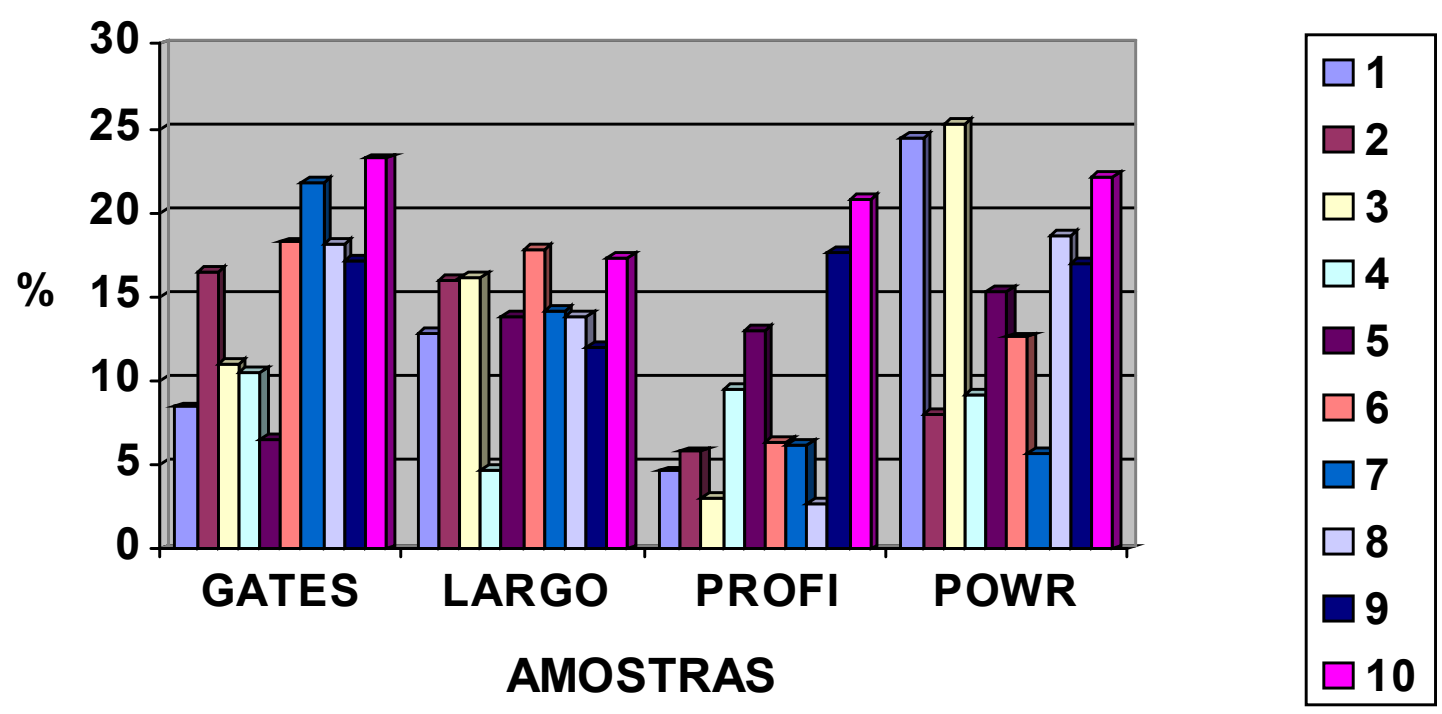

Gráfico An.B3- Variação de área total - parede mesial e parede distal - nas amostras 


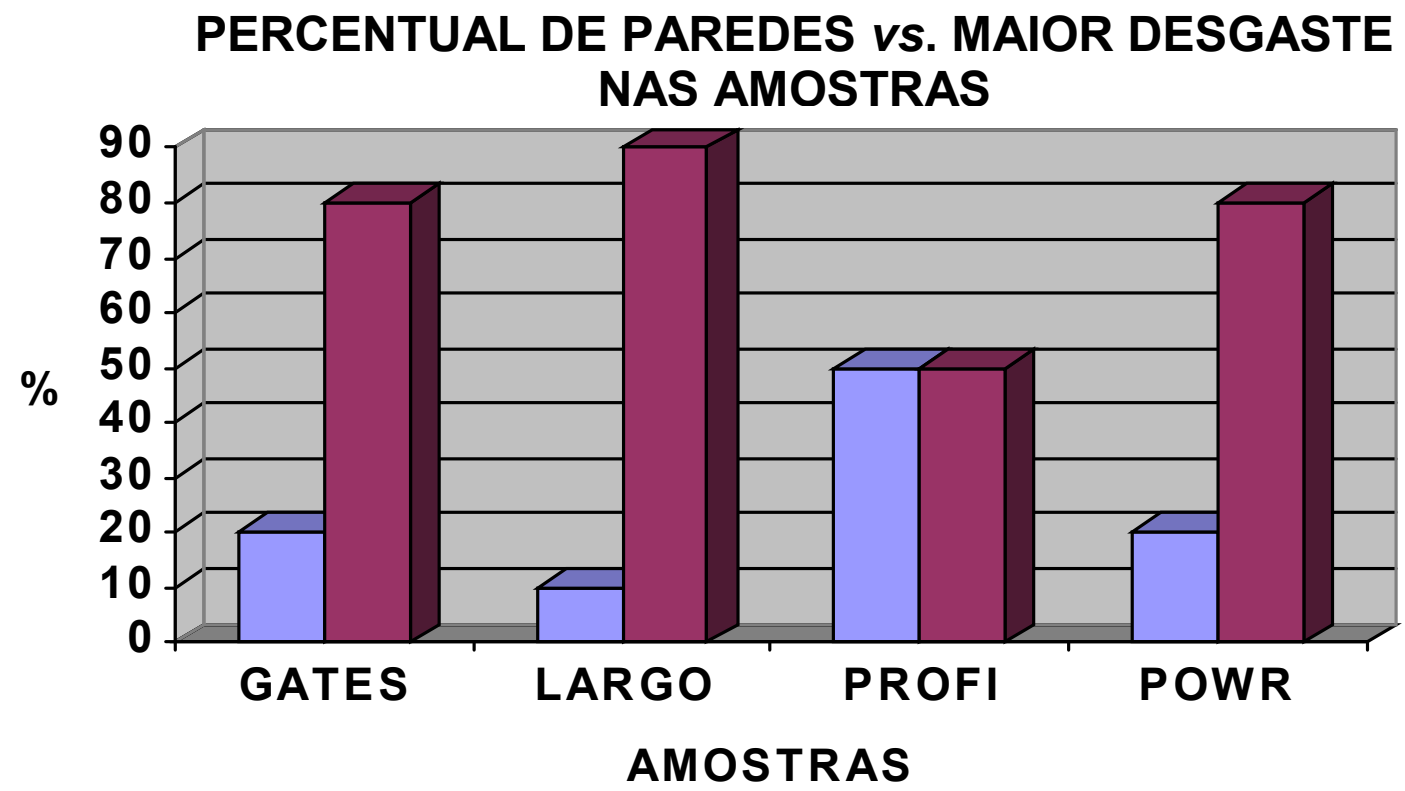

$\square$ MESIAL $\square$ DISTAL

Gráfico An.B4- Percentual de paredes vs. Maior desgaste por amostra 


\section{ANEXO C}

\section{TESTES ESTATÍSTICOS}

\section{PARÂMETROS AMOSTRAIS}

Tabela An.C18 - Parâmetros Amostrais segundo os grupos experimentais e paredes analisadas (valores em percentuais)

\begin{tabular}{cccccc}
\hline Parede & \multicolumn{2}{c}{ Grupo Experimental } & $\begin{array}{c}\text { Média } \\
\text { Aritmética }\end{array}$ & Desvio-Padrão & $\begin{array}{c}\text { Erro-Padrão } \\
\text { da Média }\end{array}$ \\
\hline \multirow{5}{*}{ Mesial } & G\#1 & Gates & 10.70000 & 7.6601 & 2.4223 \\
& G\#2 & Largo & 9.10000 & 4.4083 & 1.3940 \\
& G\#3 & Profile & 7.10000 & 4.2804 & 1.3536 \\
& G\#4 & Pow-R & 12.30000 & 6.2725 & 1.9835 \\
\hline \multirow{5}{*}{ Distal } & G\#1 & Gates & 20.00000 & 8.9443 & 2.8284 \\
& G\#2 & Largo & 16.80000 & 6.7791 & 2.1437 \\
& G\#4 & Profile & 9.60000 & 9.1311 & 2.8875 \\
Mesial e & Pow-R & 18.50000 & 9.0707 & 2.8684 \\
Distal & G\#3 & Gates & 14.80000 & 5.7116 & 1.8062 \\
& G\#4 & Largo & 13.20000 & 3.8239 & 1.2092 \\
\hline
\end{tabular}

Tabela An.C19 - Parâmetros amostrais das variações de área segundo as paredes analisadas

\begin{tabular}{|c|c|c|c|}
\hline Parâmetros & Mesial & $\begin{array}{l}\text { Paredes } \\
\text { Distal }\end{array}$ & Mesial e Distal \\
\hline Soma dos dados & 392.0000 & 649.0000 & 518.0000 \\
\hline Número de dados & 40.0000 & 40.0000 & 40.0000 \\
\hline Soma de quadrados & 5212.0000 & 13791.0000 & 8202.0000 \\
\hline Termo de correção & 3841.6001 & 10530.0254 & 6708.1001 \\
\hline Variação total & 1370.3999 & 3260.9746 & 1493.8999 \\
\hline Graus de liberdade & 39.0000 & 39.0000 & 39.0000 \\
\hline Média da Amostra & 9.8000 & 16.2250 & 12.9500 \\
\hline Variância da amostra & 35.1385 & 83.6147 & 38.3051 \\
\hline Desvio padrão da amostra & 5.9278 & 9.1441 & 6.1891 \\
\hline Erro padrão da média & 0.9373 & 1.4458 & 0.9786 \\
\hline
\end{tabular}




\section{TESTE DE BARTLETT}

Tabela An.C20 - Teste de Homogeneidade de Bartlett das variações de área entre as amostras

\begin{tabular}{|c|c|c|c|}
\hline \multirow[b]{2}{*}{ Parâmetros } & \multicolumn{3}{|c|}{ Paredes } \\
\hline & Mesial & Distal & Mesial-Distal \\
\hline $\begin{array}{c}\text { Graus de liberdade do } \\
\text { numerador }\end{array}$ & $\mathrm{v} 1=3$ & $\mathrm{v} 1=3$ & $\mathrm{v} 1=3$ \\
\hline $\begin{array}{c}\text { Graus de liberdade do } \\
\text { denominador }\end{array}$ & $v 2=2333$ & $v 2=2333$ & $v 2=2333$ \\
\hline $\begin{array}{c}\text { Valor de F calculado } \\
\text { pelo teste }\end{array}$ & $F=1.3752$ & $F=0.3247$ & $F=0.9884$ \\
\hline $\begin{array}{c}\text { Probabilidade de } \\
\text { homogeneidade para } \\
\text { esse valor de } F(v 1, v 2)\end{array}$ & $p=24.72 \%$ & $p=19.00 \%$ & $p=39.85 \%$ \\
\hline Conclusão & $\begin{array}{c}\text { Não-significante } \\
\text { (amostras iguais, } \\
\text { da mesma } \\
\text { população). } \\
\text { Portanto, as } \\
\text { variãncias testadas } \\
\text { são homogêneas } \\
\text { (amostras } \\
\text { homoscedásticas). }\end{array}$ & $\begin{array}{c}\text { Não-significante } \\
\text { (amostras iguais, } \\
\text { da mesma } \\
\text { população). } \\
\text { Portanto, as } \\
\text { variãncias testadas } \\
\text { são homogêneas } \\
\text { (amostras } \\
\text { homoscedásticas). }\end{array}$ & $\begin{array}{c}\text { Não-significante } \\
\text { (amostras iguais, } \\
\text { da mesma } \\
\text { população). } \\
\text { Portanto, as } \\
\text { variãncias testadas } \\
\text { são homogêneas } \\
\text { (amostras } \\
\text { homoscedásticas). }\end{array}$ \\
\hline
\end{tabular}




\section{ANÁLISE DE VARIÂNCIA}

Tabela An.C21 - Análise de Variância das variações de área das paredes mesiais das amostras

\begin{tabular}{cccccc}
\hline \multicolumn{5}{c}{$\begin{array}{c}\text { Análise de Variância } \\
\text { Parede Mesial }\end{array}$} \\
\hline $\begin{array}{c}\text { Fonte de } \\
\text { Variação }\end{array}$ & $\begin{array}{c}\text { Soma de } \\
\text { Quadrados }\end{array}$ & G.L. & $\begin{array}{c}\text { Quadr. } \\
\text { Médios }\end{array}$ & $(\mathrm{F})$ & Prob. (H0) \\
\hline Entre colunas & 148.3999 & 3 & 49.4666 & 1.46 & $24.150 \%$ \\
\hline Resíduo & 1222.0000 & 36 & 33.9444 & & \\
\hline Variação total & 1370.3999 & 39 & & & \\
\hline
\end{tabular}

Tabela An.C22 - Análise de Variância das variações de área das paredes distais das amostras

\begin{tabular}{|c|c|c|c|c|c|}
\hline \multicolumn{6}{|c|}{$\begin{array}{c}\text { Análise de Variância } \\
\text { Parede Distal }\end{array}$} \\
\hline $\begin{array}{l}\text { Fonte de } \\
\text { Variação }\end{array}$ & $\begin{array}{l}\text { Soma de } \\
\text { Quadrados }\end{array}$ & G.L. & $\begin{array}{l}\text { Quadr. } \\
\text { Médios }\end{array}$ & $(F)$ & Prob. (H0) \\
\hline Entre colunas & 636.4746 & 3 & 212.1582 & 2.91 & $4.680 \%$ \\
\hline Resíduo & 2624.5000 & 36 & 72.9028 & & \\
\hline Variação total & 3260.9746 & 39 & & & \\
\hline
\end{tabular}

Tabela An.C23 - Análise de Variância das variações de área total - paredes mesial e distal - das amostras

\begin{tabular}{c|ccccc}
\hline \multicolumn{5}{c}{ Análise de Variãncia } \\
Paredes Mesial-Distal \\
\hline Fonte de & Soma de & G.L. & Quadr. & (F) & Prob. (H0) \\
Variação & Quadrados & & Médios & & \\
\hline Entre colunas & 301.8999 & 3 & 100.6333 & 3.04 & $4.060 \%$ \\
\hline Resíduo & 1192.0000 & 36 & 33.1111 & & \\
\hline Variação total & 1493.8999 & 39 & & & \\
\hline
\end{tabular}

Tabela An.C24 - Valor calculado de F para análise das médias das amostras

Valor de $F(\alpha=5 \%)$ calculado para 4 graus de liberdade no numerador e 36 graus de liberdade no denominador 2,642

Dados da tabela para o denominador: (a) $30-2,69$; (b) $40-2,61$ 


\section{TESTE DE TUKEY}

Tabela An.C25 - Teste de Tukey das variações de área ente as amostras para $\alpha=5 \%$

\begin{tabular}{c|ccc}
\hline Parâmetro & Mesial & $\begin{array}{c}\text { Resultado } \\
\text { Distal }\end{array}$ & $\begin{array}{c}\text { Mesial-Dis } \\
\text { tal }\end{array}$ \\
\hline Resíduo na análise de variância & 33.9444 & 72.9028 & 33.1110 \\
Nível de probabilidade indicado & 5 & 5 & 5 \\
Número de dados da amostra & 40 & 40 & 40 \\
Número de médias comparadas & 4 & 4 & 4 \\
Número de dados para cada média & 10 & 10 & 10 \\
Graus de liberdade do resíduo & 36 & 36 & 36 \\
Valor de q tabelado, (ao nível de 5\%), para 4 & & & \\
médias e 36 graus de liberdade & 3.814 & 3.814 & 3.814 \\
\hline Valor crítico de Tukey calculado & 7.02692 & 10.29800 & 6.94012 \\
\hline
\end{tabular}

Tabela An.C26 - Valor calculado de q para comparação das médias das amostras

Valor de $q(\alpha=5 \%)$ calculado para 4 graus de liberdade no numerador e 36 graus de liberdade no denominador $\mathbf{3 , 8 1 4}$

Dados da tabela para o denominador: (a) $30-3,85$; (b) $40-3,79$

Tabela An.C27 - Valores das diferenças das médias das amostras para a parede mesial

\begin{tabular}{c|ccccccc}
\hline \multicolumn{8}{c}{ Diferença Mínima Significante $=7,03-\alpha=5 \%$} \\
G1 - Gates & 1,6 & $\mathrm{~ns}$ & & & & & \\
G2 - Largo & 1,6 & $\mathrm{~ns}$ & 2,0 & $\mathrm{~ns}$ & & & \\
G3 - Profile & 3,6 & $\mathrm{n}$ & $\mathrm{n}$ & \\
G4 - Pow-R & 1,6 & $\mathrm{~ns}$ & 3,2 & $\mathrm{~ns}$ & 5,2 & $\mathrm{~ns}$ & \\
\hline
\end{tabular}

$\mathrm{s}$ - significante ns - não significante

Tabela An.C28 - Valores das diferenças das médias das amostras para a parede distal

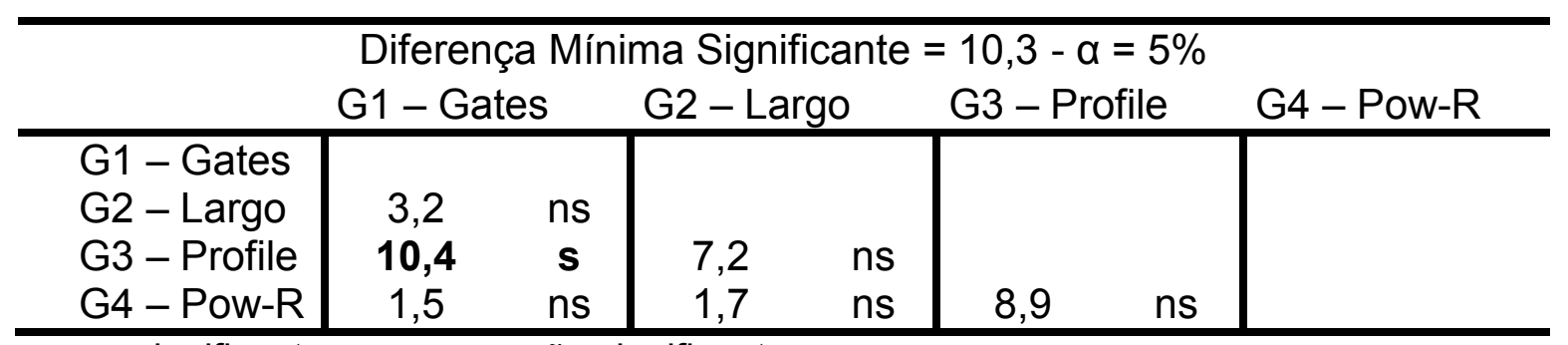

$\mathrm{s}$ - significante ns - não significante 
Tabela An.C29 - Valores das diferenças das médias das amostras para as paredes mesial e distal

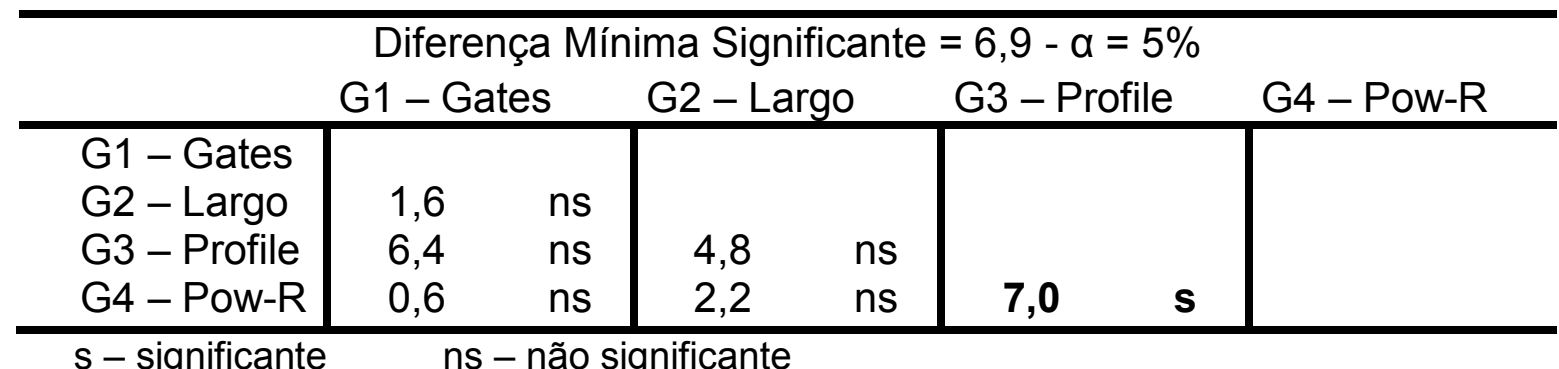

$\mathrm{s}$ - significante ns - não significante

\section{MÉDIAS DE DESGASTE POR AMOSTRA}

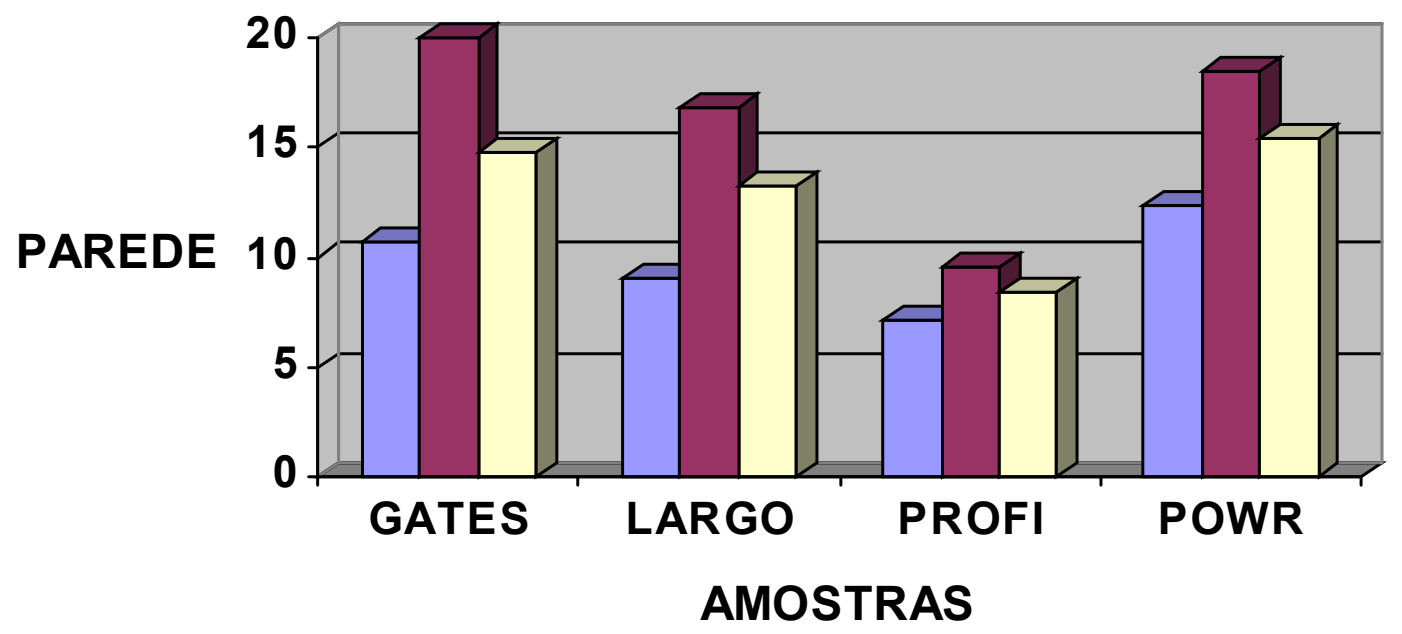

\section{MESIAL $\square$ DISTAL $\square$ TOTAL}

Gráfico An.C5- Médias de desgaste por amostra 


\section{REFERÊNCIAS *}

ABOU-RASS, M.; FRANK, A. L.; GLICK, D. H. The anticurvature filing method to prepare the curved root canal. J Am Dent Assoc, Chicago, v. 101, n. 5, p. 792-794, Nov. 1980.

ABOU-RASS, M.; JASTRAB, R. J. The use of rotary instruments as auxiliary aids to root canal preparation of molars. J Endod, Chicago, v. 8, n. 2, p. 7882, Feb. 1982.

ANDERSON, J. V.; CORCORAN, J. F.; CRAIG, R. G. Cutting ability of square versus rhombus cross-sectional endodontic files. J Endod, Chicago, v. 11, n. 5, p. 212-217, May 1985.

\footnotetext{
* De acordo com ABNT NBR-6023: 2000. Abreviatura de periódicos segundo Bases de Dados MEDLINE.
} 
BAKER, M. C.; ASHRAFI, S. H.; VAN CURA, J. E. Ultrasonic compared with hand instrumentation: a scanning electron microscope study. J Endod, Chicago, v. 14, n. 9, p. 435-440, Sept. 1988.

\section{BARBIZAN, J. V. B. Análise histológica da capacidade de limpeza} promovida pela instrumentação rotatória com limas de níquel-titânio em canais radiculares com achatamento mesio-distal. Ribeirão Preto: 1999. Disponível em: http://www.unaerp.br/odonto/mon_joao.htm. Acesso em: 21 mar. 2001.

BATISTA, A., MATTOS, N. H. R.; SYDNEY, G. B. Avaliação da qualidade do preparo do canal radicular utilizando-se das brocas de Gates-Glidden e dos alaragadores para contra-ângulo. JBC J Bras Odontol Clin, Curitiva, v. 2, n. 7, p. 10-19, Aug 1998.

BASTOS FILHO, E.; PESCE, H. F.; ANTONIAZZI, J. H.; MUENCH, A. Análise "in vitro" da variação angular e da configuração apical quando do preparo de canais curvos com instrumentos de tipo e procedência variados. RBO, Rio de Janeiro, v. 47, n. 5, p. 15-20, Set./Out. 1990.

BEER, R.; BAUMANN, M. A.; KIM, S. Instrumentación de los conductos radiculares. In: BEER, R.; BAUMANN, M. A.; KIM, S. Atlas de Endodoncia. Trad.: Cristina de la Rosa Gay y Eduard Valmaseda Castellón. Barcelona: Masson, S.A., 1998. p. 107-144. 
BENATTI, O.; VALDRIGHI, L. Reparação apical e periapical pós-tratamento endodôntico, decorrente da aplicação do forame apical. (Estudo histopatológico em dentes de cães). Rev Assoc Paul Cir Dent, Chicago, v. 38, n. 6, p. 431-447, Nov./Dez. 1984.

BERGER, C. R. Instrumentos endodônticos de conicidade gradual: nova proposta para o preparo escalonado dos canais radiculares. JBC J Bras Odontol Clin,, Curitiba, v. 1, n. 5, Set./Out. 1997.

BERGER, C. R. Instrumentação Manual do Canal Radicular. In: FELLER, C.; Atualização na Clínica Odontológica. Recursos Antagônicos. $19^{\circ} \mathrm{CIOSP}$ (Congresso Internacional de Odontologia de São Paulo). São Paulo. São Paulo: Artes Médicas, 2000. p. 168-247.

BIER, O. Resumo histórico. In: BIER, O. Microbiologia e Imunologia. 30ed. São Paulo: Melhoramentos, 1990. p. 3-15.

BOLANOS, O. R.; JENSEN, J. R. Scanning electron microscope comparisons of the efficacy of various methods of root canal preparation. $\mathbf{J}$ Endod, Chicago, v. 6, n. 11, p. 815-822, Nov. 1980.

BOMBANA, A. C. Análise Química (Quantitativa) das ligas de Aço Inoxidável de alguns instrumentos endodônticos de diferentes tipos e procedências - Contribuição ao estudo. 1985. 75f. Tese (Doutorado em 
Endodontia) - Faculdade de Odontologia, Universidade de São Paulo, São Paulo.

BRAMANTE, C. M.; BERBERT, A.; BORGES, R. P. A methodology for evaluation of root canal instrumentation, J Endod, Chicago, v. 13, n. 5, p. 243-245, May 1987.

BRANTLEY, W. A.; LUEBKE, N.H.; LUEBKE, F. L.; MITCHELL, J. C. Performance of engine-driven rotary endodontic instruments with a superimposed bending deflection: V. Gates Glidden and Peeso drills. J Endod, Chicago, v. 20, n. 5, p. 241-245, May 1994.

BRYANT, S. T.; THOMPSON, S. A.; AL-OMARI, M. A., DUMMER, P. M. Shaping ability of ProFile rotary nickel-titanium instruments with ISO sized tipos in simulated canals: Part 1. Int Endod J, Oxford, v. 31, n. 4, p. 275-281, Jul. 1998a.

BRYANT, S. T.; THOMPSON, S. A.; AL-OMARI, M. A., DUMMER, P. M. Shaping ability of ProFile rotary nickel-titanium instruments with ISO sized tipos in simulated canals: Part 2. Int Endod J, Oxford, v. 31, n. 4, p. 282-289, Jul. 1998b.

BRYANT, S. T.; DUMMER, P. M. H.; PITON, C.; BOURBA, M.; MOGHAL. Shaping ability of .04 and .06 taper ProFile rotary nickel-titanium instruments 
in simulated root canals. Int Endod J, Oxford, v. 32, n. 3, p. 155-164. May 1999.

CALDWELLL, J. L. Change in working length following instrumentation of molar canals. Oral Surg Oral Med Oral Pathol, Saint Louis, v. 41, n. 1, p. 114-118, Jan. 1976.

CAMPOS, J. M.; del RIO, C. Comparison of mechanical and standard hand instrumentation techniques in curved root canals. J Endod, Chicago, v. 16, n. 5, p. 230-234, May 1990.

CAMPS, J. J.; PERTOT, W. J. Machining efficiency of nickel-titanium K-type files in a linear motion. Int Endod J, Oxford, v. 28, n. 6, p. 274-284, Nov. 1995.

CANZANI, J. H.; FERNANDEZ, E. G.; TESTA, R.; SANTIA, C.; FUSARO, E.; HERBEL, B. Empleo de la técnica escalonada y el ensanchador mecánico en la preparación de los conductos radiculares. Rev Asoc Odont Arg, Buenos Aires, v. 72, n. 2, p. 40-42, May. 1984.

CHEUNG, G. S. P.; CHAN, A. W. K. An in vitro comparison of the Excalibur handpiece and hand instrumentation in curved root canals. J Endod, Chicago, v. 22, n. 3, p. 131-134, Mar. 1996a. 
CHEUNG, G. S. P.; CHAN, A. W. K. A comparison of stainless steel and nickel-titanium K-files in curved root canals. Int Endod J, Oxford, v. 29, n. 6, p. 370-375, Nov. 1996b.

CLEM, W.H. Endodontics: the aldolescent patient. Dent Clin North Am, Philadelphia, v. 13, n. 2, p. 483-493, Apr. 1969.

COFFAE, K. P.; BRILLIANT, J. D. The effect of serial preparation versus nonserial preparation on tissue removal in the root canals of extracted mandibular humam molars. J Endod, Chicago, v. 1, n. 6, p. 211-215, Jun. 1975.

COUNCIL ON DENTAL MATERIALS AND DEVICES OF THE AMERICAN DENTAL ASSOCIATION. New American Dental Association Specification No 28 for Endodontic Files and Reamers. J Am Dent Assoc, Chicago, v. 93, p. 813-817, Oct. 1976.

COUNCIL ON DENTAL MATERIALS AND DEVICES OF THE AMERICAN DENTAL ASSOCIATION. New American Dental Association Specification $N^{\circ}$ 29 General Specification for hand instruments. J Am Dent Assoc, Chicago, v. 93 , p. $818-823$, Oct. 1976.

CURTI Jr., A.; COLLESI, J. P. P.; KIYOHARA, P. K.; FICHMAN, D. M. Estudo morfológico de instrumentos endodônticos através de microscopia 
eletrônica de varrredura. Rev Assoc Paul Cir Dent, São Paulo, Ano II, v. 3, p. 42-51, Mai./Jun. 1980.

CYMERMAN, J. J.; JEROME, L. A.; MOODNIK, R. M. A scanning electron microscope study comparing the efficacy of hand instrumentation with ultrasonic instrumentation of the root canal. J Endod, Chicago, v. 9, n. 8, p.3 27-331, Aug. 1983.

DAVIS, B. D.; DULBECCO, R.; EISEN, H. N.; GINSBERG, H. S.; WOOD Jr., W. B. Evolution of microbes and of Microbiology. In: DAVIS, B. D.; DULBECCO, R.; EISEN, H. N.; GINSBERG, H. S.; WOOD Jr., W. B. Microbiology. 2ed. Hargerstown: Harper \& Row, Publishers, Inc., 1973. p. 117.

DE DEUS, Q. D. Endodontia. Conceituação. Breve resenha histórica. In: DE DEUS, Q. D. Endodontia. 4ed. Rio de Janeiro: MEDSI, 1986. p. 01-09.

DIETSCHI, J. M.; DIETSCHI, D.; KREJCI, I. Nickel-titanium rotary instruments: review and strategy for development of a new instrument. Pract Proced Aesthet Dent, Mahwah, v. 13, n. 5, p. 385-389, Jun-Jul 2001.

ESPOSITO, P. T.; CUNNINGHAM, C. J. A comparison of canal preparation with nickel-titanium and stainless steel instruments. J Endod, Chicago, v. 21, n. 4, p. 173-175, Apr. 1995. 
ESTRELA, C.; PESCE, H. F.; STEFHAN, I. W. Proposição de uma técnica de preparo cervical para canais radiculares curvos. ROBRAC, Goiânia, v. 2, n. 4, p. 21-25, Set. 1992.

EVANS, R. T. Oral Infection and Immunity. In: NISENGARD, R. J.; NEWMAN, M. G. Oral Microbiology and Immunology. 2ed. Philadelphia: W. B. Saunders Company, 1994. p. 01-07.

FABRA-CAMPOS, H.; RODRIGUEZ-VALLEJO, J. Digitization, analysis and processing of dental images during root canal preparation with Quantec Series 2000 instruments. Int Endod J, Oxford, v. 34, n. 1, p. 29-39, 2001.

FARINIUK, L. F.; BARATTO-FILHO, F.; GUERISOLI, D. M.; BARBIZAN, J. V.; PECORA, J. D.; SOUSA-NETO, M. D. Modeling capacity of ENDOflash files in simulated root canals. Braz Dent J, Ribeirão Preto, v. 12, n. 1, p. 3942, 2001.

FAVA, L. R. G. Técnicas escalonadas em Endodontia. In: FAVA, L.R.G. Endodontia. Temas de atualização. São Paulo: Livraria Editora Artes Médicas Ltda, 1984. p. 71-96.

FAVA, L. R. G. The double-flared technique: an alternative for biomechanical preparation. J Endod, Chicago, v.9, n.2, p. 76-80, Feb. 1983. 
FELT, R. A.; MOSER, J. B.; HEUER, M. A. Flute design of endodontic instruments: its influence on cutting efficiency. J Endod, Chicago, v. 8, n. 6, p. 253-259, Jun. 1982.

FISH, W. Bone Infection. J Am Dent Assoc, v. 26, n. 5, p. 691-712, May 1939.

FREITAS, A. Conceito, importância e histórico dos raios X. In: FREITAS, A.; ROSA, J.E.; SOUZA, I.F. Radiologia Odontológica. 2ed. São Paulo: Artes Médicas, 1988. p. 3-13.

GAMBARINI, G. Flexibility of Profile Nickel-Titanium Rotary Instruments. J Evolut Dent, Senia, v. 1, n. 2, p. 45-51, Dec. 1998. Disponível em: http://www.dental-smila.com/1998/1-2-1998_contents.htm. Acessado em 23/09/2001

GILLES, J. A.; del RIO, C. E. A comparison of the Canal Master endodontic instrument and K-type files for enlargement of curved root canals. J Endod, Chicago, v. 16, n. 12, p. 561-565, Dec. 1990.

GLICKMAN, G. N.; KOCH, K.AA. $21^{\text {st }}$-century endodontics. J Am Dent Assoc, Chicago, v. 131, art. 4, p. 39S-46S, Jun. 2000. 
GLOSSON, C. R.; HALLER, R. H.; DOVE, B. del RIO, C. E. A comparison of root canal preparations using $\mathrm{Ni}$-Ti hand, $\mathrm{Ni}-\mathrm{Ti}$ engine-driven, and $\mathrm{K}$-flex endodontic instruments. J Endod, Chicago, v. 21, n. 3, p. 146-151, Mar. 1995.

GLUSKIN, A. H.; BROWN, D. C.; BUCHANAN, L. S. A reconstructed computerized tomographic comparison of Ni-Ti rotary GT files versus tradional instruments in canals shaped by novice operators. Int Endod J, Oxford, v. 34, n. 6, p. 476-484, Sep. 2001.

GOERIG, A. C.; MICHELICH, R. J.; SCHULTZ, H. H. Instrumentation of root canals in molar using the step-down technique. J Endod, Chicago, v. 8, n. 12, p. 550-554, Dec. 1982.

GOLDMAN, M.; SAKURAI, E.; KRONMAN, J.; TENCA, J. I. An in vitro study of the pathfinding ability of a new automated handpiece. J Endod, Chicago, v. 13 , n. 9, p. 429-433, Sept. 1987.

GOODMAN, A.; READER, A.; BECK, M.; MELFI, R. An in vitro comparison of the efficacy of the step-back technique versus a step-back/ultrasonic technique in human mandibular molars. J Endod, Chicago, v. 11, n. 6, p. 249-256, Jun. 1985. 
GORDON, R. A. Hipócrates e tudo o mais. GORDON, R.A. A assustadora História da Medicina. 6ed. Trad. Aulyde Soares Rodrigues. Rio de Janeiro: Ediouro, 1996. p. 07-18.

GRIFFITHS, I. T.; BRYANT, S. T.; DUMMER, P. M. Canal shapes produced sequentially during instrumentation with Quantec LX rotary nickel-titanium instruments: a study in simulated canals. Int Endod J., Oxford, v. 33, n. 4, p. 346-354, Jul. 2000.

GRIFFITHS, I. T.; CHASSOT, A. L.; NASCIMENTO, M. F.; BRYANT, S. T.; DUMMER, P. M. Canal shapes produced sequentially during instrumentation with Quantec SC rotary nickel-titanium instruments: a study in simulated canals. Int Endod J., Oxford, v. 34, n. 2, p. 107-112, Mar. 2001.

GUERISOLI, D. M. Z.; SOUZA NETO, M. D.; PÉCORA, J. D. Mecanismo de ação dos instrumentos rotatórios em níquel-titânio. Ribeirão Preto: Departamento de Odontologia Restauradora da Faculdade de Odontologia de Ribeirão Preto da Universidade de São Paulo, 1999. Disponível em: http://www.forp.usp.br/restauradora/rotatorios/rotary/resumo.htm. Acesso em: 21 mar. 2001.

GULLICKSON, D. C.; MONTGOMERY, S. The study of root canal morphology using a digital image processing technique. J Endod, Chicago, v. 13, n. 4, p. 158-163, Apr. 1987. 
HAIKEL, Y.; ALLEMANN, C. Effectiveness of four methods for preparing root canals: a scanning electron microscopic evaluation. J Endod, Chicago, v. 14, n. 7, p. 340-345, Jul. 1988.

HARLAN, A.; NICHOLLS, J.; STEINER, J. A comparison of curved canal instrumentation using nickel-titanium or stainless steel files with the Balanced-Forece Technique. J Endod, Chicago, v. 22, n. 8, 1996

HUNTER, W. The rôle of Sepsis and of Antisepsis in Medicine. Dent Cosmos, v. 60, n. 7, p. 585-602, Jul. 1918.

INGLE, J. I. A standardized endodontic technique utilizing newly designed instruments and filling materials. Oral Surg Oral Med Oral Path, Saint Louis, v. 11 , n. 1, p. 83-91, Jan. 1961.

INGLE, J. I.; BEVERIDGE, E. E.; GLICK, D. HL; WEICHMAN, J. A. Modern endodontic therapy. In: INGLE, J. I.; BAKLAND, L. K. Endodontics. 4ed. Pensylvania: Williams \& Wilkins, 1994. p. 01-52.

ISOM, T. L.; MARSHALL, J. G.; BAUMGARTNER, J. C. Evaluation of root thickness in curved canals after flaring. J Endod, Chicago, v. 21, n. 7, p. 368-371, Jul. 1995. 
JUNGMANN, C. L.; UCHIN, R. A.; BUCHER, J.F. Effect of instrumentation on the shape of the root canal. J Endod, Chicago, v. 1, n. 2, p. 66-69, Feb. 1975.

KESSLER, J. R.; PETERS, D. D.; LORTON, L. Comparison of the relative risk of molar root perforations using various endodontic instrumentation techniques. J Endod, Chicago, v. 9, n. 10, p. 439-447, Oct. 1983.

KLAYMAN, S. M.; BRILLIANT, J. D. A comparison of the efficacy of serial preparation versus Giromatic preparation. J Endod, Chicago, v. 1, n. 10, p. 334-337, Oct. 1975.

KUM, K-Y; SPANGBERG, L.; CHA, B. Y.; II-YOUNG, J.; SEUNG-HONG, L.; CHAN-YOUNG, L. Shaping ability of three ProFile rotary instrumentaion techniques in simulated resin root canals. J Endod, Chicago, v. 26, n. 12, p. 719-723, Dec. 2000.

LANGELAND, K.; LIAO, K. (K. S.); PASCON, E. . Work-saving devices in endodontics: efficacy of sonic and ultrasonic techniques. J Endod, Chicago, v. 11, n. 11, p. 499-510, Nov. 1985.

LEEB, J. Canal orifice enlargement as related to biomechanical preparation. J Endod, Chicago, v. 9, n. 11, p. 463-470, Nov. 1983. 
LEONARDO, M. R. Endodontia: Tratamento de Canais Radiculares. Evolução através da história. In: LEONARDO, M. R.; LEAL, J. M.

Endodontia. Tratamento de Canais Radiculares. 2ed. São Paulo: Panamericana, 1991. p. 01-18.

LÉVY, G. Une nouvelle instrumentation pour réaliser mécaniquement l'ensemble de la procédure endodontique: le Canal Finder. ENDO, Paris, v. 3, n. 2, p. 11-18, Jui. 1984.

LÉVY, G. Obturation canalaire avec Canal Finder System sur canaux courbes. Chir Dent de Fr, Paris, v. 57, n. 399, p. 41-45, Oct. 1987.

LÉVY, G. Le Canal Finder System 89!!! Améliorations et indications après quatre années d'experimentation et d'utilization. Rev Odontostomatol (Paris), Paris, v. 19, n. 4, p. 327-336, Jui./Agu. 1990.

LIM, K. C.; WEBBER, J. The validity of simulated root canals for the investigation of the prepared root canal shape. Int Endod J, Oxford, v. 18, n. 4, p. 240-246, Oct. 1985.

LIM, S. S.; STOCK, J. R. The risk of perforation in the curved canal: anticurvature filing compared with the Stepback Technique. Int Endod J, Oxford, v. 20, n. 1, p. 33-39, Jan. 1987. 
LOPES, H. P.; COSTA FILHO, A. S. Contribuição para o estudo de uma variação de técnica no preparo biomecânico dos canais radiculares, utilizando-se as brocas de Gates e de Largo. RBO, Rio de Janeiro, v. 47, n. 6, p. 16-22, Nov./Dez. 1990.

LOPES, H. P.; AGUIAR, T. R. S. Instrumentos manuais x rotatórios. RGO, Porto Alegre, v. 42, n. 4, p. 195-198, Jul./Ago. 1994.

LUEBKE, H. H.; BRANTLEY, W. A. Torsional and metallurgical properties of rotary endodontic instruments. II. Stainless steel Gates Glidden Drills. J Endod, Chicago, v. 17, n. 7, p. 319-323, Jul. 1991.

LUMLEY, K. D. An in vitro evaluation of canal preparation using Profile.04 and .06 taper instruments. End Dent Traumatol, Copenhagen, v. 14, n. 1, p. 16-20, 1998.

MACHADO, M. L. B. B. L. Avaliação in vitro do desgaste dentinário dos terços cervical e médio promovido pela ação de instrumentos rotatórios no preparo químico-cirúrgico de canais radiculares. $138 f$. 2000. Tese (Doutorado em Endodontia) - Faculdade de Odontologia, Universidade de São Paulo, São Paulo. 
MACHADO, M. E. L.; PESCE, H. F. Estudo da região apical de dentes tratados endodonticamente até o vértice radiográfico da raiz. Rev Assoc Paul Cir Dent, São Paulo, v. 35, n. 6, p. 534-537, Nov./Dez. 1981.

MACHADO, M. E. L.; MACHADO, M. L. B. B. L.; ANTONIAZZI, J. H. Eficácia da técnica seriada convencional e das técnicas escalonadas ápico-cervical e cérvico-apical no preparo químico-cirúrgico de canais curvos. RBO, Rio de Janeiro, v. 55, n. 2, p. 72-75, 1998.

MAYER, V. R. Die mechanische Aufbereitung nicht geradliniger Wurzelkanäle einschlieblich ihrer Komplikationsmöglichkeiten unter Verwendung des Instrumentariums Giromatic. D Deut Zahnärz, v. 19, n. 23, p. 766-770, Dec. 1965.

MELO, L. L.; SYDNEY, G. B. Preparo dos canais curvos. RGO, Porto Alegre, v. 38, n. 4, p. 305-308, Jul./Ago. 1990.

MILLER, W. D. An introduction to the study of the bacterio-pathology of the dental pulp. Dent Cosmos, v. XXXVI, n. 7, p. 505-528, Jul. 1894.

MIRANZI, B. A. S. Avaliação "in vitro" das alterações promovidas em canais radiculares artificiais curvos após instrumentação com limas de níque-titânio manuais e acionadas a motor. 1999. 141f. Dissertação 
(Mestrado em Endodontia) - Faculdade de Odontologia, Universidade de São Paulo, Ribeirão Preto.

MOODNIK, R. M.; DORN, S. O.; FELDMAN, M. J. Efficacy of biomechanical instrumentation: a scanning electron microscopic study. J Endod, Chicago, v. 2, n. 9, p. 261-266, Sept. 1976.

MULLANEY, T.P. Instrumentation of finely curved canals. Dent Clin North Am, Philadelphia, v. 23, n. 4, p. 575-592, Oct. 1979.

NEWMAN, J. G.; BRANTLEY, W. A.; GERSTEIN, H. A study of the cutting efficiency of seven brands of endodontic files in linear motion. J Endod, Chicago, v. 9, n. 8, p. 316-322, Aug. 1983.

OTTOSEN, S. R.; NICHOLLS, J. I.; STEINER, J. C. A comparison of instrumentation using Naviflex and Profile nickel-titanium engine-driven rotary instruments. J Endod, Chicago, v. 25, n. 6, p. 457-460, Jun. 1999.

PAIVA, J. G.; ANTONIAZZI, J. H.; COSTA, W. F.; CARLIK, J.; ROMANI, N. F. Fase de preparo do canal radicular. In: PAIVA, J.G.; ANTONIAZZI, J.H. Endodontia. Bases para a prática clínica. 2.ed. São Paulo: Artes Médicas, 1988. p. 531-629. 
PALLOTTA, R. C.; MACHADO, M. E. L.; MACHADO, M. L. B. B. L. Avaliação e comparação do poder de corte das limas Nitiflex e Flexofile em dentes naturais. ECLER Endod, São Paulo, v. 1, n. 3, Sep. 1999.

PÉCORA, J. D.; CAPELLI, A.; BARBIN, E. L.; SEIXAS, F. H. Guia Prático para uso da instrumentação eletromecânica (rotatório) no tratamento dos canais radiculares. Ribeirão Preto: Ribeirão Preto: Departamento de Odontologia Restauradora da Faculdade de Odontologia de Ribeirão Preto da Universidade de São Paulo, 2000. Disponível em: <http://www.forp.usp.br/restauradora/rotatorios/guia/guia_pratico.htm> . Acesso em: 21 mar. 2001.

PESCE, F. H.; MACHADO, M. E. L.; SYDNEY, G. B. Variação da odontometria no preparo de canais curvos. Rev USF, São Paulo, v. 4, n. 1, p. 19-22, 1986.

PETSCHELT, A. Endodontie: Maschinell - manuell? Die Aufbereitung und Spülung des Wurzelkanals. Dtsch Zahnärztl Z, Munich, v. 44, n. 6, p. 407413, Jun. 1989.

PILO, R.; CORCINO, G.; TAMSE, A. Residual dentin thickness in mandibular premolars prepared with hand and rotatory instruments. $\mathbf{J}$ Endod, Chicago, v. 24, n. 6, p. 401-404, Jun. 1998. 
POULSEN, W. B.; DOVE, B. del RIO, C. E. Effect of nickel-titanium enginedriven instrument rotational speed on root canal morphology. J Endod, Chicago, v. 21, n. 12, p.609-612, Dec. 1995.

READER'S DIGEST. As plantas na Medicina. In: READER'S DIGEST, Segredos e virtudes das plantas medicinais. Rio de Janeiro: Reader's Digest Brasil Ltda., 1999. p. 26-55.

REYNOLDS, M. A.; MADISON, S.; WALTON, R. E.; KRELL, K. V.; RITTMAN, R. J. An in vitro histological comparison of the step-back, sonic, and ultrasonic instrumentation techniques in small, curved root canals. $\mathbf{J}$ Endod, Chicago, v. 13, n.7, p. 307-314, Jul. 1987.

RHODES, J. S.; FORD, T. R.; LYNCH, J. A.; LIEPINS, P. J.; CURTIS, R. V. A comparison of two nickel-titanium instrumentation techniques in teeth using microcomputed tomography. Int Endod J, Oxford, v. 33, n. 3, p. 274-285, May 2000.

RING, M. E. The ancient Near East. In: RING, M. E. Dentistry: an illustrated history. St. Louis: Abradale/Mosby, 1985a. p. 27-38.

RING, M. E. The Far East. In: RING, M. E. Dentistry: an illustrated history. St. Louis: Abradale/Mosby, 1985b. p. 73-100. 
RING, M. E. The late middle ages in Western Europe: thirteenth to sixteenth centuries. In: RING, M. E. Dentistry: an illustrated history. St. Louis: Abradale/Mosby, 1985c. p. 101-116.

RING, M. E. The Renasissance. In: RING, M. E. Dentistry: an illustrated history. St. Louis: Abradale/Mosby, 1985d. p. 117-144.

RING, M. E. The eighteenth century in Europe. In: RING, M. E. Dentistry: an illustrated history. St. Louis: Abradale/Mosby, 1985e. p. 157-182.

RING, M. E. The late nineteenth century in the United States and Europe. In: RING, M. E. Dentistry: an illustrated history. St. Louis: Abradale/Mosby, 1985f. p. 229-278.

ROANE, J. B.; SABALA, C. L.; DUNCANSON, M. G. The "Balanced Force" concept for instrumentation of curved canals. J Endod, Chicago, v. 11, n. 5, p. 203-211, May 1985.

ROIG-CAYÓN, M.; BASILIO-MONNÉ, J.; ABÓS-HERRÁNDIZ, R.; BRAUAGUADÉ, E.; CANALDA-SAHLI, C. A comparison of molar root canal preparations using six instruments and instrumentation techniques. J Endod, Chicago, v. 23, n. 6, p. 383-386, Jun. 1997. 
SAUNDERS, W. P.; SAUNDERS, E. M. The heat generated on the external root surface during post space preparation. Int Endod J, Oxford, v. 22, n. 1, p. 169-173, Jul. 1989.

SAUNDERS, W. P.; SAUNDERS, E. M. Comparison of three instruments in the preparation of the curved root canal using the modified double-flared technique. J Endod, v. 20, n. 9, p. 440-444, Sept. 1994.

SCHÄFER, E.; TEPEL, J.; HOPPE, W. Properties of endodontic hand instruments used in rotary motion. Part 2. Instrumentation of curved canals. J Endod, Chicago, v. 21, n. 10, p. 493-497, Oct. 1995.

SCHÄFER, E. Effects of four instrumentation techniques on curved canals: a comparison study. J Endod, Chicago, v. 22, n. 12, p. 685-689, Dec. 1996.

SCHÄFER, E. Root canal instruments for manual use: a review. Endod Dent Traumatol, Copenhagen, v. 13, n. 2, p. 51-64, Apr. 1997.

SCHÄFER, E. Relationship between design features of endodontic instruments and their properties. Part 1. Cutting efficiency. J Endod, Chicago, v. 25, n. 1, p. 52-55, Jan. 1999a. 
SCHÄFER, E. Relationship between design features of endodontic instruments and their properties. Part 2. Instrumentation of curved canals. $\mathbf{J}$ Endod, Chicago, v. 25, n. 1, p. 56-59, Jan. 1999b.

SCHÄFER, E.; ZAPKE, K. A comparative scanning electron microscopic investigation of the efficay of manual and automated instrumentation of root canals. J Endod, Chicago, v. 26, n. 11, p. 660-664, Nov. 2000.

SCHÄFER, E. Shaping ability of Hero 642 rotary nickel-titanium instruments and stainless steel hand K-Flexofiles in simulated root canals. Oral Surg Oral Med Oral Pathol, Saint Louis, v. 92, n. 2, p. 215-200, Aug 2001.

SCHILDER, H. Cleaning and Shaping the root canal. Dent Clin North Am, Philadelphia, v. 18, n. 2, p. 269-296, Apr. 1974.

SCHNEIDER, S. W. A comparison of canal preparations in straight and curved root canals. Oral Surg Oral Med Oral Pathol, Saint Louis, v. 32, n. 2, p. 271-275, Aug. 1971.

SHORT, J. A.; MORGAN, L. A.; BAUMGARTNER, C. A comparison of canal centering ability of four instrmentation techniques. J Endod, Chicago, v. 23, n. 8, p. 503-507, Aug. 1997. 
SPYROPOULOS, S.; ELDEEB, M. E.; MESSER, H. H. The effect of Giromatic files on the preparation shape of severely curved canals. Int Endod J, Oxford, v. 20, n. 3, p. 133-142, May 1987.

STAMOS, D. E.; SADEGHI, E. M.; HAASCH, G. C.; GERSTEIN, H. An in vitro comparison study to quantitate the debridement ability of hand, sonic, and ultrasonic instrumentation. J Endod, v. 13, n. 9, p. 434-440, Sept. 1987.

SUNDQVIST, G. Endodontic Microbiology. In: SPANGBERG, L. S. W. Experimental Endodontics. Florida: CRC Press, 1990. p. 131-153.

SZEP,S; GERHARDT, T.; LEITZBACH, C.; LUDER, W.; HEIDEMANN, D. Preparation of severely curved simulated canals using engine-driven rotary and conventional hand instruments. Clin Oral Investig, Berlin, v. 5, n. 1, p. 17-25, Mar. 2001.

TAYLOR, G. N. Advanced techniques for intracanal preparation and filling in routine endodontic therapy. Dent Clin North Am, Philadelphia, v. 28, n. 4, p. 819-832, Oct. 1984.

TEPEL, J.; SCHÄFER, E.; HOPPE, W. Properties of endodontic hand instruments used in rotary motion. Part 1. Cutting efficiency. J Endod, Chicago, v. 21, n. 8, p. 418-421, Aug. 1995. 
THARUNI, S. L.; PARAMESWARAN, A.; SUKUMARAN, V. G. A comparison of canal preparation using K-file and Lightspeed in resin blocks. J Endod, Chicago, v. 22, n. 9, p. 474-476, Sep. 1996.

THOMPSON, S. A.; DUMMER, P. M. H. Shaping ability of ProFile.04 taper Series 29 rotary nickel-titanium instruments in simulated root canals. Part 1. Int Endod J, Oxford, v. 30, n. 1, p. 1-7, Mar. 1997a.

THOMPSON, S. A.; DUMMER, P. M. H. Shaping ability of Profile.04 taper Series 29 rotary nickel-titanium instruments in simulated root canals. Part 2. Int Endod J, Oxford, v. 30, n. 1, p. 8-15, Mar. 1997b.

THOMPSON, S. A.; DUMMER, P. M. H. Shaping ability of Lightspeed rotary nickel-titanium instruments in simulated root canals. Part 1. J Endod, Chicago, v. 23, n. 11, p. 698-702, Nov. 1997c.

THOMPSON, S. A.; DUMMER, P. M. H. Shaping ability of NT e McXim rotary nickel-titanium instruments in simulated root canals. Part 2 Int Endod J, Oxford, v. 30, n. 4, p. 270-278, Jul. 1997d.

THOMPSON, S. A.; DUMMER, P. M. H. Shaping ability of Mity Roto $360^{\circ}$ and Naviflex rotary nickel-titanium instruments in simulated root canals. Part 1. J Endod, Chicago, v. 24, n. 2, p. 128-134, Feb. 1998a. 
THOMPSON, S. A.; DUMMER, P. M. H. Shaping ability of Mity Roto $360^{\circ}$ and Naviflex rotary nickel-titanium instruments in simulated root canals. Part 2. J Endod, Chicago, v. 24, n. 2, p. 135-142, Feb. 1998 b.

THOMPSON, S. A.; DUMMER, P. M. H. Shaping ability of Quantec 2000 rotary nickel-titanium instruments in simulated root canals: Part 1. Int Endod J, Oxford, v. 31, n. 4, p. 259-267, Jul 1998c.

THOMPSON, S. A.; DUMMER, P. M. H. Shaping ability of Quantec 2000 rotary nickel-titanium instruments in simulated root canals: Part 2. Int Endod J, Oxford, v. 31, n. 4, p. 268-274, Jul 1998d.

THOMPSON, S. A.; DUMMER, P. M. H. Shaping ability of Hero 642 rotary nickel-titanium instruments in simulated root canals: Part 2. Int Endod J, Oxford, v. 33, n. 3, p. 255-261, May 2000.

THOMPSON, S. A. An overview of nickel-titanium alloys used in dentistry. Int Endod J, Oxford, v. 33, n. 4, p. 297-310, Jul. 200.

TUREK, T.; LANGELAND, K. A light microscopic study of the efficacy of the telescopic and the Giromatic preparation of root canals. J Endod, v. 8, n. 10, p. 437-443, Oct. 1982. 
VANSAN, L. P. Estudo comparativo "in vitro" da quantidade de material extruído apicalmente durante a instrumentação dos canais radiculares. 1993. 65f. Tese (Doutorado em Reabilitação Oral) - Faculdade de Odontologia, Universidade de São Paulo, Ribeirão Preto.

VESSEY, R. A. The effect of filing versus reaming on the shape of the prepared root canal. Oral Surg Oral Med Oral Pathol, Saint Louis, v. 27, n. 4, p. 543547, Apr. 1969.

WALIA, H.; BRANTLEY, W. A.; GERSTEIN, H. An initial investigation of the bending and torsional properties of nitinol root canal files. J Endod, Chicago, v. 14 , n. 7 , p. 346-351, Jul. 1988.

WALTON, R. E. Histologic evaluation of different methods of enlarging the pulp canal space. J Endod, Chicago, v. 2, n. 10, p. 304-311, Oct. 1976.

WEINE, F. S.; KELLY, R. F.; LIO, P. J. The effect of preparation procedures on original canal shape and on apical foramen shape. J Endod, Chicago, v. 1, n. 8, p. 255-262, Aug. 1975.

WEINE, F. S.; KELLY, R. F.; BRAY, K. E. Effect of preparation with endodontic handpieces on original canal shape. J Endod, Chicago, v. 2, n. 10, p. 298-303, Oct. 1976. 
WELLER, R. N.; BRADY, J. M.; BERNIER, W. E. Efficacy of ultrasonic cleaning. J Endod, Chicago, v. 6,n. 9, p. 740-743, Sep. 1980.

WILDEY, W. L.; SENIA, E. S. A new root canal instrument and instrumentation technique: a preliminary report. Oral Surg O Med O Pathol, Saint Louis, v. 67, n. 2, p. 198-207, Feb. 1989.

ZMENER, O.; BANEGAS, G. Comparison of three instrumentation techniques in the preparation of simulated curved root canals. Int Endod J, Oxford, v. 29, n. 5, p. 315-319, Sept. 1996. 


\section{GLOSSÁRIO}

$\begin{array}{ll}\text { a priori } & \text { a princípio } \\ \text { animalcules } & \text { animálculo, animal microscópico } \\ \text { contagium vivum } & \text { agentes vivos e contaminantes e transmissíveis ao qual } \\ & \text { Fracastorius denominava genericamente seminaria } \\ & \text { (sementes) } \\ & \text { o deus Mercúrio na Mitologia Romana, com seu caduceu } \\ \text { Esculápio } & \text { com que haveria matado a serpente, também associado à } \\ & \text { cura. } \\ & \text { sementes de Meimendro (planta medicinal da família das } \\ & \text { Solanáceas empregada na produção de poções mágicas } \\ \text { henbane seeds } & \text { pelas bruxas na ldade Média, o mesmo que Hioscíamo e } \\ & \text { Velenho) } \\ \text { prior } & \text { antes }\end{array}$




\section{SUMMARY}

\section{IN VITRO MORPHOMETRIC STUDY OF CERVICAL THIRD DENTIN WEARING IN UPPER MOLAR MESIOBUCCAL ROOTS AFTER PREPARATION WITH IRON BURS AND ROTARY NICKEL-TITANIUM INSTRUMENTS}

Nowadays is common sense among endodontists that in root canal preparation, mainly the curved ones, the crown-down approach enlarging the cervical third prior instrumentation of the apical third regions provides better interaction between the instrument and the canal walls than the conventional methods. Technically it provides an adequate form to achieve the best and predictable results in cleaning and shaping the root canal system. Additionally the most recent nickel-titanium made endodontic instruments more flexible than the stainless steel instruments and the new taper design have been appeared to improve the endodontic panorama. Since the introduction of the nickel-titanium alloy in Endodontics by Walia et al. in 1988 a number of instruments produced by such alloy in conjunction with the engines new generation have brought new perspectives to deal tridimensionally with the still challenger endodontic space. In this study the performance of four different instruments in the root canal cervical third enlargement was evaluated. Four 
experimental groups comprised by ten upper molars mesiobuccal roots each were prepared by either (i) Gates bur, (ii) Largo bur, (iii) Profile ${ }^{\circledR} .04 / .06$ \& Orifice Shapers or (iv) Pow-R ${ }^{\mathrm{TM}}$ Coronal Shapers. Before and after preparation digitally acquired images were evaluated for area changes within both mesial and distal root canal walls. All instruments produced some amount of wear in both walls and the distals have changed more than the mesials in most times probably due an excentric performance of all evaluated instruments. Comparison of root canal walls wearing among the four experimental groups showed no statistically significant differences $(\alpha=5 \%)$ for mesial wall. However, statistically analyze $(\alpha=5 \%)$ showed significant differences between Experimental Group \#1 (Gates-Glidden burs) and Experimental Group \#3 (Profile ${ }^{\circledR} .04 / .06$ \& Orifice Shapers) for distal walls with the first showing greater wearing than the latter. Also, the results showed statistically significant differences between Experimental Group \#4 (Pow- ${ }^{\mathrm{TM}}$ \& Coronal Shapers) and Experimental Group \#3 (Profile ${ }^{\circledR}$ \& Orifice Shapers) for the entire structure i.e. mesial and distal walls with the first showing the greater than the latter wearing. It was concluded that all tested instruments wear so the mesial as the distal root canal walls. Experimental results have showed that in first upper molaras mesiobuccal roots Gates-Glidden bur for distals and Pow-R nickel-titanium instruments for both walls, i.e. the cervical dentin entire structure, are supposed to wear more root canal cervical third dentin than the others instruments which they were compared. 


\section{AUTORIZAÇÃO}

Autorizo a reprodução e/ou divulgação total ou parcial da presente obra, por qualquer meio convencional ou eletrônico, desde que citada a fonte e comunicada, ao autor, a referência bibliográfica em que consta a citação.

Júnio Pereira de Sá

Assinatura

Instituição: Faculdade de Odontologia da Universidade de São Paulo

Local e data: São Paulo, 30 de Outubro de 2002.

Endereço: Avenida Comandante Sampaio, $377-1^{\circ}$

andar - sala 02 - Kilômetro Dezoito - Osasco-SP -

CEP: 0619-010

Fone: (11) 3608-7644

e-mail: maxell47@uol.com.br 


\section{ERRATA}

Página 8, linha 4

Onde se lê:. Num tratado Médico...fez uma divisão.....;

Leia-se:......Num tratado médico.... há uma divisão.... 